\title{
SYNOPTIC SURVEYS OF MAJOR RESERVOIRS IN SOUTH CAROLINA, 1988-1989 (U)
}

\author{
by J.A. Bowers \\ Westinghouse Savannah River Company \\ Savannah River Site \\ Aiken, South Carolina 29808 \\ Other Authors:
}

This paper was prepared in connection with work done under Contract No. DE-AC09-89SR18035 with the U. S. Department of Energy. By acceptance of this paper, the publisher and/or recipient acknowledges the U. S. Government's right to retain a nonexclusive, royalty-free license in and to any copyright covering this paper, along with the right to reproduce and to authorize others to reproduce all or part of the copyrighted paper. 


\section{DISCLAIMER}

This report was prepared as an account of work sponsored by an agency of the United States Government. Neither the United States Government nor any agency thereof, nor any of their employees, makes any warranty, express or implied, or assumes any legal liability or responsibility for the accuracy, completeness, or usefulness of any information, apparatus, product, or process disclosed, or represents that its use would not infringe privately owned rights. Reference herein to any specific commercial product, process, or service by trade name, trademark, manufacturer, or otherwise does not necessarily constitute or imply its endorsement, recommendation, or favoring by the United States Government or any agency thereof. The views and opinions of authors expressed herein do not necessarily state or reflect those of the United States Government or any agency thereof.

This report has been reproduced directly from the best available copy.

Available to DOE and DOE contractors from the Office of Scientific and Technical Information, P.O. Box 62, Oak Ridge, TN 37831; prices available from (615) 576-8401, FTS 626-8401.

Available to the public from the National Technical Information Service, U.S. Department of Commerce, 5285 Port Royal Rd., Springfield, VA 22161. 
WSRC-RP-92-368

SYNOPTIC SURVEYS OF MAJOR RESERVOIRS

IN SOUTH CAROLINA, 1988-1989 (U)

James A. Bowers

Westinghouse Savannah River Company

Savannah River Site

Aiken, SC 29808

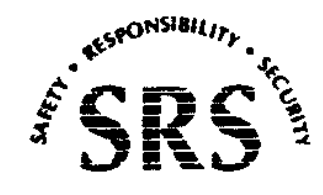

SAVANMAH RIVER SITE 
DBrnare thednon

D. B. Moore-Shedrow, Section Manager

Authorized Derivative Classifier

SYNOPTIC SURVEYS OF MAJOR RESERVOIRS

IN SOUTH CAROLINA, 1988-1989 (U)

James A. Bowers

Darnoou thedear

Approved by D. B. Moore-Shedrow, Section Manager

Publication Date: March, 1992

Westinghouse Savannah River Company

Savannah River Site

Aiken, SC 29808

THIS DOCUMENT WAS PREPARED IN CONNECTION WITH WORK UNDER THE U.S. DEPARTMENT OF ENERGY (CONTRACT DE-AC09-88SR18035). By acceptance of this paper, the publisher and /or recipient acknowledges the U. S.

Government's right to retain a nonexclusive, royalty-free license in and to any copyright covering this paper, along with the right to reproduce and to authorize others to reproduce all or part of the copyrighted paper. 


\section{LIST OF FIGURES}

Figure 1. Location of ten reservoirs in South Carolina.

Figure 2. Means and Standard Errors (SEs) of temperature in Sepember 1988 and 1989.

Figure 3. Means and Standard Errors (SEs) of pH in September 1988 and 1989. 10

Figure 4. Means and Standard Errors (SES) of DO in September 1988 and 1989. 10

Figure 5. Means and Standard Errors (SEs) of conductivity in September 11 1988 and 1989.

Figure 6. Means and Standard Errors (SEs) of chlorophyll $a$ in September 1988 and 1989.

Figure 7. Regression analyses of temperature, $\mathrm{pH}$, conductivity, dissolved oxygen, and chorophyll $a$ results from transect sampling during 1988.

Figure 8. Regression analyses of temperature, $\mathrm{pH}$, conductivity, dissolved oxygen, and chorophyll $a$ results from transect sampling during 1989.

Figure 9. Mean and SE for Secchi depth at 1-meter from 5 stations along the transect in each lake in 1988 and 1989.

Figure 10. Mean and SE for alkalinity at 1-meter from 5 stations along the transect in each lake in 1988 and 1989.

Figure 11. Mean and SE for total phosphorus (TP) at 1-meter from 5 stations along the transect in each lake in 1988 and 1989.

Figure 12. Mean and SE for nitrate and nitrite at 1-meter from 5 stations along the transect in each lake in 1988 and 1989.

Figure 13. Mean and SE for ammonia at 1-meter from 5 stations along the transect in each lake in 1988 and 1989.

Figure 14. Mean and SE for dissolved organic carbon (DOC) at 1-meter from 5 stations along the transect in each lake in 1988 and 1989.

Figure 15. Mean and SE for turbidity at 1-meter from 5 stations along the transect in each lake in 1988.

Figure 16. Dendrogram from Euclidean distance cluster analysis of lakes by conductivity, $\mathrm{pH}$, alkalinity, dissolved organic carbon, total phosphorus, nitrate, nitrite, and ammonia in 1988.

Figure 17. Dendrogram from Euclidean distance cluster analysis of lakes by conductivity, $\mathrm{pH}$, alkalinity, dissolved organic carbon, total phosphorus, nitrate, nitrite, and ammonia in 1989.

Figure 18. Ranking of the ten South Carolina reservoirs according to three EPA trophic indicators during 1988.

Figure 19. Ranking of the ten South Carolina reservoirs according to three EPA trophic indicators during 1989.

Figure 20. Relationship between Secchi disk depth and chlorophyll $a$ in the ten South Carolina reservoirs during 1988.

Figure 21. Relationship between $\log _{10}$ of chlorophyll a versus the $\log _{10}$ of TP 20 in the ten South Carolina reservoirs during 1988.

Figure 22. The vertical distribution of temperature and oxygen during 1988 in L Lake and Lakes Greenwood, Marion, Robinson, and Russell.

Figure 23. The vertical distribution of temperature and oxygen during 1988 in Lakes Monticello, Moultrie, Murray, Par Pond, and Pond B.

Figure 24. The vertical distribution of temperature and oxygen during 1989 in L Lake and Lakes Greenwood, Marion, Robinson, and Russell. 


\section{LIST OF FIGURES}

Figure 25. The vertical distribution of temperature and oxygen during 1989 in Lakes Monticello, Moultrie, Murray, Par Pond, and Pond B.

Figure 26. The vertical distribution of photosynthetic active radiation (PAR) in all of the reservoirs during 1988.

Figure 27. The vertical distribution of photosynthetic active radiation (PAR) in all of the reservoirs during 1989.

Figure 28. The vertical distribution of total phosphorus (TP) and orthophosphate (PO4) in Lake Greenwood, L Lake, and Lakes Marion, Monticello, and Moultrie during 1988.

Figure 29. The vertical distribution of total phosphorus (TP) and orthophosphate $\left(\mathrm{PO}_{4}\right)$ in Lake Murray, Par Pond, Pond B, Lake Robinson, and Lake Russell during 1988.

Figure 30. The vertical distribution of total phosphorus (TP) and orthophosphate (PO4) in Lake Greenwood, L Lake, and Lakes Marion, Monticello, and Moultrie during 1989.

Figure 31. The vertical distribution of total phosphorus (TP) and orthophosphate (PO4) in Lake Murray, Par Pond, Pond B, Lake Robinson, and Lake Russell during 1989.

Figure 32. Phytoplankton species richness (number of species) in the ten reservoirs during 1988 and 1989.

Figure 33. Total cell densities of phytoplankton in the ten reservoirs during 1988 and 1989.

Figure 34. Comparison of total and blue-green densities of algae in the ten reservoirs during 1988.

Figure 35. Comparison of total and blue-green densities of algae in the ten reservoirs during 1989.

Figure 36. Protozoan and Rotifer species richness (number of species) in the ten reservoirs during 1988.

Figure 37. Total Protozoan and Rotifer densities in the ten reservoirs during 1988.

Figure 38. Macrozooplankton species richness (number of species) in the ten reservoirs during 1988 and 1989.

Figure 39. Comparison of total macrozooplankton and Cladocera densities $\quad 35$ during 1988 and 1989.

Figure 40. Relationship between Cladoceran abundances and blue-green 36 densities in the ten reservoirs during 1988.

Figure 41. Relationship between Cladoceran abundances and blue-green 36 densities in the ten reservoirs during 1989.

Figure 42. Benthic taxa richness (number of species) in the ten reservoirs 37 during 1988 and 1989.

Figure 43. Total macroinvertebrate densities and per cent abundance of 38 Oligochaeta, Chaoborus, and Chironomini during 1988.

Figure 44. Total macroinvertebrate densities and per cent abundance of Oligochaeta, Chaoborus, and Chironomini during 1989. 


\section{LIST OF TABLES}

Table 1. Physical characteristics of reservoirs sampled in South Carolina.

Table 2. Land use of drainage areas of reservoirs located outside of Savannah River Site. 


\section{EXECUTIVE SUMMARY}

A Regional Lakes Study in South Carolina was performed to characterize and compare selected reservoirs with regard to water quality, trophic status, and community structure. Synoptic samples were collected at L Lake, Par Pond, and Pond B, Savannah River Site, and at Lakes Greenwood, Marion, Monticello, Moultrie, Murray, Robinson, and Russell during 14-day periods of September 1988 and 1989, a period of maximum thermal stratification.

Fifty-station transect samples for water quality indicated that horizontal variation within any basin was relatively small compared to between lake differences. Multivariate correlation and cluster analysis indicated several affinities between lakes. Pond B and Lake Robinson were very similar with respect to water quality, while Lake Marion, L Lake, Lake Greenwood, Lake Moultrie, and Lake Russell were similar in nutrient status. Lake Marion was unique having very high nitrogen concentrations. Discrete depth sampling for water chemistry resulted in profiles from all 10 lakes that were characteristic of eutrophic systems having pronounced anoxic hypolimnia and a consequent reduced chemical environment.

Trophic indices, developed by the USEPA, gave mixed results depending on the chosen index. Lakes Marion, Greenwood, and L Lake were more eutrophic in status with Lakes Murray and Robinson being classified as oligo/mesotrophic. None of the sampled basins could be considered as an oligotrophic lake.

Phytoplankton populations were similar in all lakes having high cell densities. With the exception of Lakes Robinson and Murray all lakes had significant blue-green algal populations. The absence of large-sized zooplankton species was indicative of intense planktivorous fish predation and regional species ranges. Benthic populations were the most variable between lakes. High concentrations of pelagic protozoans and Rotifera indicated the productive nature of all of the lakes' offshore communities. L Lake and Lake Greenwood had high percentages of chironomids with oligochaete worms dominating the benthos of Lakes Monticello and Moultrie. Par Pond and Pond B contained large populations of Chaoborus. There were no significant differences in numbers of species for phytoplankton, zooplankton, and benthic macroinvertebrates between all of the basins. 


\title{
SYNOPTIC SURVEYS OF MAJOR RESERVOIRS IN SOUTH CAROLINA, 1988-1989 (U)
}

\author{
By James A. Bowers \\ Westinghouse Savannah River Company \\ Savannah River Site \\ Aiken, SC 29808
}

\begin{abstract}
Comprehensive synoptic surveys of ten South Carolina reservoirs (L Lake, Savannah River Site (SRS), Par Pond, SRS, Pond B, SRS, Lake Moultrie, Lake Marion, Lake Murray, Lake Monticello, Lake Robinson, Lake Richard B. Russell, and Lake Greenwood) were performed to characterize and compare these basins with regard to water quality, trophic status, and community structure during September 1988 and September 1989. All of the reservoirs were mesoeutrophic to eutrophic having significantly greater productivity rates than oligotrophic ecosystems.
\end{abstract}

\section{INTRODUCTION}

Synoptic limnological surveys of lakes and reservoirs were initiated at the beginnings of the discipline by Birge and Juday in Wisconsin (Mortimer 1974). Since these beginnings these surveys addressed lake classification (Hutchinson 1957), trophic status (Beeton 1965), the biogeography of aquatic biota (Hutchinson 1967). and most recently regional impacts by such large scale anthropogenic stresses such as phosphorus and nitrogen loading (EPA 1975). Environmental legislation, requiring compliance to specified physical, chemical, and biotic standards, has also been the impetus for lake surveys, including the Clean Water Act (Public Law 92-500).

Section 316a of this legislation, which governs thermal impacts on limnetic communities, has often required that Biological Balanced (Indigenous) Communities (BBCs) populate the impacted lakes. The United States Environmental Protection Agency's (USEPA) guidelines (EPA 1977) that specify four generally accepted criteria for compliance. Communities satisfying the law are: 1) not dominated by pollution (thermally) tolerant species, 2) have biotic diversity and productivity characteristic of that found in other lakes and streams of the region, 3) have populations that are reproducing and are not maintained by repeated stocking and reseeding, and 4) have all trophic groups that would be expected in an ecosystem of that type. However, the above definitions and other more specific portions of the USEPA guidelines are difficult to define and interpret for reservoir communities in the southeastem United States. These reservoirs are very different from the natural lakes that historically served for the USEPA's guidelines, especially Pliestocene glacial lakes from the Midwest and northeastern U.S. (Baxter 1977; Thornton et al. 1981; Kennedy et al. 1985; Kimmel and Groeger 1986). Additionally, limnological and ecological thought current in 1977, still define these USEPA guidelines. Significant advances have been accomplished in the past 15 years concerning physical modelling (Steele 1989), trophic dynamics and community ecology (Carpenter and Kitchell 1984; Carpenter et al. 1987), and the study of stressed ecosystems (Odum 1985; Schindler 1989).

Furthermore, the USEPA guidelines do not specifically address the significant regional differences due to latitude. For example, northern lakes and impoundments experience summer maximum temperatures in the range of $18^{\circ}$ to $25^{\circ} \mathrm{C}$, while reservoirs in southeastern United States often have surface temperatures exceeding $32.5^{\circ} \mathrm{C}$, the regulatory lethal limit for fish. Furthermore, most published studies have characterized the limnology of southeastern reservoirs in terms of water quality and trophic status without comprehensive biotic comparisons relating to $\mathrm{BBC}$ criteria (Kimsey et al. 1982; Ellers et al. 1988; Reckhow 1988; Beaver and Crisman 1990, 1991).

The purpose of this study was to survey 10 South Carolina reservoirs in the Atlantic Coastal Plain and Southern Piedmont area with regard to trophic status, community structure, and BBC criteria. The study made every effort to provide continuity with regard to field and laboratory personnel, sampling protocols, laboratory methods, and processing of biological samples. The results of two 14-day synoptic surveys performed during September 1988 and 1989 are reported here. 


\section{METHODS AND MATERIALS}

\section{General characteristics of reservoirs}

The study sampled 10 South Carolina reservoirs, L Lake, Savannah River Site (SRS), Par Pond, SRS, Pond B, SRS, Lake Moultrie, Lake Marion, Lake Murray, Lake' Monticello, Lake Robinson, Lake Richard B. Russell, and Lake Greenwood (Figure 1). Nuclear power or production reactors or fossil electric generating plants are present on all of the lakes. Physical descriptions of the reservoirs and their drainage areas are listed in Tables 1 and 2.

Par Pond, Pond B, and L Lake, located at the Department of Energy's Savannah River Site, have different histories than the other South Carolina basins. Most importantly, no public access is permitted on these lakes that significantly reduces two common types of environmental impacts on public waters, point-source loadings from large-scale industrial facilities and intense fishing. Pollutants from public drainage basins only enter SRS reservoirs from the pumping of Savannah River water. Furthermore, the lack of any commercial or sport fishery significantly reduces fish mortality. Yet, like all reservoirs in the United States, they were constructed for a specific use, in this case cooling for nuclear production reactors. L Lake was built in 1985 as a once-through cooling reservoir for the L-Reactor. During reactor operations, surface water was pumped from the Savannah River to L Reactor where it passed through heat exchangers before being discharged into the upper reaches of $L$ Lake. At times, water temperatures within the reactor's effluent discharge canal exceeded $70^{\circ} \mathrm{C}$. L Lake has experienced the classic trophic upsurge during the first year of the lake's existence, and is now experiencing trophic decline. Thermal and nutrient loadings and succession changes typical of new reservoirs have shaped the basins history. Significant phosphorus loading often created nitrogen limitation of algal production.

Pond B, built in 1958 with Par Pond, served as a precooler impoundment for R Reactor from 1958 to 1964. The reservoir has not been used as a cooling basin since then, and has experienced an isolated trophic succession.

Par Pond was constructed in 1958 along Lower Three Runs Creek, SRS to serve as a recycling cooling reservoir for $\mathrm{P}$ Reactor. This large (1012 ha) and well studied (Wilde 1985) basin has experienced moderate loadings of nutrients from the Savannah River as makeup water and thermal inputs from P-Reactor operations.
Lake Greenwood and its $2000 \mathrm{~km}^{2}$ watershed (up to Saluda Lake Reservoir) are located within the Southern Piedmont Land Resources Area. The dam, built as part of a hydroelectric project by Duke Power Company, was completed in 1940. Forests and croplands/pasturelands (44.1\% and $32.4 \%$, respectively) dominate land use within the lake's drainage area. Lake Greenwood is currently silting in at an approximate rate of $222 \times 10^{3}$ $\mathrm{m}^{3}$ per year. Contributing to this siltation problem is the periodic opening of silt gates at upstream Boyd Mill Pond. Point and nonpoint pollutants from the urbanized areas of Greenville and Greenwood are thought to significantly impact this lake (Kimsey et al. 1982). The South Carolina Clean Lakes Survey classified Lake Greenwood as eutrophic and nitrogen limited. Upstream point-source discharges have significantly impacted the hypereutrophic Reedy River arm of Lake Greenwood (Kimsey et al., 1982).

Monticello Reservoir is also situated within the Southem Piedmont Land Resources Area. The South Carolina Electric \& Gas Company constructed this waterbody in 1978 to serve as a cooling lake for the Virgil C. Summer Nuclear Station and also as the upper reservoir for the Fairfield Pumped Storage Facility. Pumping water from the Broad River maintains operating levels within the reservoir (Dames \& Moore 1985).

The reservoir's watershed is extremely small $\left(44 \mathrm{~km}^{2}\right)$ and contributes little drainage to the lake. The basin occupies approximately $90 \%$ of its own watershed. Seventy percent $(70 \%)$ of the land within the drainage area is forested. The South Carolina Clean Lakes Survey classified Monticello Reservoir as eutrophic and generally phosphorus limited (Kimsey et al. 1982).

Lakes Marion and Moultrie, collectively known as the Santee-Cooper Lake System, are large, shallow, interconnected reservoirs located in the Atlantic Coastal Plain Land Resources Area. The lakes are situated in the southeastern terminus of the Santee-Cooper River Basin, the second largest river basin on the eastern seaboard (Kimsey et al. 1982). The Santee Cooper lakes, owned by the South Carolina Public Service Authority, were formed in 1941 by impoundment of the Santee River and are operated as multi-purpose reservoirs (hydroelectric generation, recreation, and flood control). These lakes possess a combined drainage area of 38,215 $\mathrm{km}^{2}$. Included in this drainage area are the urban areas of Charlotte, N.C.-Rock Hill, S.C.; GreenvilleSpartanburg, S.C.; and Columbia, S.C. The Congaree and Wateree rivers contribute $96.4 \%$ to the total flow into these reservoirs. The remaining $3.6 \%$ is derived from minor tributaries and immediate surface drainage. Major land uses within this lake system's drainage area include agriculture and forestry (58\%), water and wetlands (33\%), and urban uses (9\%) (SCDHEC-208 


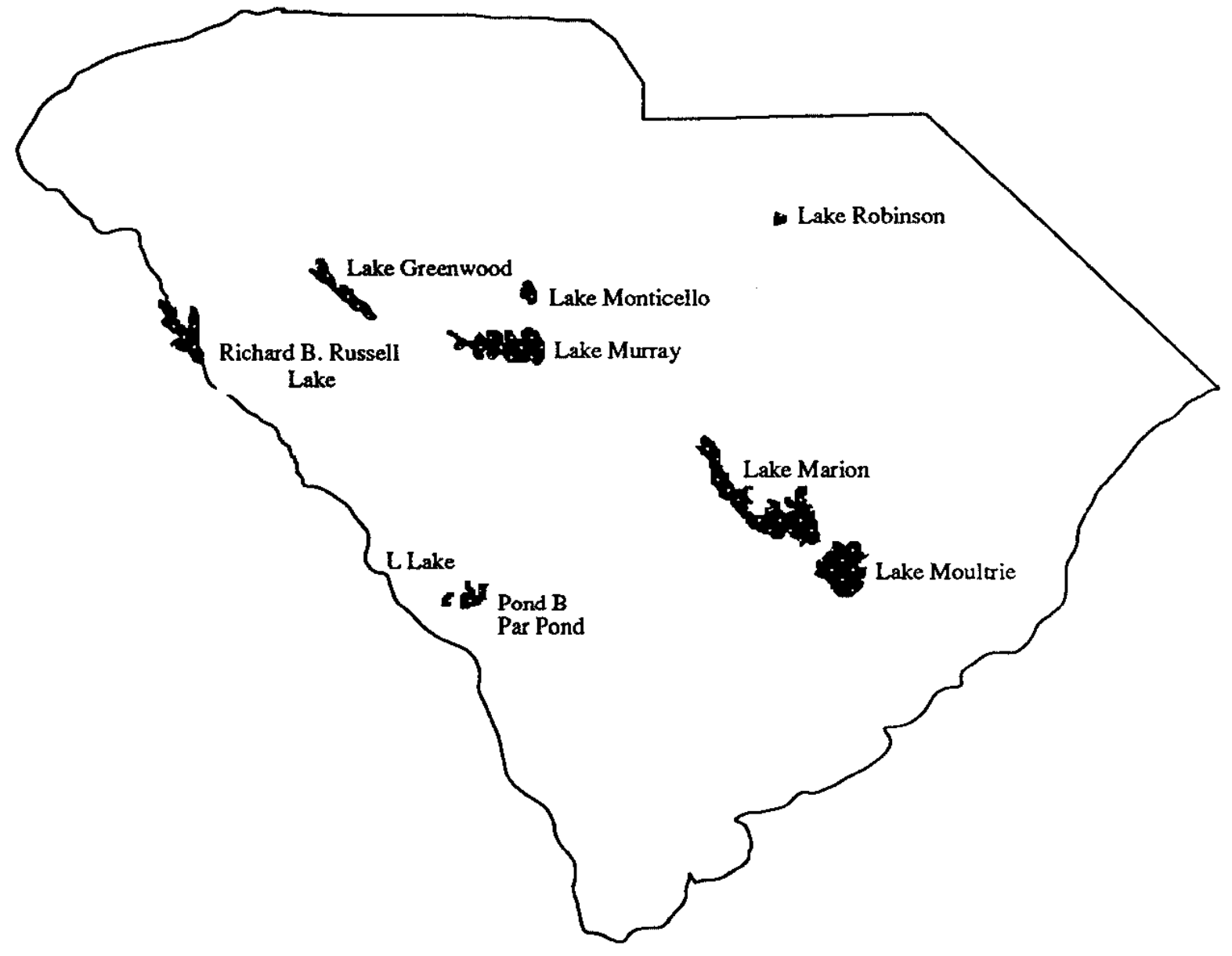

Figure 1. Location of ten reservoirs in South Carolina. 


\begin{tabular}{|c|c|c|c|c|c|c|c|c|}
\hline \multirow[b]{2}{*}{ Reservoir } & & Depth & $\begin{array}{l}\text { Mean } \\
\text { Depth }\end{array}$ & $\begin{array}{l}\text { Surface } \\
\text { Shoreline }\end{array}$ & & $\begin{array}{l}\text { Residence } \\
\text { Time }\end{array}$ & $\begin{array}{l}\text { Shoreline } \\
\text { Length }\end{array}$ & $\begin{array}{c}\text { Drainage } \\
\text { Area }\end{array}$ \\
\hline & $\begin{array}{c}\text { Physiographic } \\
\text { Province }\end{array}$ & $\begin{array}{l}\text { Depth } \\
\text { (m) }\end{array}$ & $\begin{array}{l}\text { Depth } \\
(\mathrm{m})\end{array}$ & $\begin{array}{l}\text { Area } \\
\text { Development } \\
(\mathrm{sq} \mathrm{km}) \\
\text { Ratio }\end{array}$ & $\begin{array}{c}\text { Volume } \\
\left(\mathrm{x} 10^{* * 8} \mathrm{cu} \mathrm{m}\right)\end{array}$ & $\begin{array}{l}\text { Time } \\
\text { (days) }\end{array}$ & $\begin{array}{l}\text { Length } \\
(\mathrm{km})\end{array}$ & $\begin{array}{c}\text { Area } \\
(\times 10 * * 3 \mathrm{sq} \mathrm{km})\end{array}$ \\
\hline Greenwood (1) & Piedmont & 21 & 7 & 46.1 & 3.2 & 82 & 341 & 2 \\
\hline Marion (2) & Coastal Plain & 23.4 & 3.9 & $\begin{array}{r}447.6 \\
7.06\end{array}$ & 15.48 & $31-51$ & 529.6 & 25.43 \\
\hline Monticello (3) & Piedmont & 38.4 & 17.9 & 39.6 & 4.93 & - & - & 0.044 \\
\hline Moultrie (2) & Coastal Plain & 23 & 5.7 & $\begin{array}{l}263 \\
2.9\end{array}$ & 13.13 & $34-62$ & 160.9 & 38.21 \\
\hline Murray (4) & Piedmont & 57.8 & 12.6 & $\begin{array}{c}205.6 \\
\quad 17.7\end{array}$ & 26.08 & 357 & 844 & 5.86 \\
\hline Robinson (5) & Coastal Plain & 9.4 & 4.2 & 9.11 & 0.38 & $37-131$ & - & 0.45 \\
\hline Russell (6) & Piedmont & 47 & 12 & $\begin{array}{r}107.9 \\
24.5\end{array}$ & 12.71 & 102 & 885 & 2.1 \\
\hline LLake (7) & Coastal Plain & 19.8 & 8 & $\begin{array}{c}4.2 \\
0.3\end{array}$ & 0.31 & $14-33$ & 2.1 & - \\
\hline Par Pond (8) & Coastal Plain & 18 & 6.2 & $\begin{array}{r}10.12 \\
4.7\end{array}$ & 0.62 & 108.8 & 53 & 0.093 \\
\hline Pond B (8) & Coastal Plain & 12 & 4.2 & $\begin{array}{r}0.81 \\
2\end{array}$ & 0.034 & - & 6.4 & - \\
\hline $\begin{array}{l}\text { (1) Rodriguez (19) } \\
\text { (2) Inabinet (1985 } \\
\text { (3) Kemsey et al } \\
\text { (4) Daniel (1984); }\end{array}$ & $\begin{array}{l}\text { Wilda (1986); Kimsey } \\
\text { ckett \& Harvey (1987) } \\
\text { ironmental Research }\end{array}$ & $\begin{array}{l}(1982) . \\
\text { (1972) }\end{array}$ & & & (7) $\mathrm{Per}$ & $\begin{array}{r}\text { (5) Kem } \\
\text { (6) Jam } \\
\text { nal communi } \\
\text { (8) Palle }\end{array}$ & $\begin{array}{l}\text { sey et al (1982) } \\
\text { ees et al (1985) } \\
\text { cation with Jim B } \\
\text { er \& Saul (1985) }\end{array}$ & wers, SRL. \\
\hline
\end{tabular}


Table 2. Land Use in Drainage Areas of Offsite Reservoirs

\begin{tabular}{|c|c|c|c|c|c|c|c|}
\hline Reservoir* & $\begin{array}{c}\text { Area } \\
\text { (sq. km) }\end{array}$ & $\begin{array}{l}\text { Agriculture } \\
(\%)\end{array}$ & $\begin{array}{l}\text { Forest } \\
(\%)\end{array}$ & $\begin{array}{c}\text { Wetlands } \\
(\%)\end{array}$ & $\begin{array}{l}\text { Water } \\
(\%)\end{array}$ & $\begin{array}{l}\text { Urban } \\
(\%)\end{array}$ & $\begin{array}{l}\text { Other** } \\
\text { (\%) }\end{array}$ \\
\hline Greenwood & 1999.50 & 32.4 & 44.1 & 4.1 & 2.3 & 15.2 & 1.5 \\
\hline Marion & 14540.30 & 24.7 & 56 & 3.8 & 2.8 & 11.2 & 1.5 \\
\hline Monticello & 44.00 & 20 & 70 & 0 & 2 & 8 & 0 \\
\hline Moultrie & 306.90 & 4.6 & 8.9 & 13.8 & 70.7 & 2 & 0 \\
\hline Murray & 3059.60 & 34.6 & 44.9 & 7.4 & 5.2 & 7.9 & 0 \\
\hline Robinson & $448.10^{\circ}$ & 42.5 & 54.1 & 1.4 & 1.5 & 0.5 & 0 \\
\hline Russell & 2100.00 & 40 & 60 & 0 & 0 & 0 & 0 \\
\hline
\end{tabular}


1980).

Lake Marion, occupies the relatively level floodplain of the Santee River, largest reservoir in the Santee-Cooper River Basin, just below the confluence of the Congaree and Wateree rivers. Hydraulic retention-time estimates range from 31 to 51 days. Intensive agricultural land use along local tributaries contributes approximately 722,000 tons of sediment load to Lake Marion each year (Patterson and Cooney 1986). This sediment load reduces storage capacity and sustains extensive macrophyte beds (approximately 30,000 acres) within Lake Marion's sheltered areas (SCDHEC 1981). The urban areas of Columbia and Camden contribute significant point and nonpoint source pollution through the Congaree and Wateree rivers. Water is discharged from Lake Marion, through a diversion canal, into Lake Moultrie. Lake Marion serves as a significant sediment and nutrient trap for downstream Lake Moultrie:

Lake Moultrie receives approximately $99 \%$ of its inflow from upstream Lake Marion. Surface drainage from contiguous land areas is restricted due to the presence of earthen dams that form approximately two-thirds of Moultrie's perimeter. This waterbody is semicircular in shape having estimated hydraulic retention-times from 34 to 62 days.

Previous surveys of this lake system have found it to be phosphorus limited (EPA 1976; Inabinet 1978). The South Carolina Clean Lakes Survey classified Lakes Marion and Moultrie as eutrophic. The lakes were generally phosphorus limited during the fall, winter, and summer seasons, while nitrogen limited algal production during the spring (Kimsey et al. 1982). Both lakes have extremely brief, weak periods of thermal stratification due to strong flow patterns and short hydraulic retention- times.

Lake Murray and it's $3050 \mathrm{~km}^{2}$ watershed (up to the Lake Greenwood dam) are located within the Southern Piedmont Land Resources Area. Major tributaries to dendritic Lake Murray include the Saluda River (71.34\% of inflow), Bush River (4.94\%), Little Saluda River (4.65\%), and Clouds Creek (3.91\%). The South Carolina Electric and Gas Company (SCE\&G) operates Lake Murray as the site for its Saluda Hydro and McMeekins coal-powered steam generating plants. Cooling waters from the McMeekins plant are discharged alternately into Lake Murray (63\% of time) and the Saluda River (37\% of time) with insignificant thermal impact. The lake also serves as a major recreational facility and drinking water source for the Columbia metropolitan area. Forests and croplands dominate the lake's drainage area $(44.9 \%$ and $34.6 \%$, respectively). Intense shoreline development and urbanization within the immediate drainage area have adversely affected lake water quality, particularly in shallow cove areas.

Lake Murray is estimated to be trapping approximately $469,000 \mathrm{~m}^{3}$ of sediment each year $(0.02 \%$ of its total storage capacity). This siltation problem is primarily attributable to urban development and agricultural activity within the lake's watershed. Numerous dairy and poultry operations within the watershed may also contribute nutrient and bacterial pollution to the lake system. High nutrient loads entering Lake Murray through the Bush River are attributable to upstream wastewater treatment plants (Kimsey et al. 1982). The South Carolina Clean Lakes Survey classified Lake Murray as eutrophic. The lake was phosphorus limited in its forebay (near the dam) but varied seasonally between phosphorus and nitrogen limited conditions in the shallower cove areas.

Robinson Impoundment is a cooling-water reservoir located in the Atlantic Coastal Plain Land Resources Area. The reservoir, constructed in 1959, supplies cooling water for Carolina Power and Light Company's H. B. Robinson Steam Electric Plant. This facility consists of a coal-fired unit which was placed into service in 1960 and a nuclear-powered plant which became operational in 1971. Under normal operating conditions, impoundment waters circulate through the plant's cooling system every 16 days. During the wet and dry seasons, average hydraulic residence times are 37 and 131 days, respectively. Much of the impoundment's $448 \mathrm{~km}^{2}$ watershed is located within the Sandhills National Wildlife Refuge and therefore protected from development. The South Carolina Clean Lakes Survey classified Robinson Impoundment as eutrophic. The reservoir was determined to be phosphorus limited during the summer and fall seasons and nitrogen limited during the winter and spring seasons (Kimsey et al. 1982). The Robinson Impoundment is unique compared to the other reservoirs considered in this study because it is a blackwater system. Its darkly stained waters are extremely soft, low in $\mathrm{pH}$, and possess low nutrient and productivity values (CP\&L 1980).

Richard B. Russell Lake was built in 1984 by the impoundment of the Savannah River at the Russell Dam. Russell Dam is the third multipurpose Army Corps of Engineers project built on the Savannah River and is located at river $\mathrm{km} 442$ between Clarks Hill Dam (river km 379) and Hartwell Dam (river km 490). Richard B. Russell is a multipurpose basin, including power generation, incidental flood control, recreation, streamflow regulation, and water supply. Hydraulic retention time within the reservoir is approximately 102 days. The reservoir inundates all but approximately $1 \mathrm{~km}$ of the Savannah River between Clarks Hill and 
Hartwell Lakes. Russell Lake's drainage area $\left(2.1 \times 10^{3}\right.$ $\mathrm{km}^{2}$ ) is located within the Southern Piedmont Land Resources Area and consists of $60 \%$ woodlands and $40 \%$ pasture/croplands. Only a small portion of the watershed is used for urban and recreational purposes. There are numerous small municipal and industrial wastewater discharges located within the lake's drainage area.

Russell Lake is unique among the chosen reservoirs because the Corps operates a continuous oxygen injection system within the hypolimnion of the lake's forebay. The purpose of this system is to inject pure oxygen into the penstock withdrawal zone to ensure adequate levels of dissolved oxygen (target concentration of $6.0 \mathrm{mg} / \mathrm{L}$ ) in the water discharged to downstream Clarks Hill Lake (COE 1985; COE 1986).

\section{Synoptic Sampling Plan}

When comparing lakes for water quality and community structure, the sampling should be performed as quickly as possible. This "synoptic" type of study is performed in the least amount of time that is logistically feasible. Its objective is to estimate all of the chosen variables within a predetermined timespan (Hutchinson 1957; Mortimer 1974). This strategy minimizes spatial and temporal changes that the researcher seeks to keep constant during the study. In this case, our goal was to sample the ten reservoirs within a period representing maximal thermal stratification and typical summer conditions in the southeastern United States. We chose a time frame of 14 days, during the month of September 1988 and 1989, giving the field crews approximately two days to sample each reservoir offsite from SRS and several hours drive from the laboratory in Aiken, SC where sample processing would oocur each day. Sampling of the three SRS lakes, L Lake, Pond B, and Par Pond required two days for each year's sampling. At each reservoir three types of sampling plans were performed to answer specific questions about the basins' characteristics which are described below.

\section{Longitudinal Basin Gradients}

Transect sampling at a one meter depth was performed to detect and quantify longitudinal gradients in each of the 10 reservoirs with respect to the readily estimated water quality parameters, temperature, $\mathrm{pH}$, dissolved oxygen (DO), conductivity, and chlorophyll $a$. Thornton et al. (1981) has defined three often observed longitudinal zones in a reservoir: riverine, transitional, and lacustrine. The riverine zone is a region of low primary productivity, high nitrogen $(\mathrm{N})$ and phosphorus (P) concentrations, and high light extinction coefficients. High sediment deposition and maximum algal produc- tivity rates characterize the transitional zone. Reduced primary production, $\mathbf{N}$ and $\mathrm{P}$ concentrations, and suspended solids describe the lacustrine region. Semicontinuous samples were collected at closely spaced intervals along a transect (Figure 1, Appendix). This transect was divided into approximately 50 equally spaced intervals with the exception of Pond B, SRP which, due to its smaller size, was partitioned into 25 segments. Beginning at station \#1 the sampling boat continued to next station at a slow fixed speed. At each sampling point the boat glided to a stop. Immediately a submersible electric pump was lowered into the water to a depth of 1 meter and pumping initiated (ca. $60 \mathrm{~L} /$ minute). The water was pumped into a plastic tank, approximately $50 \mathrm{~L}$, for sampling (Figure 2, Appendix). Chlorophyll a was sampled by tapping into the inflowing hose from the submerged pump and passing some of the water through a flow-through cell in a flowmeter to estimate in situ algal fluorescence requiring less than three minutes. After sampling, the boat proceeded to the next sampling station to repeat the same sampling sequence. Figures 5 through 12 in the

Appendix illustrate the sampling stations.

\section{Discrete Offshore Sampling at 1 meter}

Offshore sampling was performed at 1 meter stations $\# 1, \# 2, \# 3, \# 4$, and \#5 in all lakes (to station \#10 in L Lake) consisting of collecting water with a Niskin bottle for total phosphorus, alkalinity, total inorganic nitrogen, turbidity, and dissolved organic carbon (DOC), and estimating Secchi depth (Figure 3, Appendix). The purpose of this sampling plan was to estimate indicators of water quality and trophic conditions along the longitudinal transect line that cannot be easily detected in an automated fashion. Figures 5 through 12 in the Appendix illustrate sampling stations.

\section{Discrete Offshore Sampling Over Depth}

Sampling was performed at 8 discrete depths at stations \#1 and \#5 (station \#10 for L Lake) without replication depended on the vertical distribution of temperature in each lake (Figure 3, Appendix). The chosen depths were 1) just beneath the surface, 2) at one meter, 3) the bottom of the mixed layer or epilimnion, 4) in the middle of the thermocline or equidistant between the bottom of the epilimnion and the top of the hypolimnion, 5) at the bottom of the thermocline or the top of the hypolimnion, 6) one meter below the depth of the fifth sample, 7) a depth equidistant between samples 6 and 8 , and 8) one meter (1) above the sediment-water interface. At each depth a Nisken sample collected water for temperature, $\mathrm{pH}, \mathrm{DO}$, total phosphorus (IP), soluble reactive phosphorus (SRP), total inorganic nitrogen (TIN), nitrate-N, ammonia-N, total inorganic 
carbon (TIC), and total dissolved solids (TSS). Photosynthetically active radiation (PAR 400-700nm) was estimated at every meter from the surface to the $1 \%$ level of incident radiation or 10 meters, whichever was detected first. Figures 5 through 12 in the Appendix illustrate the sampling stations.

\section{Discrete Offshore Sampling Integrated Over Depth}

Samples were collected to assemble phytoplankton and zooplankton taxa lists and estimates of density (individuals per unit volume/area). Samples were collected at stations \#1 and \#5 (station \#10 for L Lake, Figure 3, Appendix). Pooled samples for phytoplankton were collected from the same water bottle samples from the discrete depth sample set above. Enumerations were performed to the species level. Crustacean zooplankton were collected from two triplicate sets of vertical net tows ( $20 \mathrm{~cm}$ diameter bridle opening) performed with both \#10 mesh and \#20 mesh nets (for copepod nauplii only). For each vertical tow the net was lowered to a depth of 30 meters or until the weight attached to the net as ballast hits the bottom. Then the net was pulled to the surface at a speed $\leq 1 \mathrm{~m} / \mathrm{s}$. Copepods were taxonomically segregated to the adult (CVI) instar for both Calanoida and Cyclopoida, total Copepoda copepodites, total Cladocera, and total nauplii. Figures 5 through 12 in the Appendix illustrate sampling stations.

\section{Inshore Benthic Sampling}

Benthic macroinvertebrate samples were gathered to estimate species richness and densities. Sampling (Figure 4, Appendix) was composed of inshore bottom

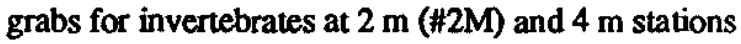
(\#4M). Triplicate PONAR grabs (petite model 0.023 $\mathrm{m}^{2}, 0.6 \mathrm{~mm}$ aperture, US Standard No. 30 ) were collected at each of the inshore stations. Qualitative dip net samples were also collected to supplement the PONAR collections using 3 replicate sweeps with the net for ten (10) man-minutes covering a minimum of $15 \mathrm{~m}$ of shoreline. Figures 5 through 12 in the Appendix illustrate sampling stations.

\section{RESULTS AND DISCUSSION}

\section{Longitudinal Basin Gradients}

Thornton et al. (1981) defined three longitudinal zones in reservoirs, a riverine section where a stream or river enters the upstream portion of the basin, a transitional zone, and a lacustrine region tangent to the reservoir dam. Low primary productivity, high nutrient concentrations, and turbid waters characterize the riverine zone.
High sediment deposition and maximum primary productivity most commonly describe the transitional region, while the lacustrine zone is known for its moderately productive algal community, lower nutrient concentrations, and relatively reduced suspended solid concentrations. Most often these features are observed as significant gradients along the longitudinal axis of a reservoir. These gradients introduce significant horizontal discontinuities into sampling variation that must be quantified for accurate and precise estimates of basinwide features. Our automated transect sampling was designed to detect gradients in the main limnetic region of each reservoir, quantify their features in terms of sampling variation, estimate basin means, and categorize detected gradients in terms of linear or nonlinear spatial trends. With the exception of conductivity, a conservative property regardless of weather influences, the estimated variables could be expected to significantly vary at all time and space scales due to mixing processes (Mortimer 1974).

Immediately apparent (Figures 2 through 6) is the greater between-basin and interannual-basin variation compared to the within-basin variation for all five variables and two sampling years. Temperature ranges of $24^{\circ}$ to $32^{\circ} \mathrm{C}$ at 1 -meter reflected summer surface values normally observed in surface waters of South Carolina (SCWRC 1974). Greater mean temperatures during 1989 were detected in Pond B, Lake Marion, Moultrie, Murray, Robinson, and Russell than in 1988. Thiese differences reflect ephemeral weather pattems immediately prior to that day's sampling.

Values for $\mathrm{pH}$ and dissolved oxygen (DO) are very dependent on photosynthetic rates over diel time scales (Wetzel 1983). Early afternoon results exhibit photosynthetic output that elevates both $\mathrm{pH}$ and $\mathrm{DO}$ and the ambient heterotrophic consumption of oxygen. Note the general similarity of pattern to Figures 3 and 4 . Again station to station variation is relatively small. Lake Robinson and Pond B had pH values significantly lower than the other lakes. These very softwater systems have very low bicarbonate ion concentrations with little buffering capacity.

DO values, as is $\mathrm{pH}$, is dependent on diel photosynthetic rates. There were no large differences between the lakes with values generally indicating a well aerated epilimnion. However, values less than $6 \mathrm{mg} / \mathrm{l}$, as seen in Pond $B$ in 1988 and Lakes Greenwood and Monticello during 1989 reflect probable low photosynthetic rates and heterotrophic oxygen consumption. 
Conductivity, a conservative property indicative of the reservoir's drainage basin and the dissolved salts entering that basin, varied from less than $40 \mathrm{uS} / \mathrm{cm}$ to approximately $130 \mathrm{uS} / \mathrm{cm}$. Three lake groups were apparent in 1988. Low conductivity basins included Pond B, Lake Robinson, and Lake Russell. A second group was comprised of L Lake and Par Pond, supplied with Savannah River water, and Lake Murray. The third group, having higher values, was Lakes Marion, Greenwood, Monticello, and Moultrie. During the 1989 survey a similar pattem was observed with a single exception, Lake Greenwood which had relatively greater values.

Chlorophyll $a$ is a useful indicator of algal biomass and spanned a threefold range for the lakes in 1988 and a fourfold range in 1989. Two groups are seen in Figure 6. Pond B, Par Pond, Lake Monticello, and Lake Murray had concentrations approximately less than 7 $\mathrm{mg} / \mathrm{l}$ which is the lower limit for being classified as an oligotrophic lake (EPA-NES 1974). Only Lake Marion had values exceeding $12 \mathrm{mg} / \mathrm{l}$ which categorizes it as a eutrophic basin. During 1989, Par Pond, Lake Marion, Lake Greenwood, and Lake Moultrie had concentrations greater than $12 \mathrm{mg} /$. L Lake would be classified as mesotrophic with the remaining basins being classified as oligotrophic. Again sampling variation along each transect was minimal.

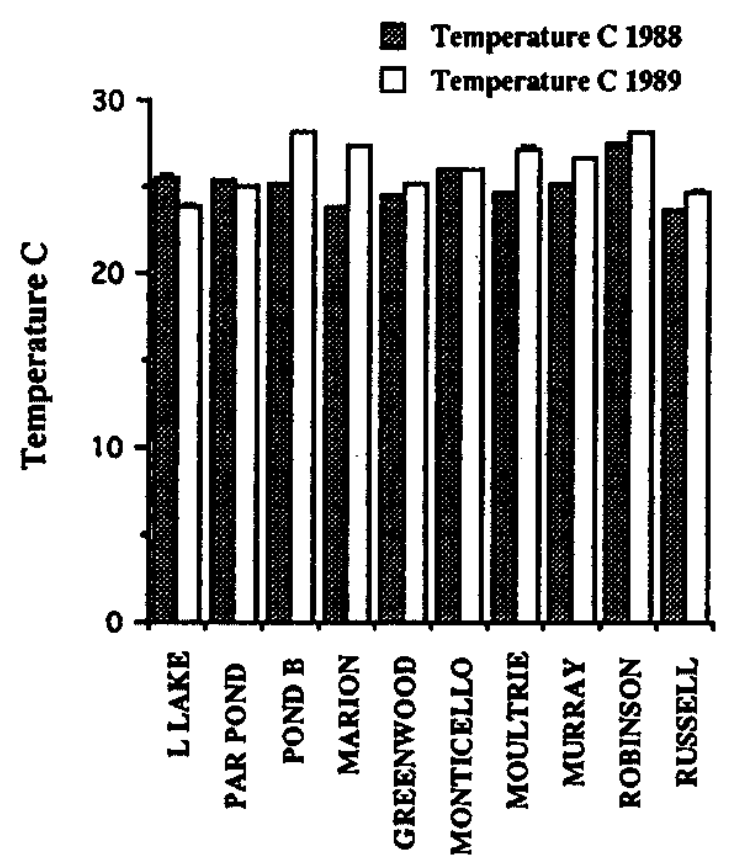

Figure 2. Means and Standard Errors (SEs) of temperature in September 1988 and 1989.

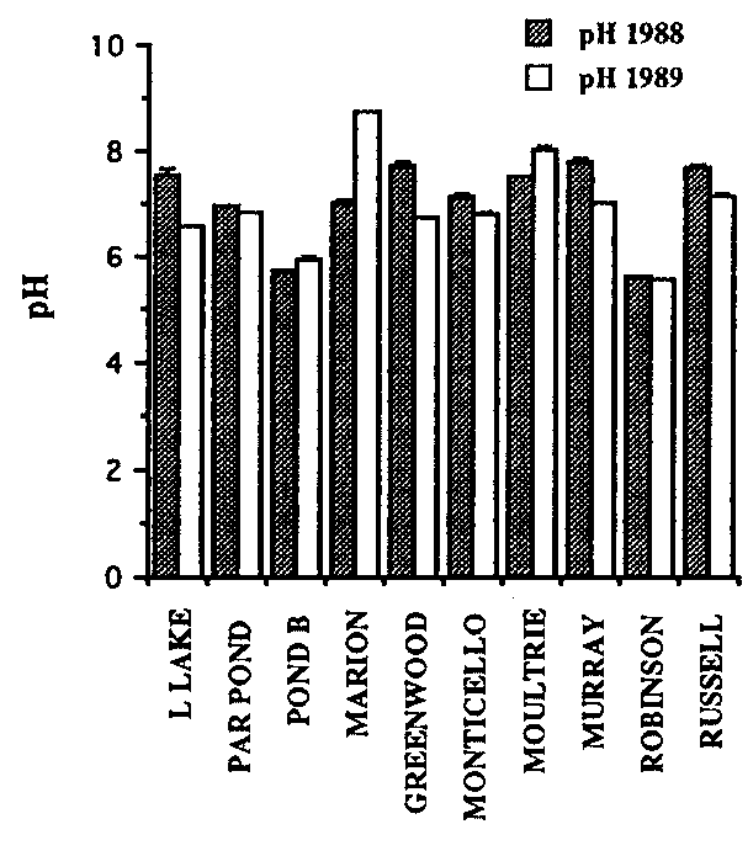

Fig 3. Means and Standard Errors (SEs) of $\mathrm{pH}$ in September 1988 and 1989.

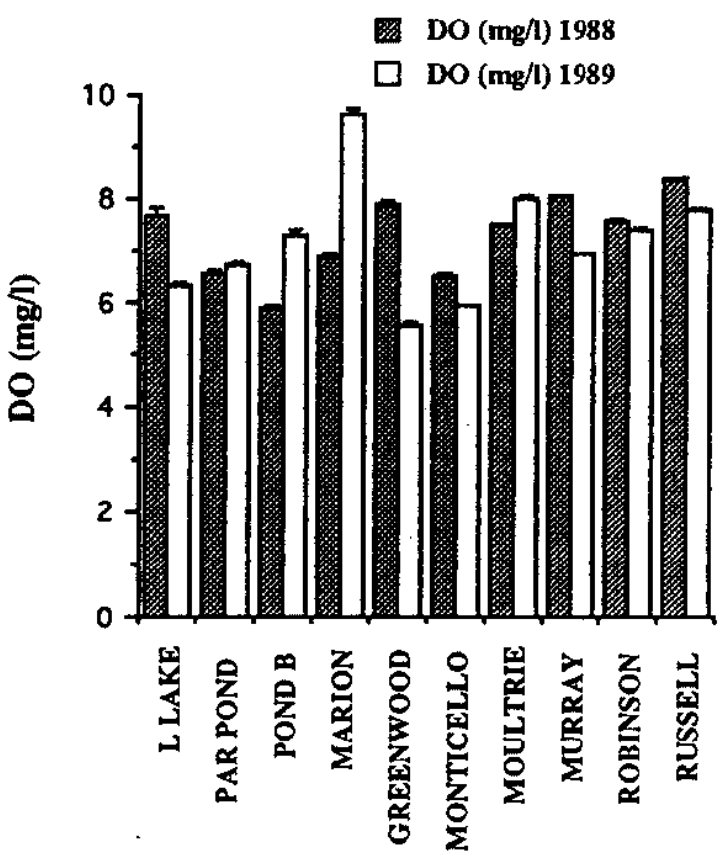

Figure 4. Means and Standard Errors (SEs) of DO in September 1988 and 1989. 


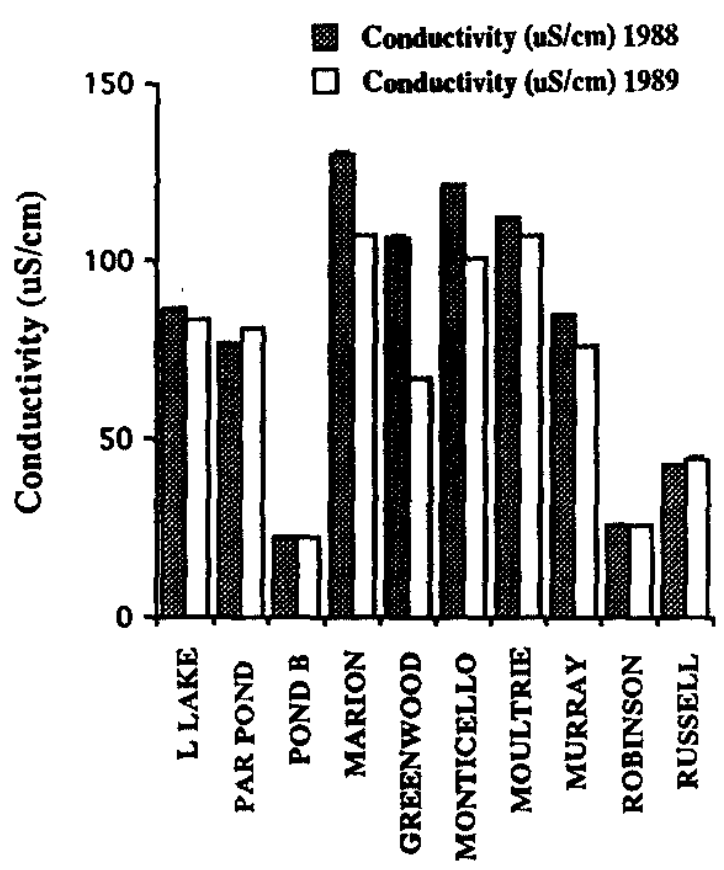

Figure 5. Means and Standard Errors (SEs) of conductivity in September 1988 and 1989.

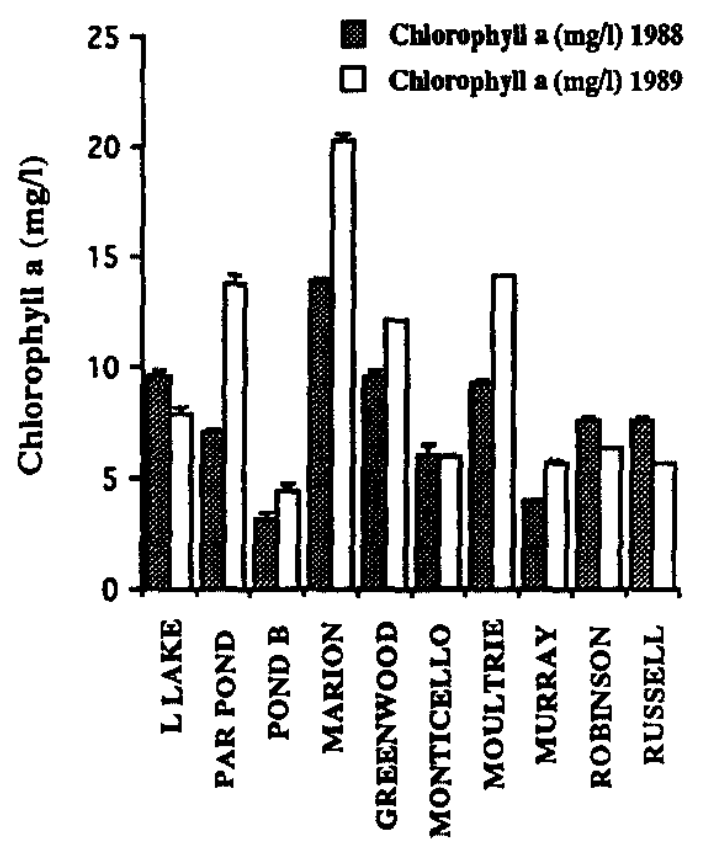

Figure 6. Means and Standard Errors (SEs) of chlorophyll $a$ in September 1988 and 1989.
Although no large scale variation or gradients were observed from the transect sampling, small gradients and patterns of variation were detected. The transect sampling began near the reservoirs' dam or outfall area and proceeded continually upstream. The results indicated horizontal uniformity along the longitudinal axis of each lake. The type of gradient was categorized and quantified by regressing each variable against distance along the transect thus defining the nature of the gradient. Both linear and nonlinear trends or "fits" were statistically significant. Because of the large matrix created by these analyses Figures 7 and 8 collapse the results into a more manageable picture. If linear "fits" were not statistically significant, nonlinear polynomial equations were fitted. Sometimes within these small ranges of variation no polynomial could be fit to the data because of variation.

There were no consistent or obvious interannual trends and only some significant correlations between water quality parameters within any particular lake. The driving forces behind these correlations are photosynthesis that requires a hydrogen donor and nutrients. Significant algal biomass and production, which is often proportional to temperature, removes hydrogen ions from the water column. In poorly buffered waters with a paucity of bicarbonate ion $\mathrm{pH}$ values increase significantly during an afternoon's primary production along with concurrent increases in DO. Therefore, the large number of significant positive correlations between $\mathrm{pH}$ and DO are not surprising. The lack of significant correlations in these results stems from secondary effects of nutrient limitation, heterotrophic oxygen consumption, zooplankton grazing, and sampling variation.

These observations have been extensively documented for all types of ponds, natural lakes, impoundments, and open oceanic waters (see Steele 1989 for review). Weather conditions profoundly affect the detected gradients. Wind mixing within 24 hours of the sampling period will largely determine the nature of these stochastically determined gradients (Mortimer 1974). 


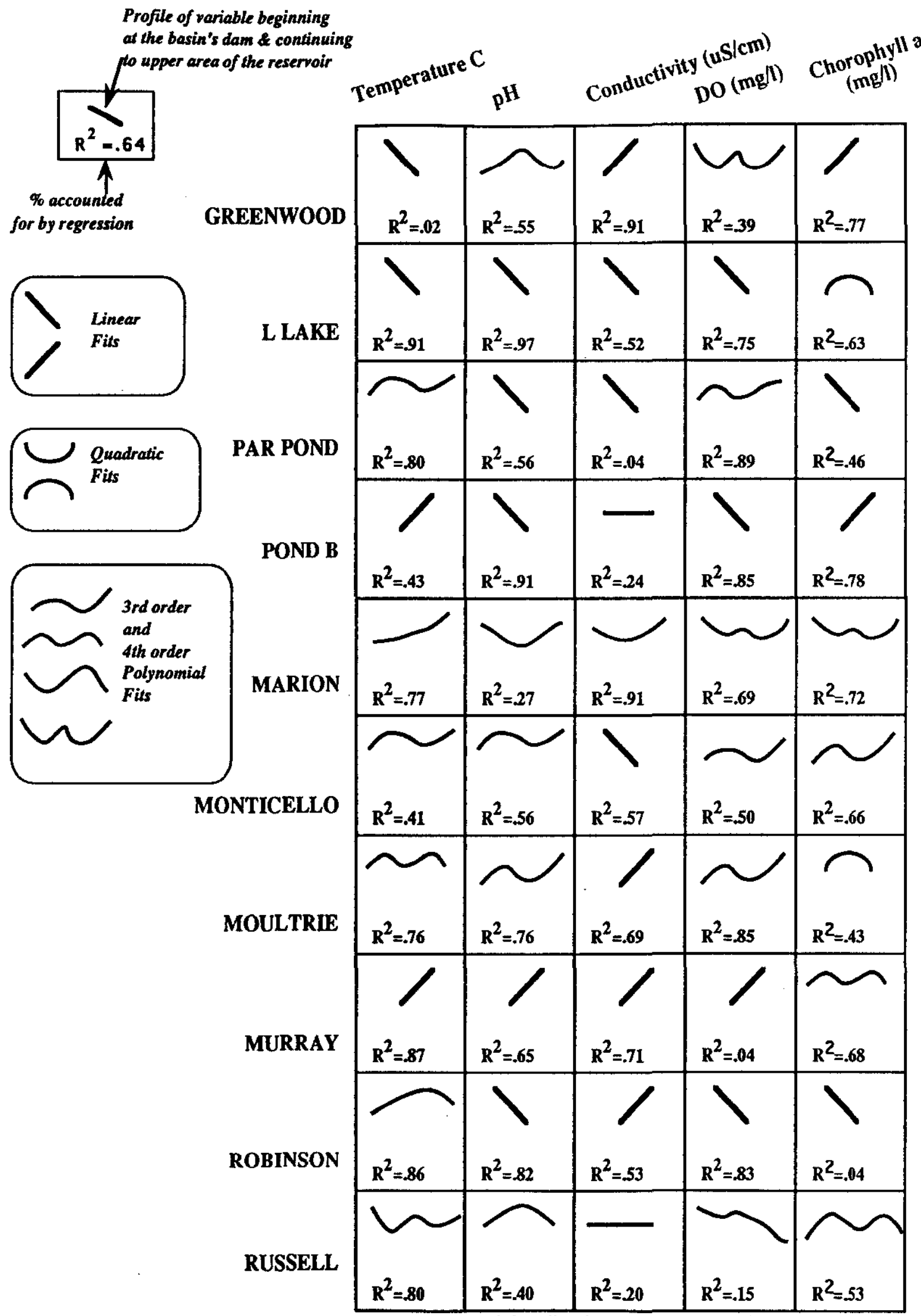

Figure 7. Regression analyses of temperature, $\mathrm{pH}$, conductivity, dissolved oxygen, and chlorophyll a results from transect sampling during 1988. 


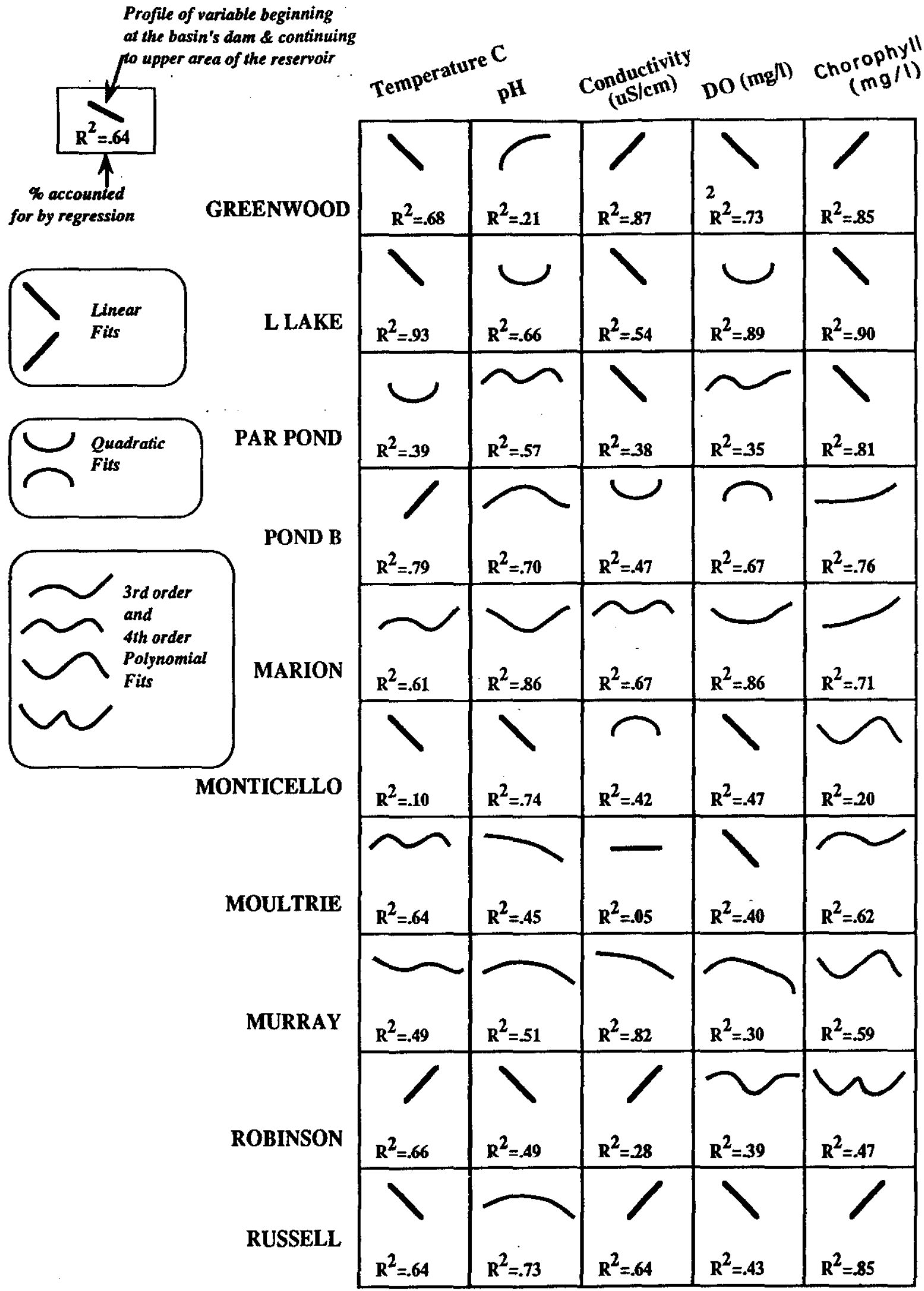

Figure 8. Regression analyses of temperature, $\mathrm{pH}$, conductivity, dissolved oxygen, and chlorophyll a results from transect sampling during 1989. 
Discrete Offshore Sampling at 1 meter

In addition to the 50-station transect sampling at 1 meter, discrete samples were also collected at 1 meter for alkalinity, Secchi depth, total phosphorus (TP), dissolved organic carbon (DOC), turbidity, nitrite/nitrate nitrogen $(\mathrm{N})$, and ammonia $\left(\mathrm{NH}^{4}\right)$ at five stations along the transect sampling line. The purpose of these measurements was to estimate these commonly used indicators of water quality which cannot easily be part of an automated sampling program.

Secchi depth estimates in 1988 indicated that Pond B and Lake Murray possess the clearest water columns with depths near 3 meters (Figure 9). Lakes Marion, Greenwood, and L Lake had the shallowest depths primarily due to algal densities and inorganic suspended matter. During 1989 Pond B and Lake Murray had again the clearest water columns. Other differences were minor and could easily represent the natural variation due to mixing episodes immediately prior to sampling.

Alkalinity (Figure 10) was relatively low in all reservoirs when compared to most lakes in North America (Hutchinson 1967). All of the mean values for both 1988 and 1989 were less than $30 \mathrm{mg} / \mathrm{which}$ is substantially lower from hardwater lakes having values typically exceeding $100 \mathrm{mg} /$. Lake Robinson and Pond B are very softwater basins with little buffering capacity.

Total phosphorus (TP), perhaps the most widely used indicator of trophic status in lakes, is one of the best single indicators of potential primary production in community because it is that algal growth element least abundant in freshwater (Rigler 1964, 1966, 1968, 1973). During $1988 \mathrm{~L}$ Lake and Lake Marion had the highest concentrations (Figures 11). Pond B, Lake Murray, Lake Robinson, and Lake Russell had the lowest concentrations which still was approximately $10 \mathrm{ug} /$. These magnitudes were significantly greater than most oligotrophic systems. Concentrations during 1989 did not alter this general pattern.

Nitrogen most often limits algal growth in freshwater systems when phosphorus concentrations are at saturation for algae in eutrophic basins. Ammonia is the preferred form nitrogen followed by nitrate and nitrite. During the 1988 and 1989 L Lake, Lake Greenwood, and Lake Monticello survey had significantly higher concentrations of nitrite/nitrate compared to the other lakes (Figure 12). Ammonia, the preferred pathway of uptake by phytoplankton, was again greatest in L Lake and Lake Monticello.
DOC, which includes a significant colloidal fraction, represents most of the carbon in lakewater with the exception of dissolved inorganic carbon (Wetzel and Rich 1973). Resistant to microbial degredation, its sources and chemical composition are largely unknown. However, DOC estimates are a reasonable measure of nonliving organic matter in aquatic environments. Concentrations during the 1988 and 1989 surveys ranged from approximately 3 to $11 \mathrm{mg} /$. Lake Marion, Par Pond, and Lake Moultrie had the lowest concentrations while L Lake and Lake Greenwood had the greater concentrations (Figure 14).

Turbidity, another more quantitalive measure of water clarity and indirect indicator of suspended solids, was highest in Lakes Marion, Greenwood, and Monticello with Pond $B$ and Lake Murray being the least turbid (Figure 15). The pattern was repeated in 1989.

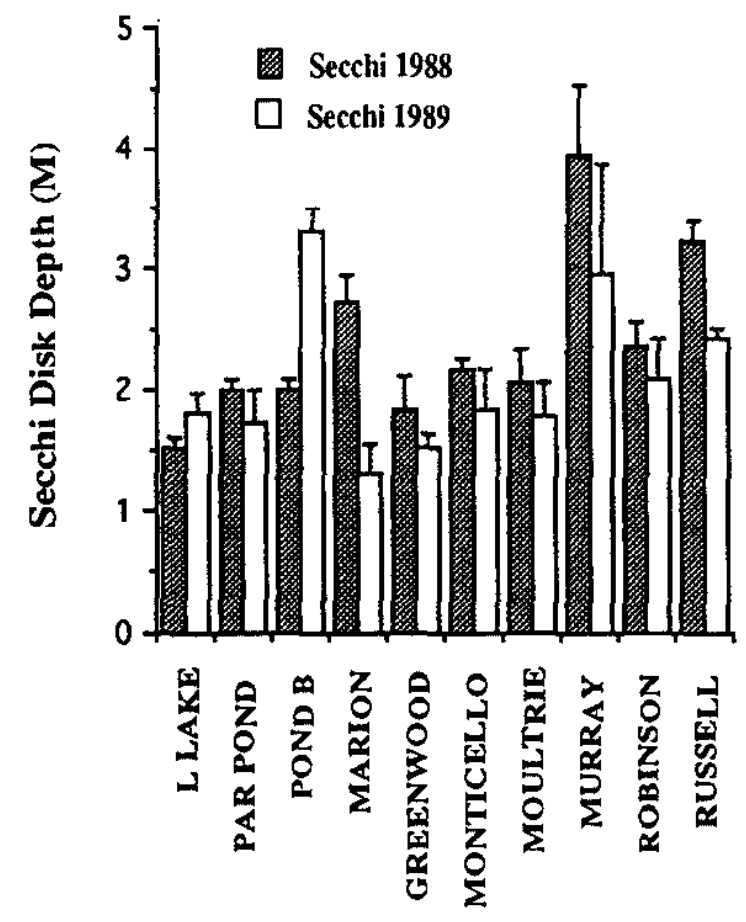

Figure 9. Mean and $\mathrm{SE}$ for Secchi depth at 1-meter from 5 stations along the transect in each lake in 1988 and 1989. 


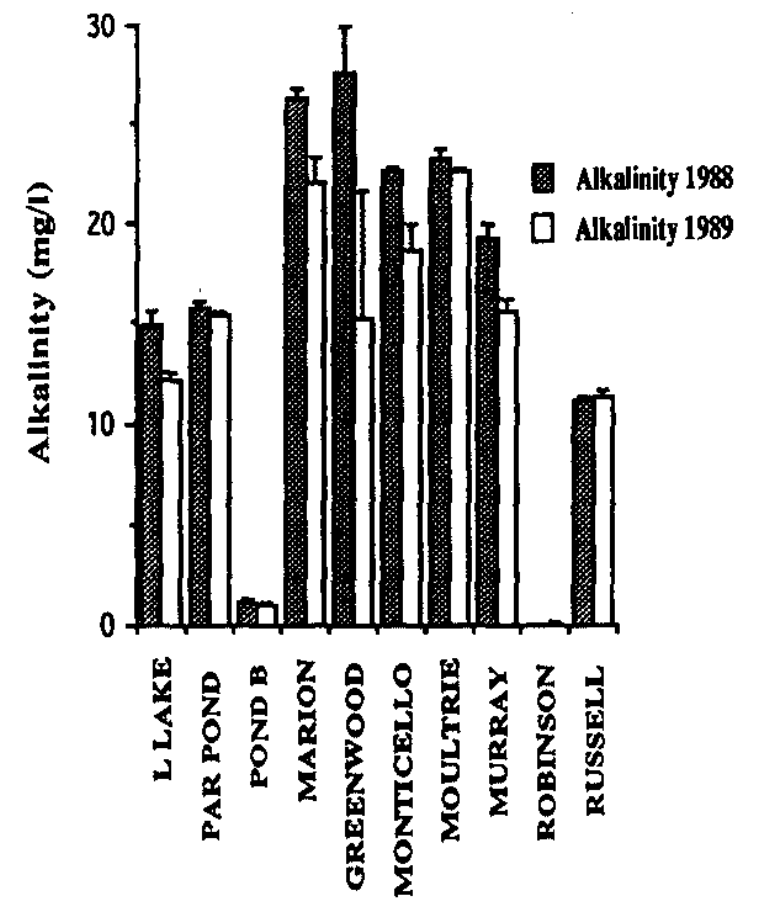

Figure 10. Mean and SE for alkalinity at 1-meter from 5 stations along the transect in each lake in 1988 and 1989.

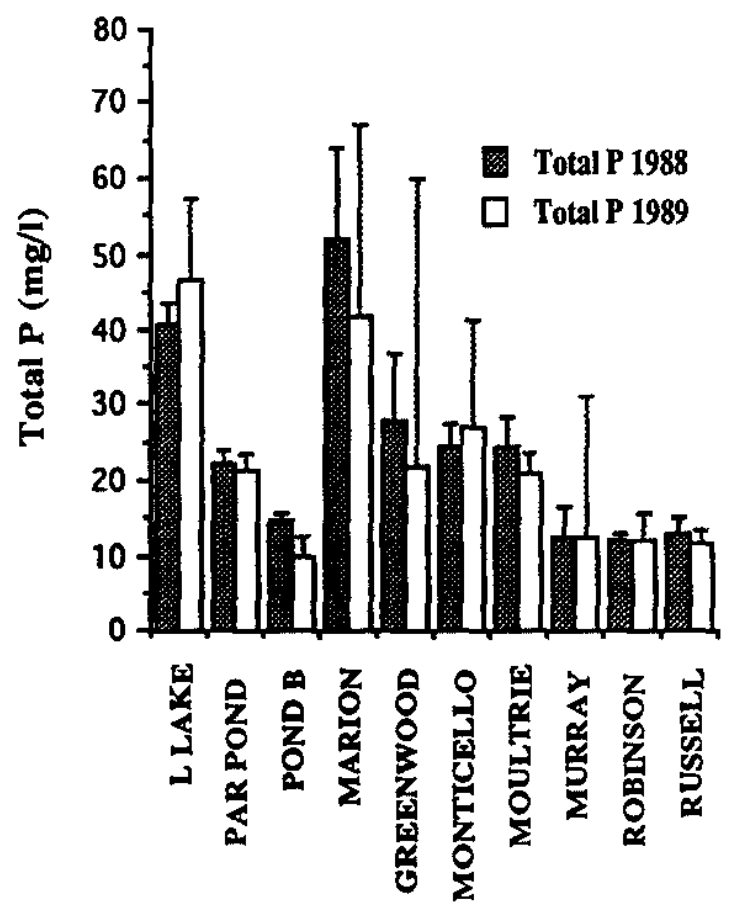

Figure 11. Mean and SE for total phosphorus (TP) at 1meter from 5 stations along the transect in each lake in 1988 and 1989.

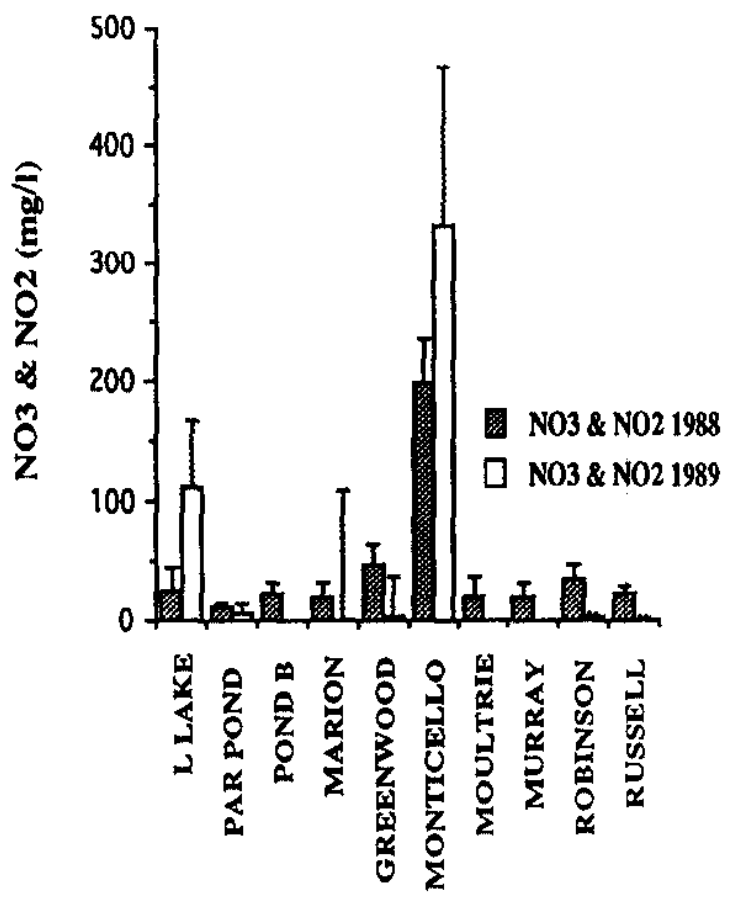

Figure 12. Mean and SE for nitrate and nitrite at 1-meter from 5 stations along the transect in each lake in 1988 and 1989.

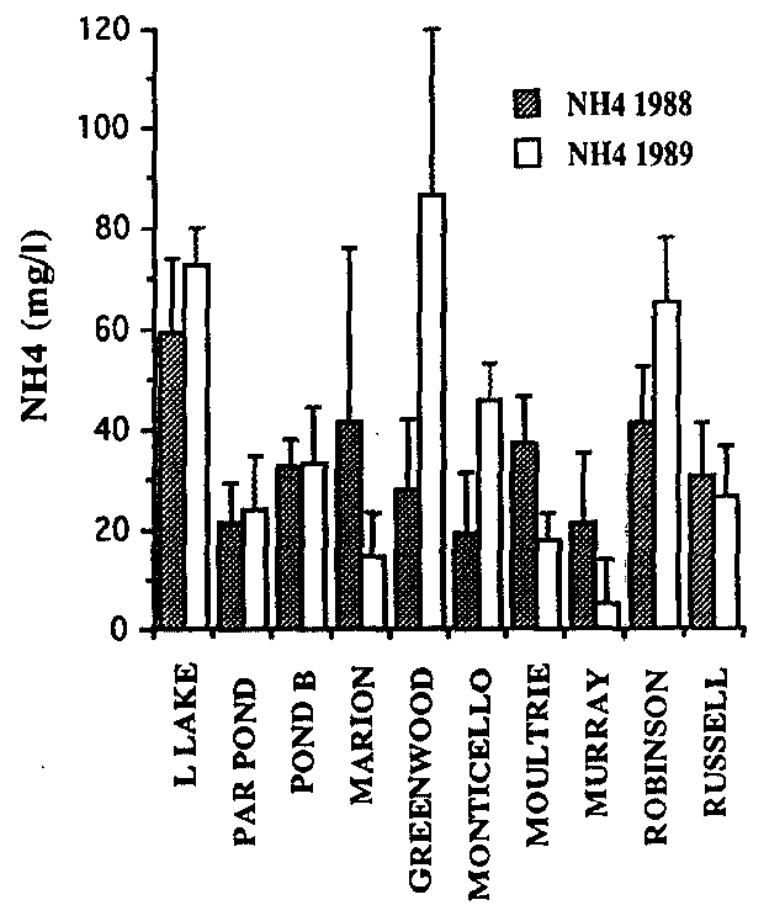

Figure 13. Mean and SE for ammonia at 1-meter from 5 stations along the transect in each lake in 1988 and 1989. 


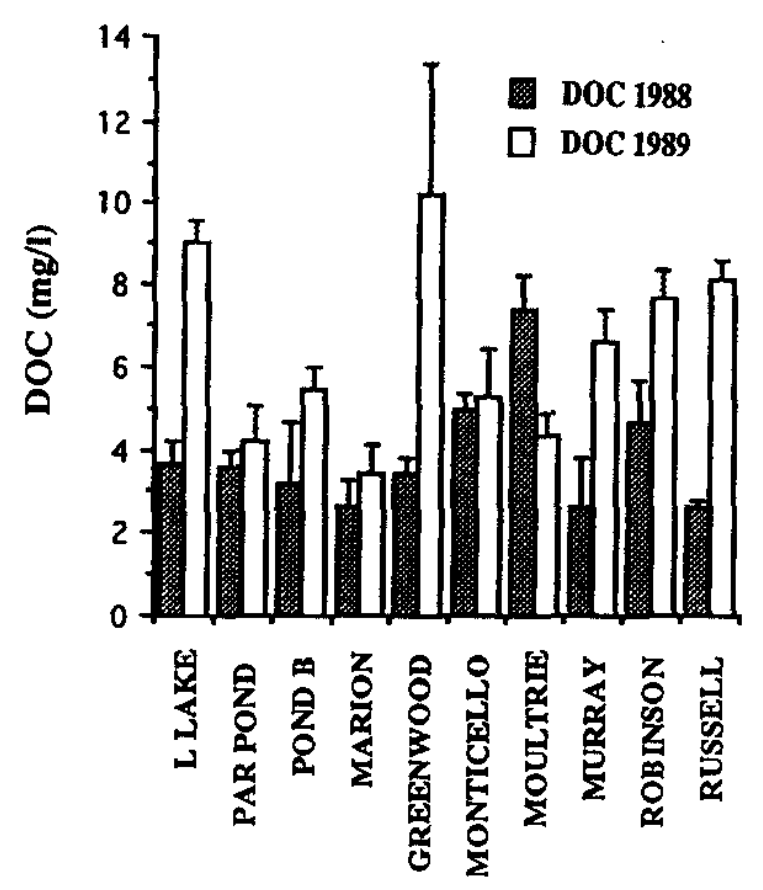

Figure 14. Mean and SE for dissolved organic carbon (DOC) at 1-meter from 5 stations along the transect in each lake in 1988 and 1989.

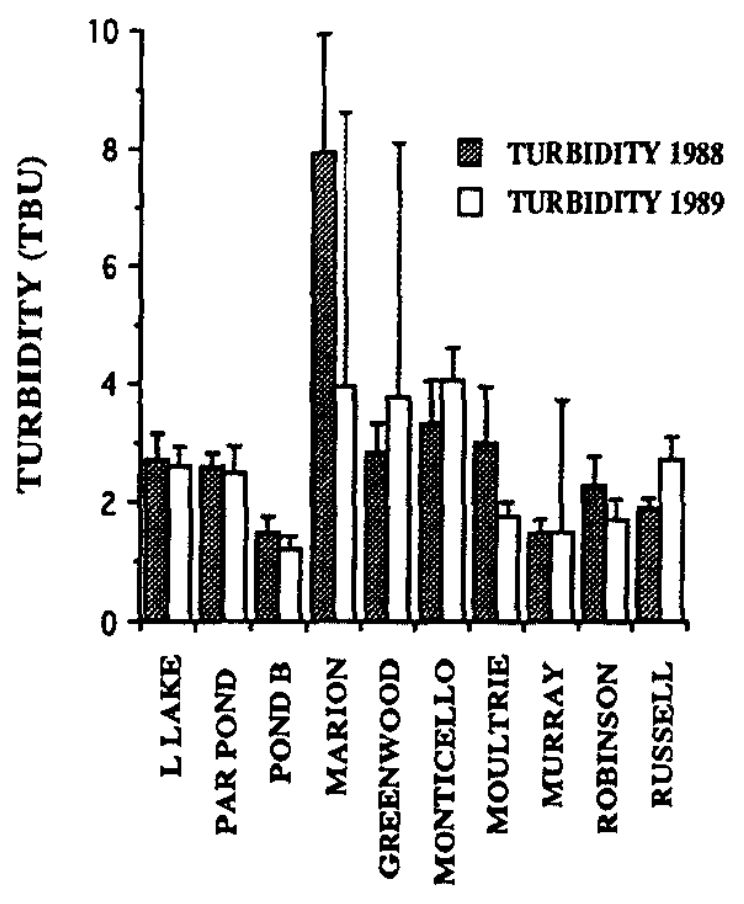

Figure 15. Mean and SE for turbidity at 1-meter from 5 stations along the transect in each lake in 1988 and 1989.
Multivariate Analyses of Transect and 1-Meter Discrete Sampling

The magnitudes and variations associated with the above water quality variables naturally suggest attempts to group the ten reservoirs in some objective quantitative fashion. Cluster analysis is one exploratory technique, which seeks to classify treatment variables, in this case the ten lakes, into meaningful categories for further study (Wetzel 1975). This method was performed for all of the above variables (Figures 16 and 17). In the 1988 and 1989 analyses Pond B, Lake Russell, and Lake Robinson cluster together first due mainly to low alkalinity and $\mathrm{pH}$, all very poorly buffered systems. Relative to the other basins these reservoirs also possess low nitrogen levels. Par Pond and Lake Murray consistently grouped together with lesser affinities with Lakes Moultrie, Greenwood, and Marion. L Lake and Lake Monticello consistently grouped together due to their high nitrogen concentrations. Note also that these basins were separated out last and showed the least affinities for the other eight basins. Three main groupings resulted, L Lake and Lake Monticello, due to their high levels of nitrogen, Lakes and Robinson and Russell, and Pond B, for their low pH, alkalinities, and nitrogen concentrations, and the remaining Lakes Marion, Moultrie, Greenwood, Par Pond, and Murray loosely associated for their near median characteristics.

\section{Indicators of Eutrophication}

The United States Environmental Protection Agency (USEPA, EPA-NES 1974) has used three major indicators of trophic status based on chlorophyll a, Secchi disk depth, and TP. Local, county, state, and federal government agencies have then ranked lacustrine surface waters with these easily used techniques. Figures 18 and 19 illustrate those rankings for the studied basins during the 1988 and 1989 surveys. In 1988 Lake Marion, L Lake, and Lake Greenwood were consistently ranked highest in trophic status at the meso/eutrophic classification. Only Lake Murray was always classified as oligotrophic reservoir. Pond B shared this distinction in 1989 with Lake Murray immediately following in rank. Successional effects are seen with the L-Lake results with regards to water clarity and algal biomass.

Because of the uniqueness of these synoptic surveys, two classic relationships invite assessment. Intuitively as phytoplankton densities decrease, chlorophyll $a$ concentrations will concurrently decline resulting in an increased Secchi depth. Figure 20 illustrates this inverse relationship. Linear correlations collaborate both figures $(1988, r=-0.91 / P \leq 0.01 ; 1989, r=-0.77 / P \leq 0.01)$.

The second relationship plots the $\log 10$ of chlorophyll $a$ versus the $\log _{10}$ of TP. 
This linear proportionality (Figure 21), more than any other, has provided the founding principles of nutrient limitation (Droop 1973, 1974; Dugdale 1976; Schindler 1977).

Distance metric is Euclidean Distance

Single linkage method (Nearest Neighbor)

0.000

Distances

20.00

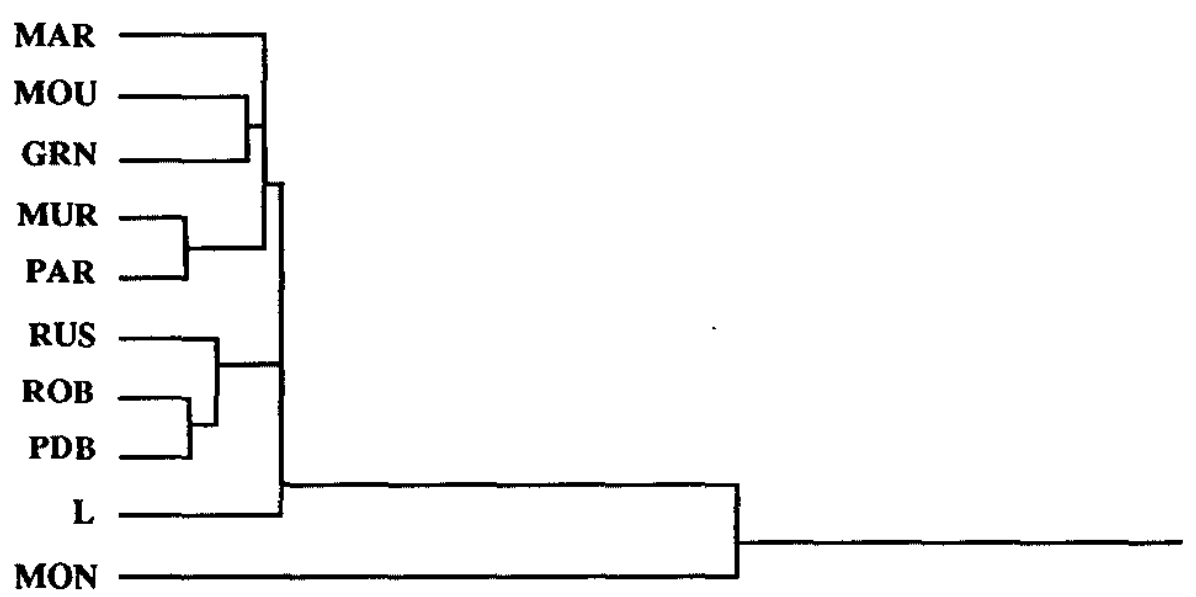

Figure 16. Dendrogram from Euclidean distance cluster analysis of lakes by conductivity, $\mathrm{pH}$, alkalinity, dissolved organic carbon, total phosphorus, nitrate, nitrite, and ammonia in 1988.

Distance metric is Euclidean Distance

Single linkage method (Nearest Neighbor)

$\begin{array}{ll}0.000 & \text { Distances }\end{array}$

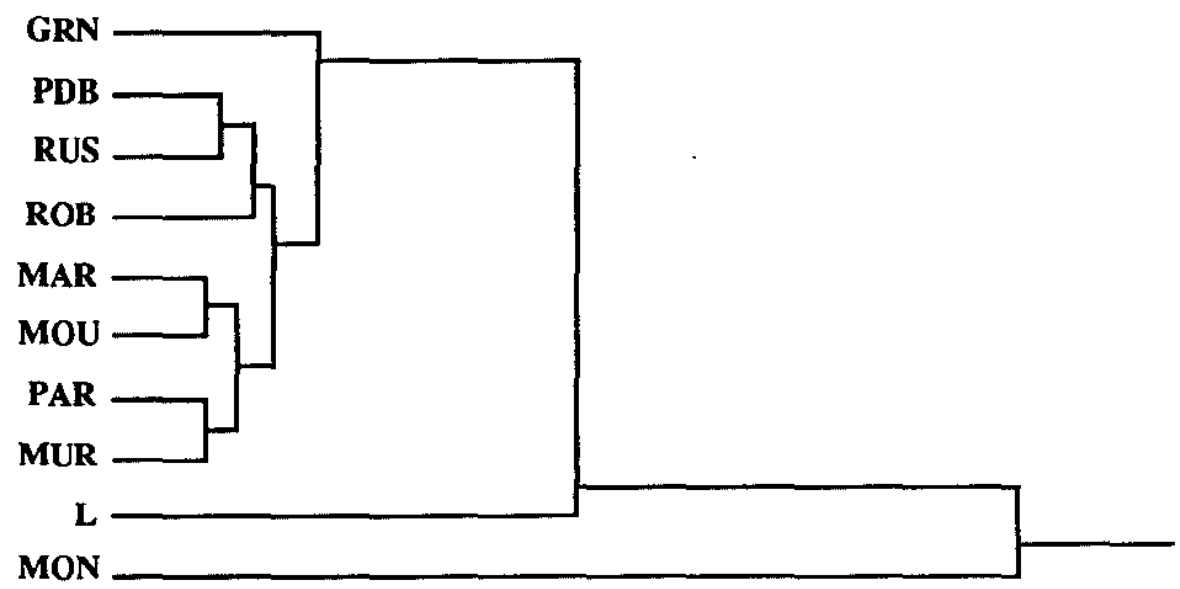

Figure 17. Dendrogram from Euclidean distance cluster analysis of lakes by conductivity, $\mathrm{pH}$, alkalinity, dissolved organic carbon, total phosphorus, nitrate, nitrite, and ammonia in 1989. 

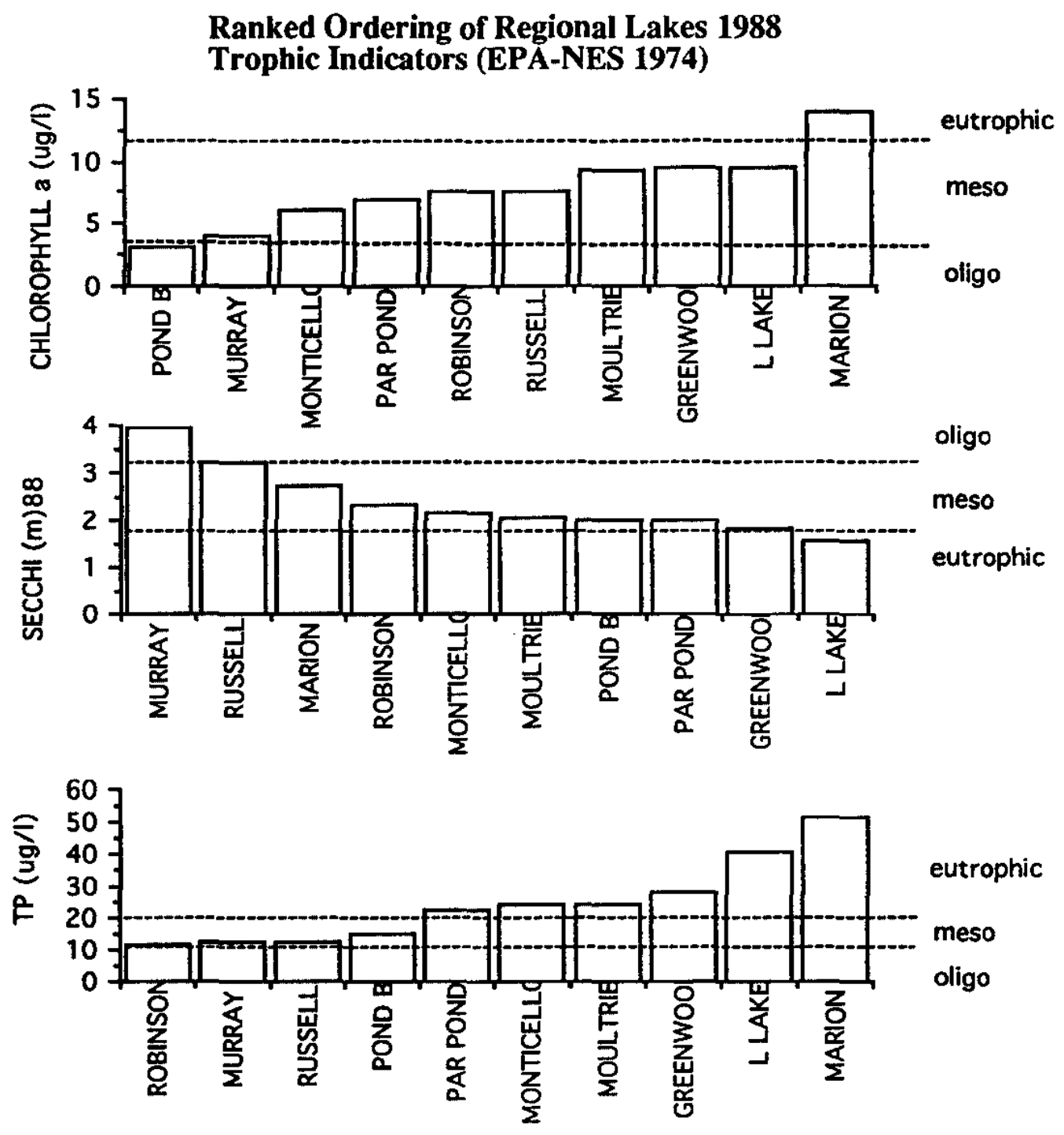

Figure 18. Ranking of the ten South Carolina reservoirs according to three EPA trophic indicators during 1988. 
Ranked Ordering of Regional Lakes 1989

Trophic Indicators (EPA-NES 1974)
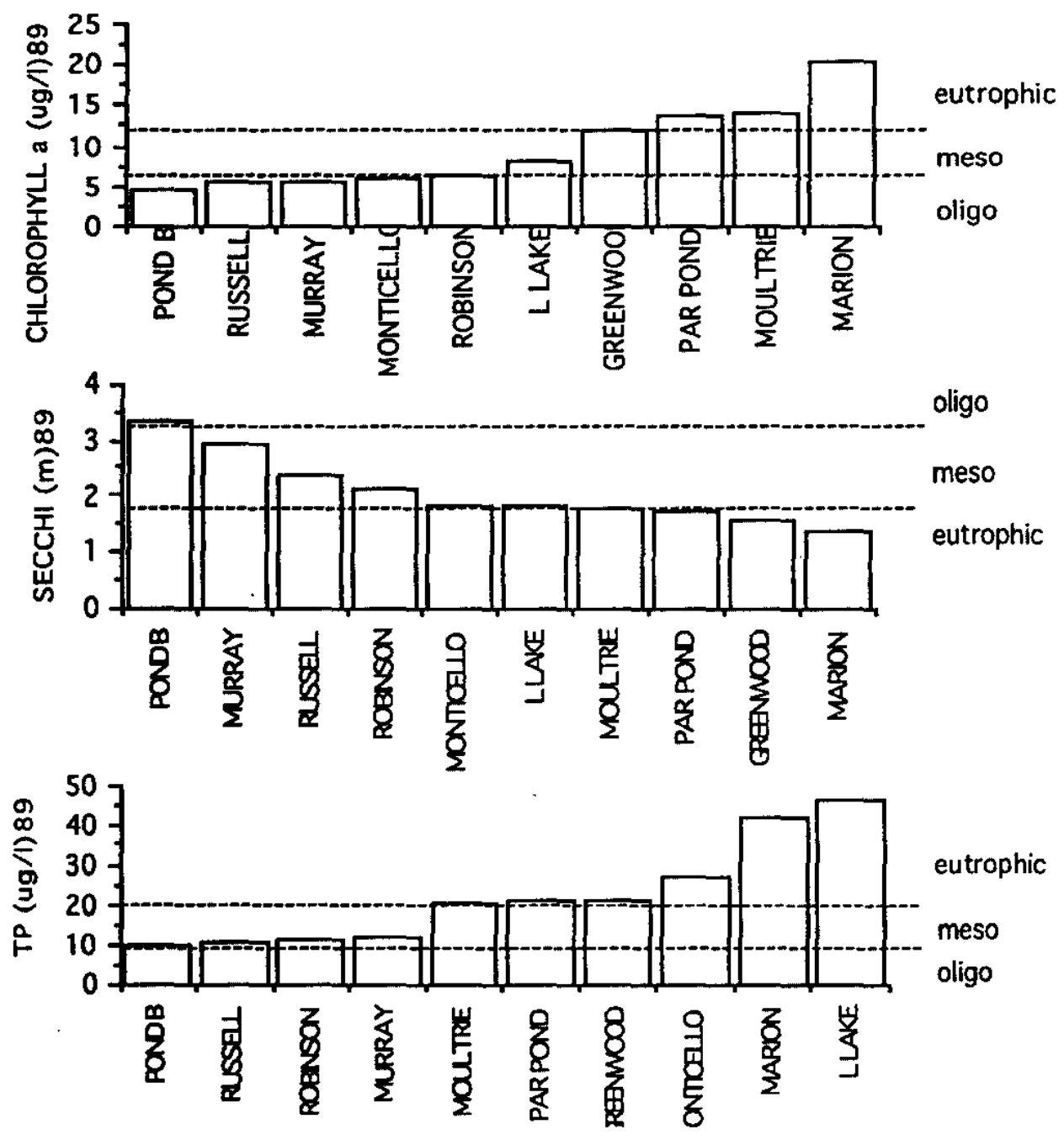

Figure 19. Ranking of the ten South Carolina reservoirs according to three EPA trophic indicators during 1989. 


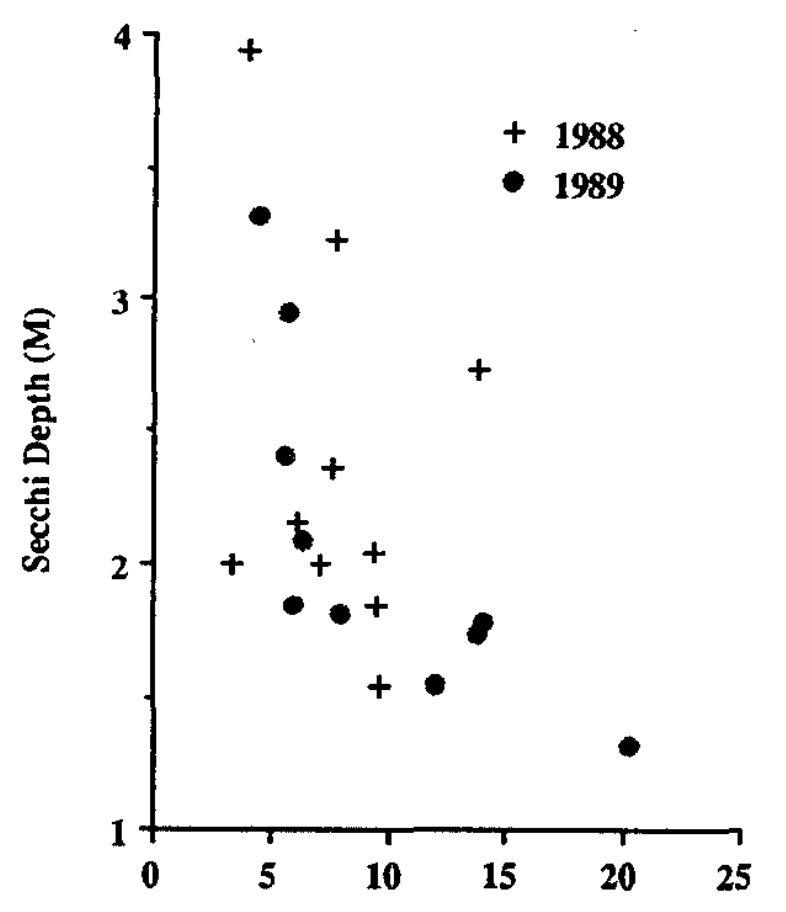

Chlorophyll a (mg/l) 1988

Figure 20. Relationship between Secchi disk depth and chlorophyll $a$ in the ten South Carolina reservoirs during 1988.

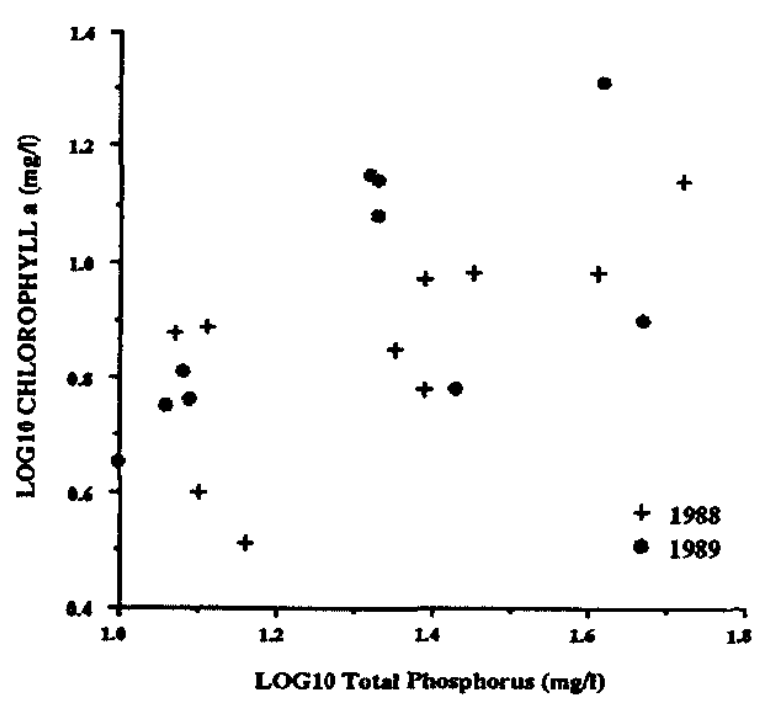

Figure 21. Relationship between $\log 10$ of chlorophyll a versus the $\log _{10}$ of TP in the ten South Carolina reservoirs during 1988.
Vertical Structure during Thermally Stratified Conditions

Hutchinson (1957,1976) and Wetzel (1975) have extensively discussed the vertical distribution of water quality variables during thermally stratified conditions. These distributions are good indicators of trophic conditions in lakes and reservoirs. Hutchinson (1957) stated that if only two variables could be measured, it would be the vertical distribution of temperature and DO during midsummer. More than any other combination of variables these two indicate the viable habitat for aquatic life. Figures 22 through 25 illustrate in each case oxygen depletion in the hypolimnion resulting in two major consequences, inhabitability for most animals and the release of dissolved phosphorus from the lakes' sediments which is then available for algal consumption. None of the basins possessed an orthograde oxygen curve, indicative of oligotrophic conditions.

The penetration of photosynthetically active radiation (PAR) and the approximate depth of the $1 \%$ incidence light level, the "compensation depth" (Wetzel 1975) are good indicators of the maximum depth of net primary production. In 1988 and $1989 \%$ PAR profiles indicated that strata below 10 meters cannot support significant photosynthetic activity (Figures 26 and 27). The third sampling depth in each figure was collected at the bottom of the epilimnion or mixed layer. Note that in all basins no significant light penetrates into the thermocline, so common in more pristine basins.

The effects of an anoxic hypolimnion and the release of dissolved orthophosphorus were observed in most lakes with the exceptions of Lake Marion, Lake Moultrie in 1988 and 1989 with the addition of Lake Robinson and Pond B in 1989 (Figures 28 through 31). These increasing concentrations of available phosphorus are brought to the surface by localized upwelling events or Poincare' waves further stimulating algal production (Dugdale 1967). In summary these vertical distributions indicate the general character of mesotrophic and eutrophic conditions in South Carolina reservoirs. 


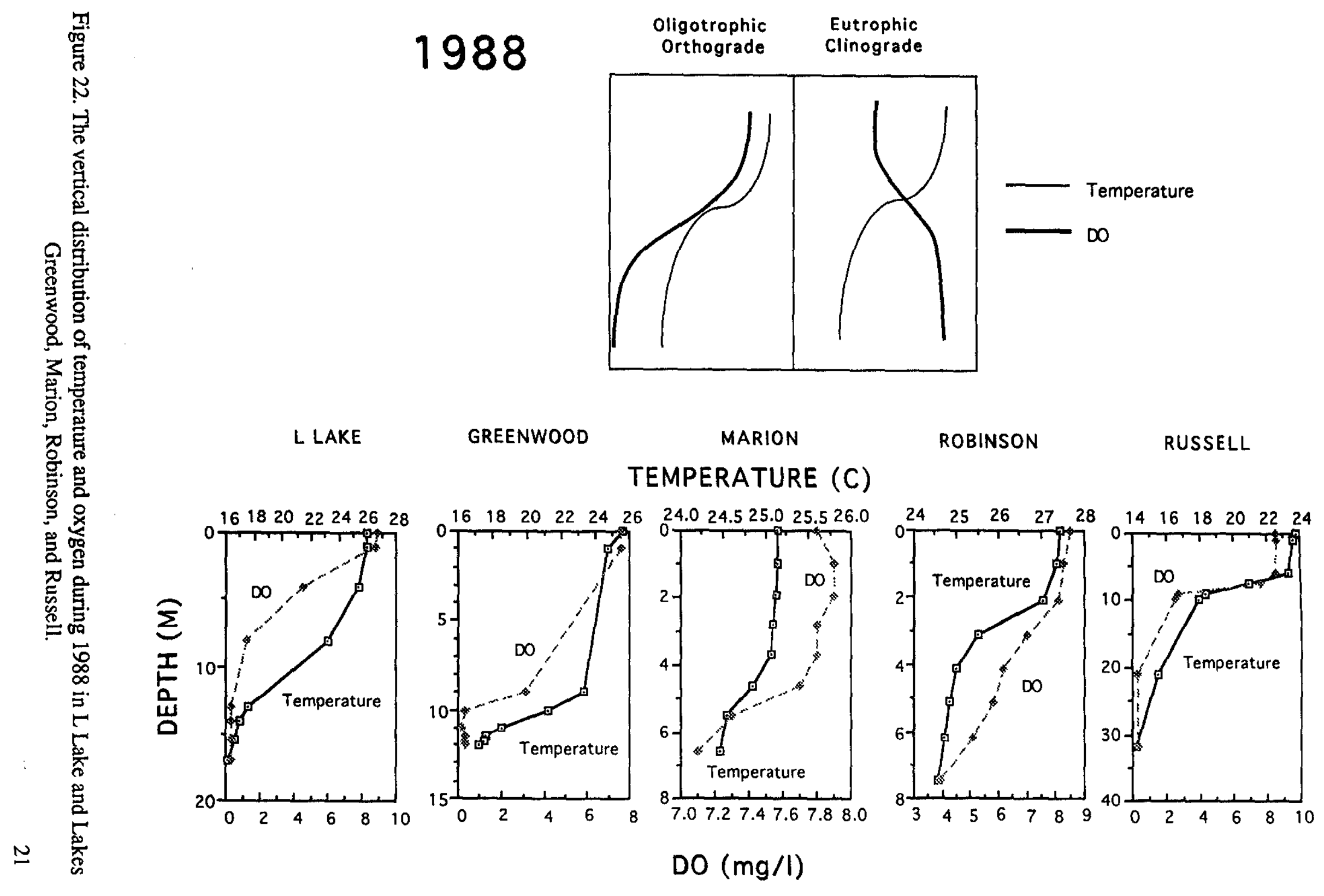


$\tilde{\perp}$

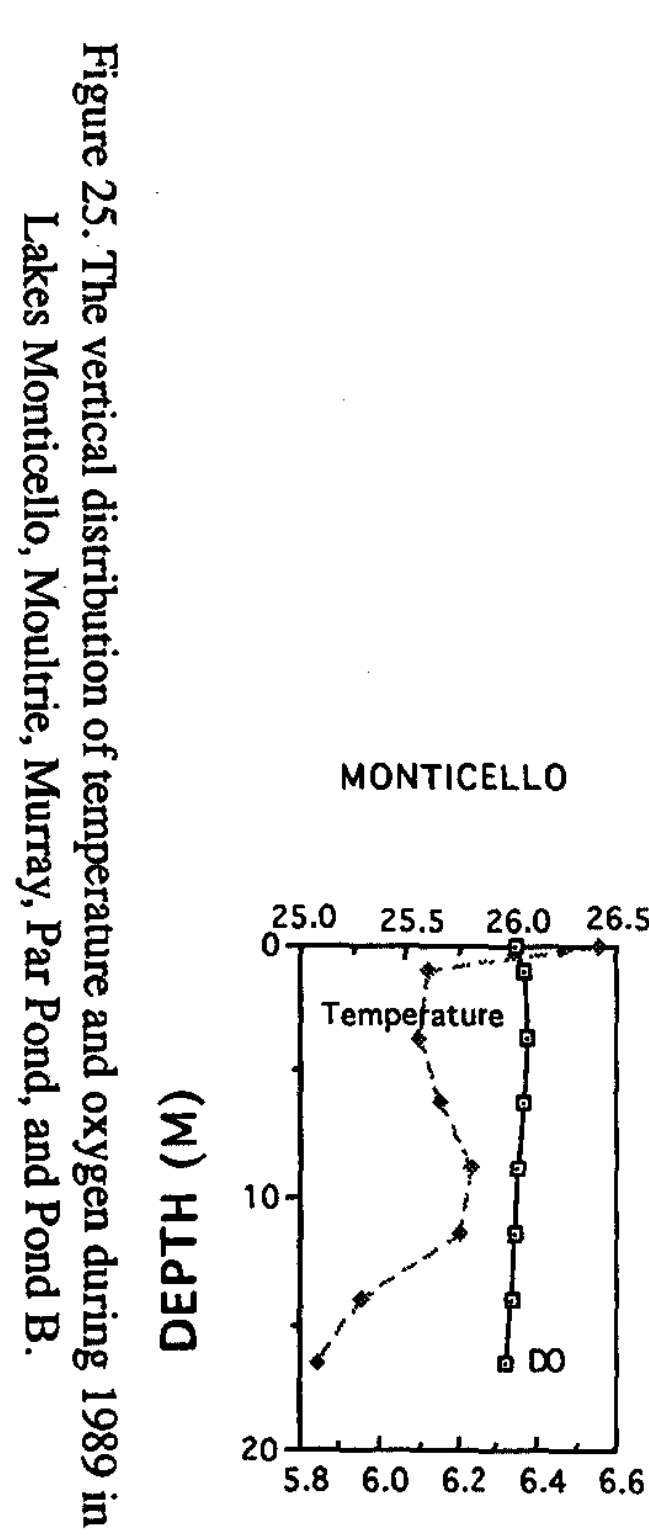

1989

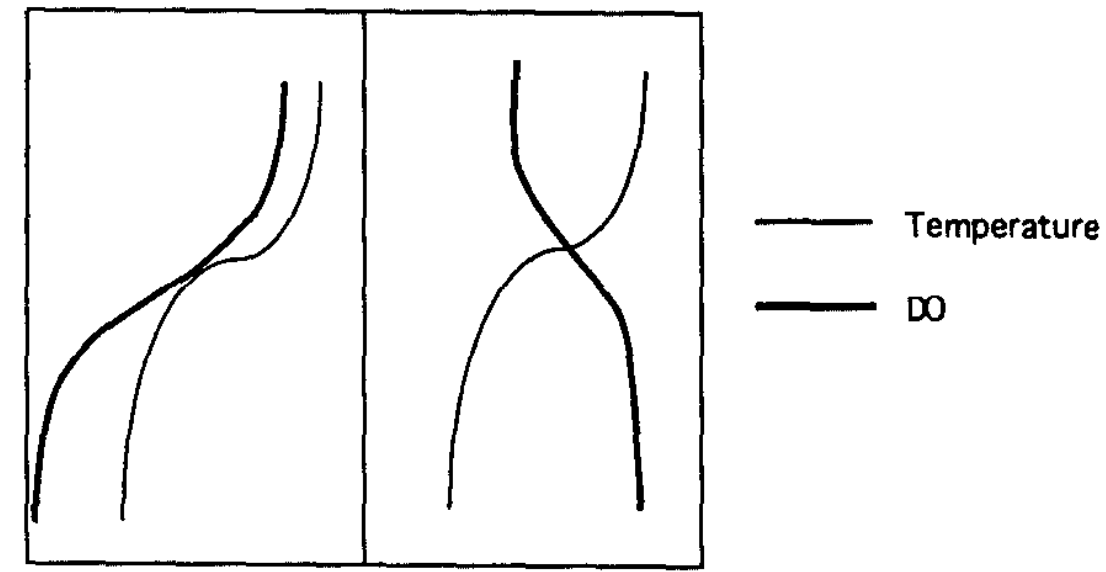

MOULTRIE Orthograde

POND B

PAR POND
Oligotrophic
Eutróphic

Clinograde

\section{TEMPERATURE (C)}
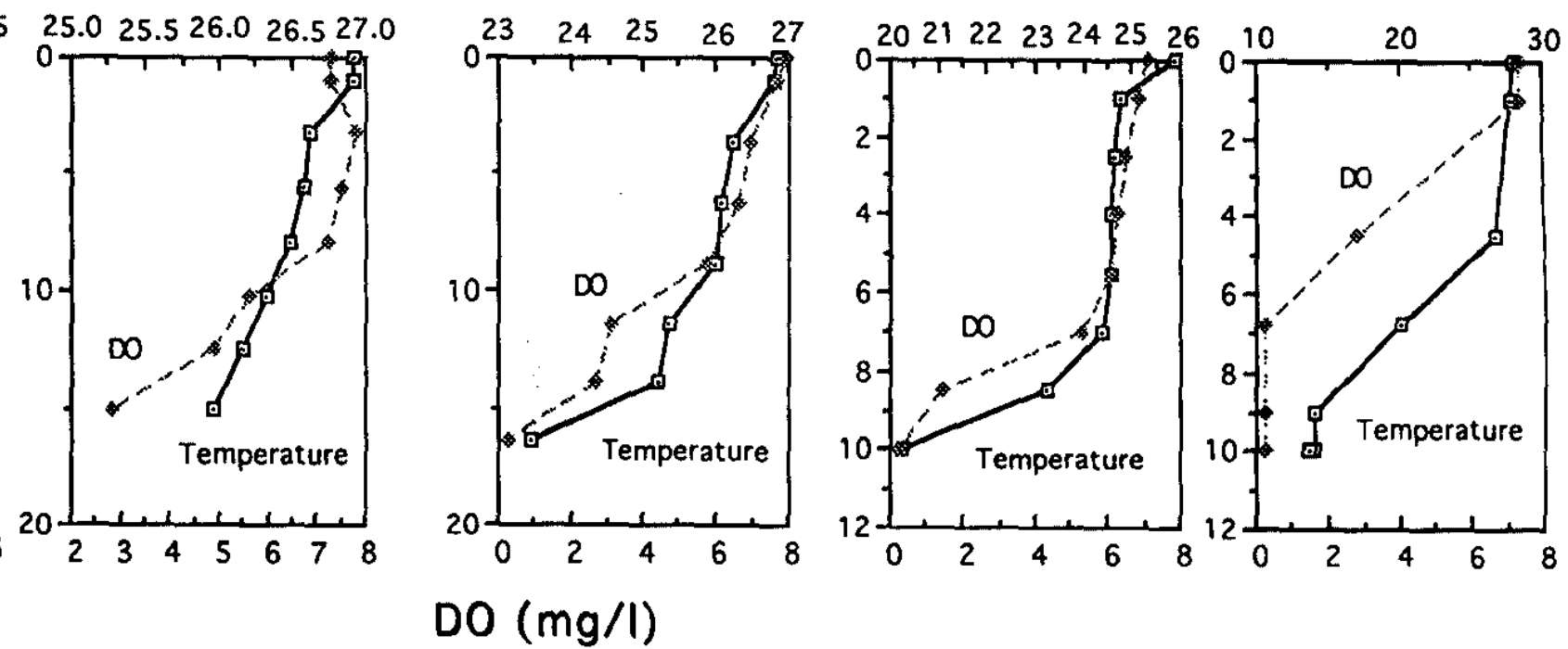


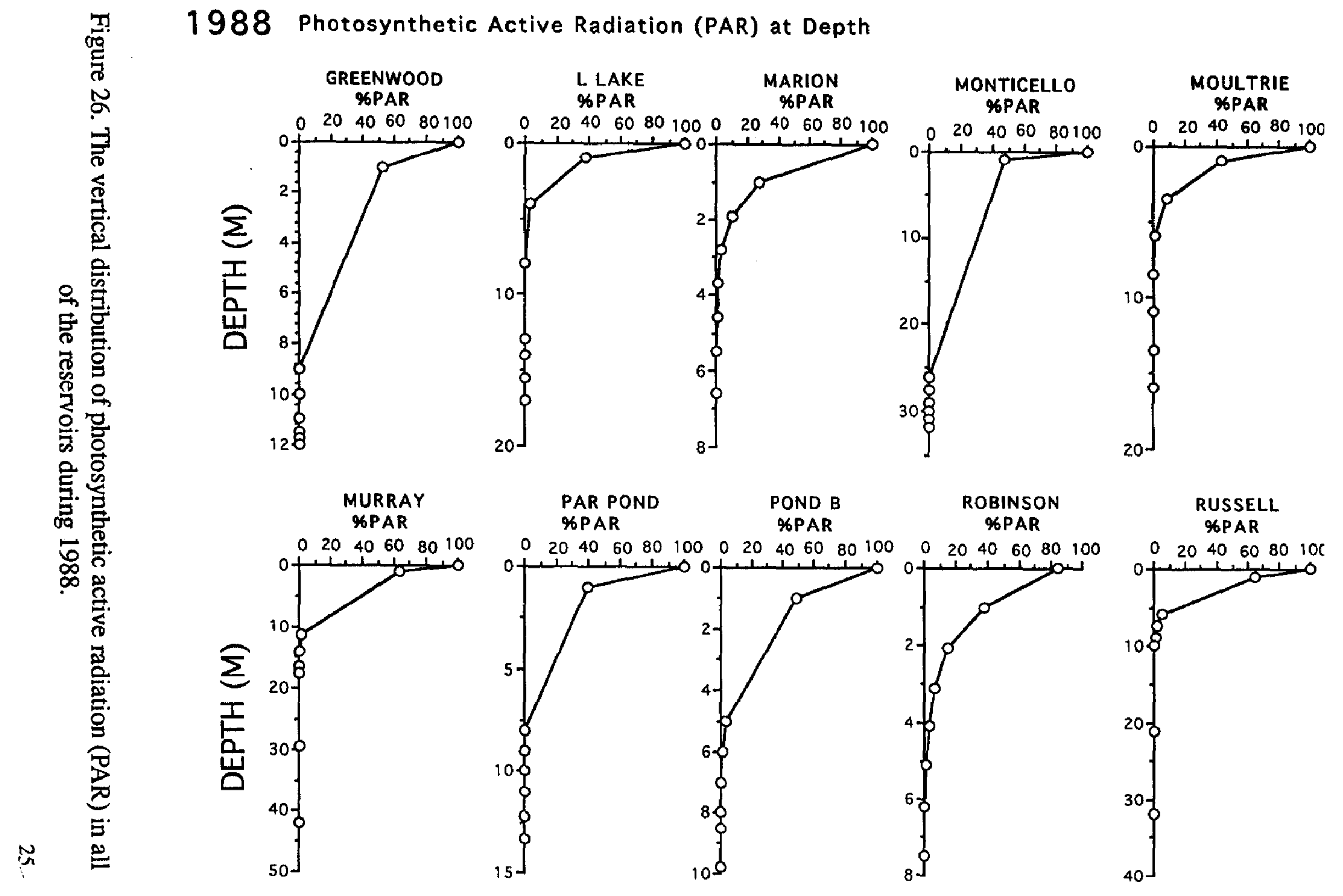


1989 Photosynthetic Active Radiation (PAR) at Depth

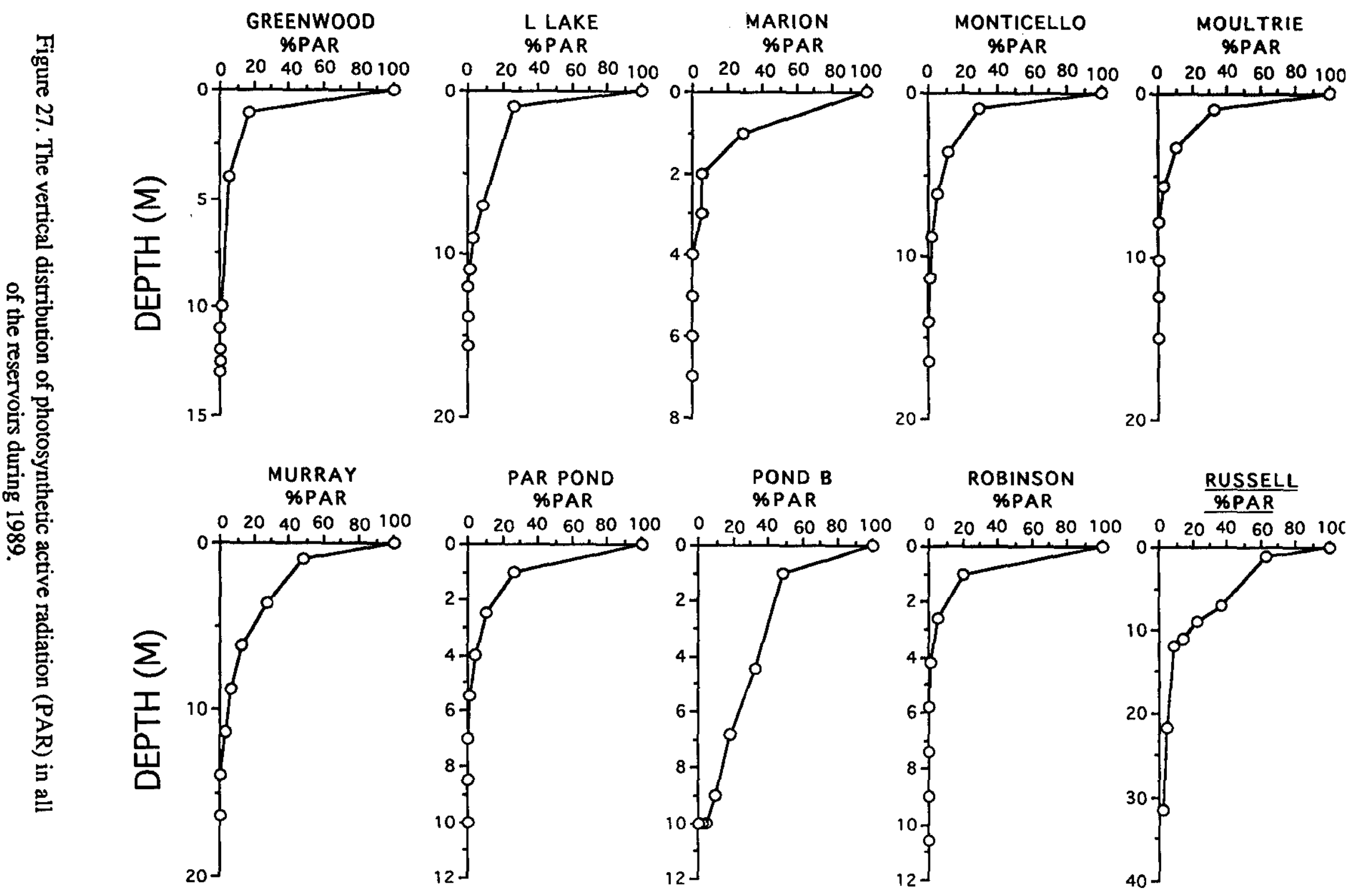



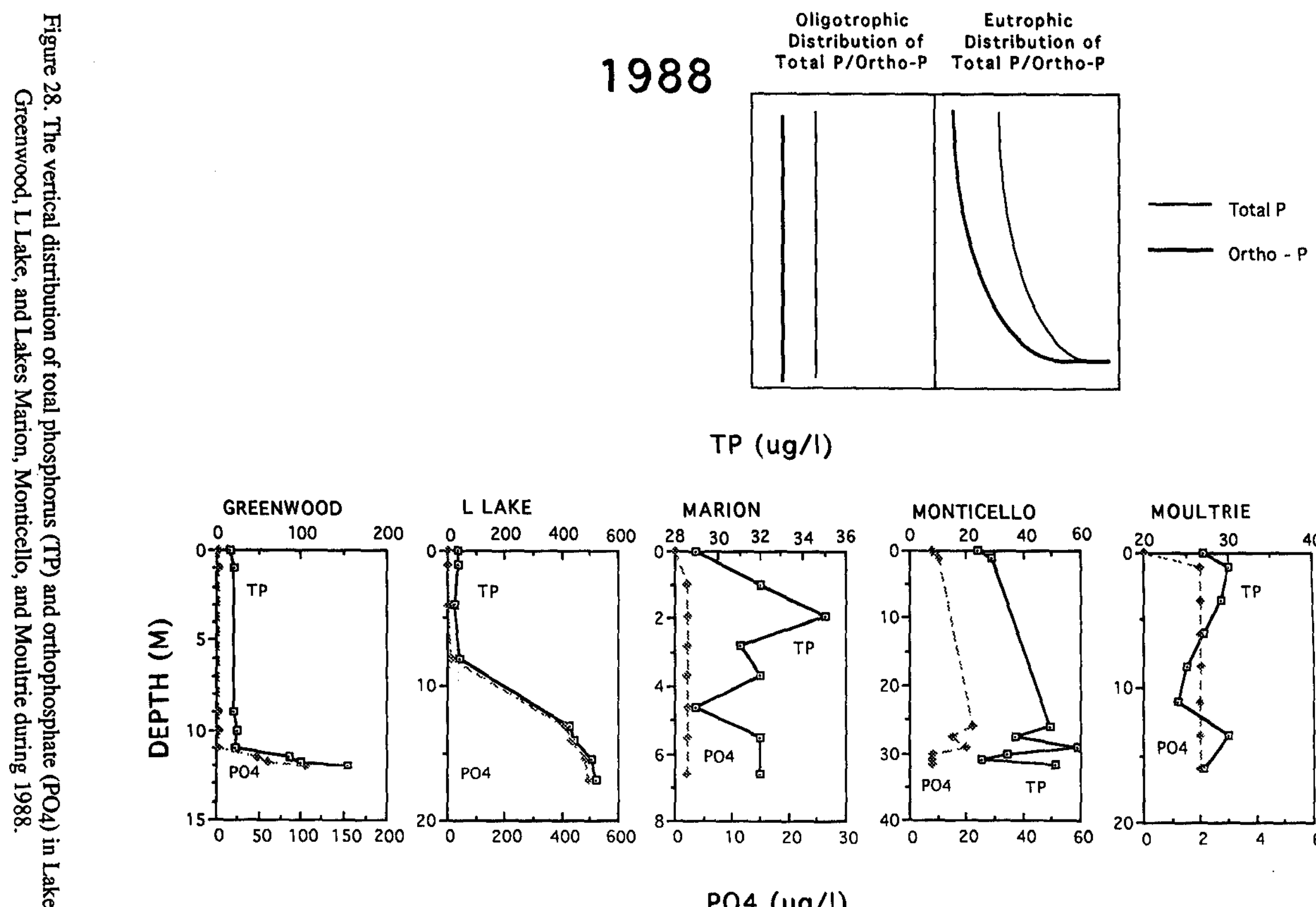

TP (ug/l)
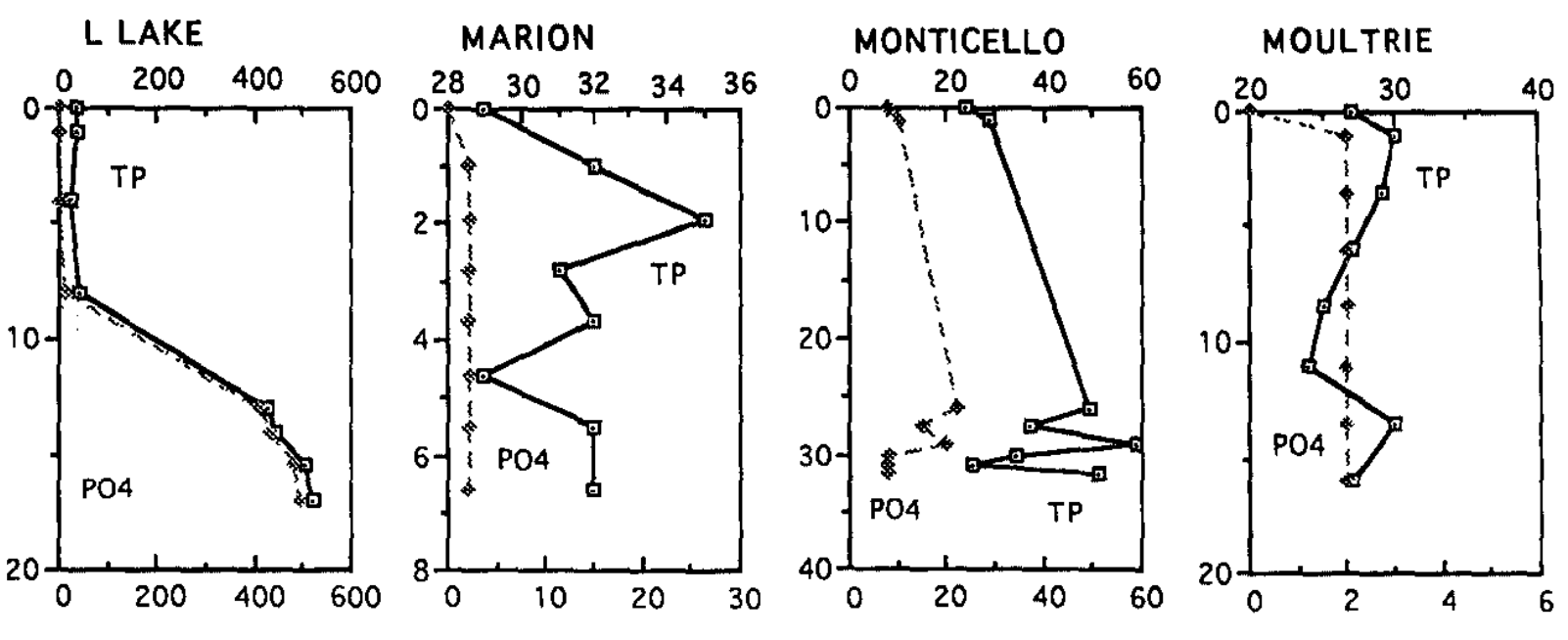

P04 (ug/l) 

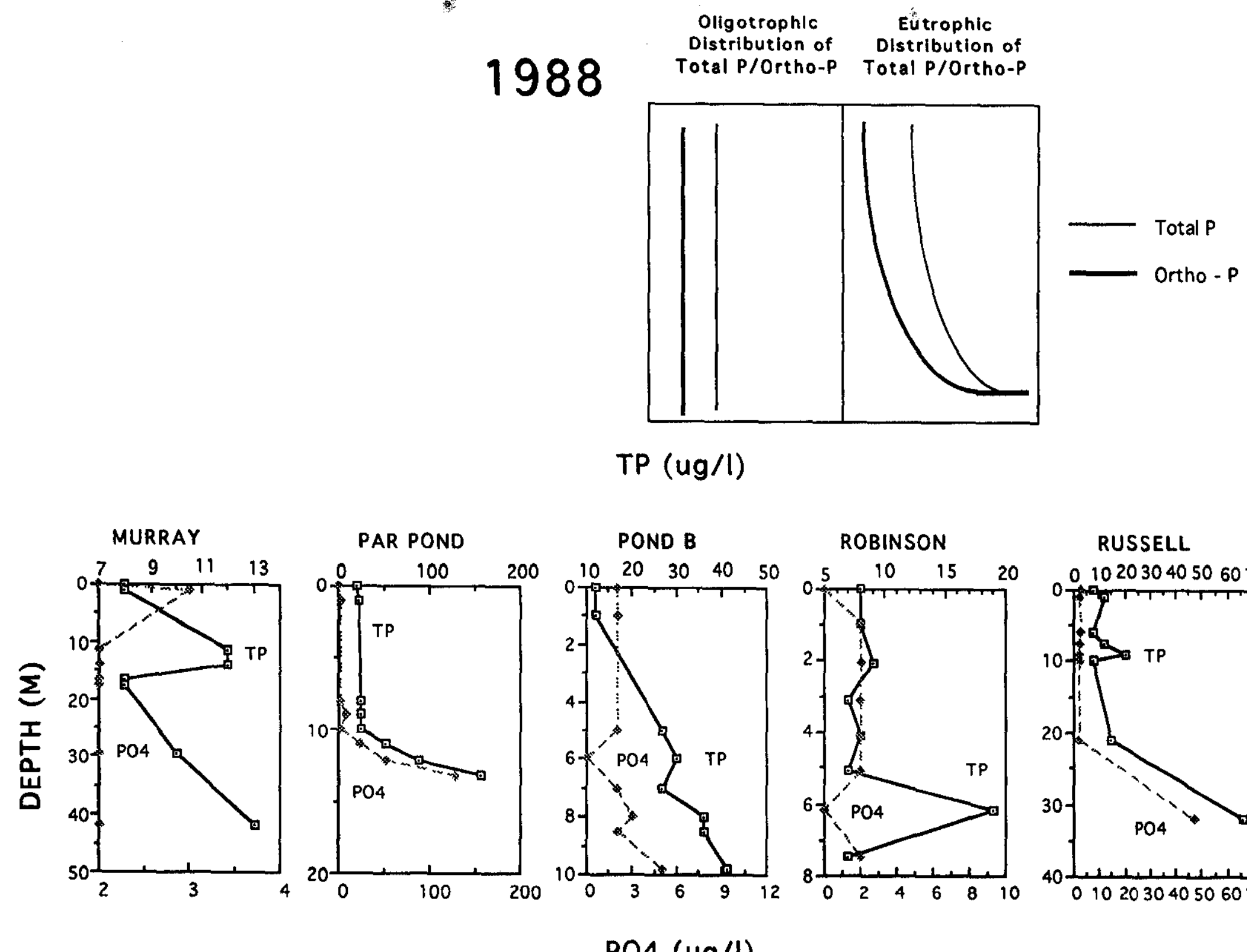

RUSSELL

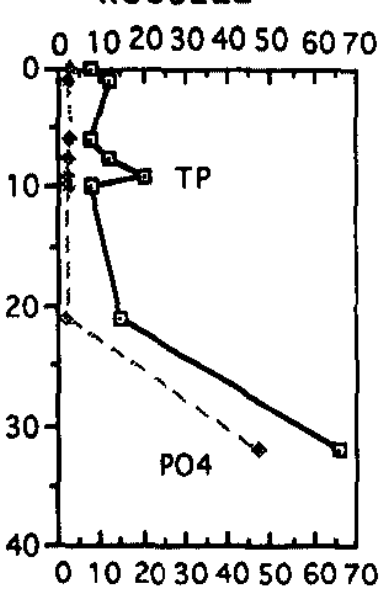

PO4 (ug/I) 

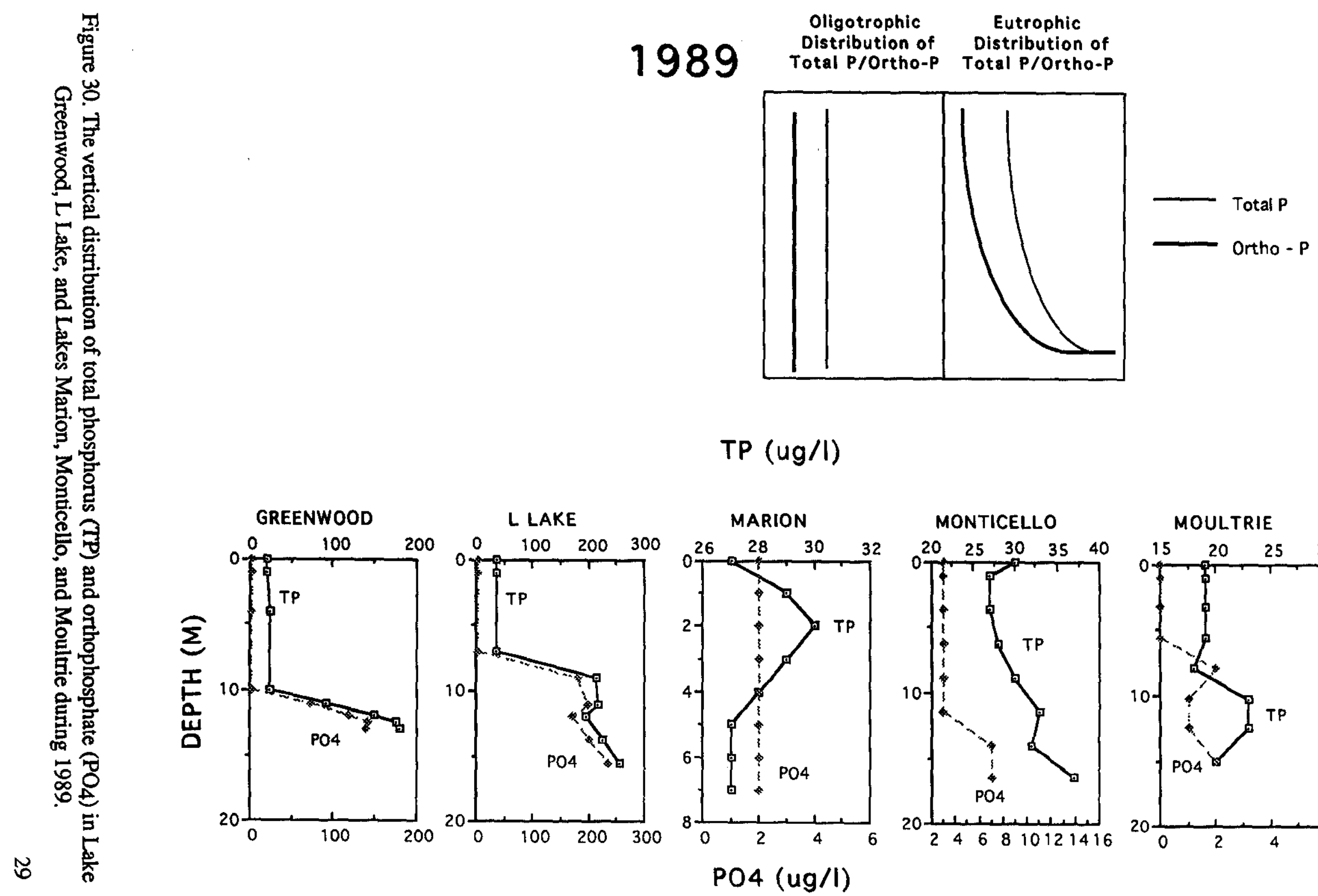

TP (ug/l)
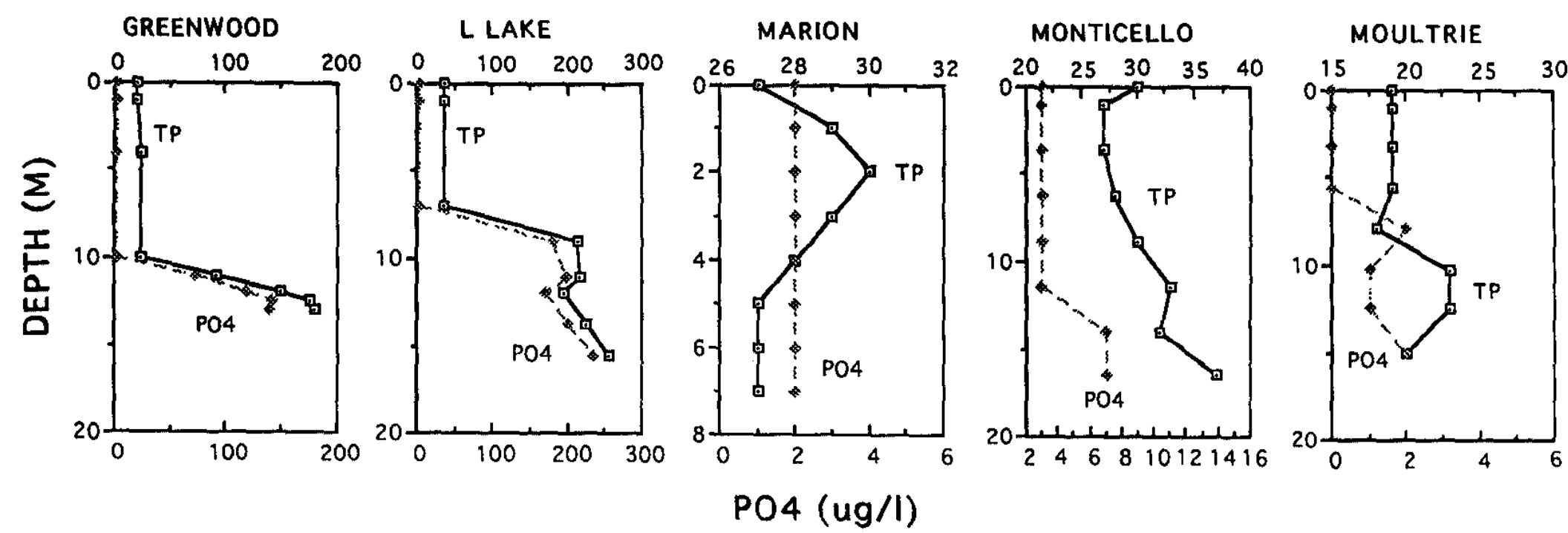

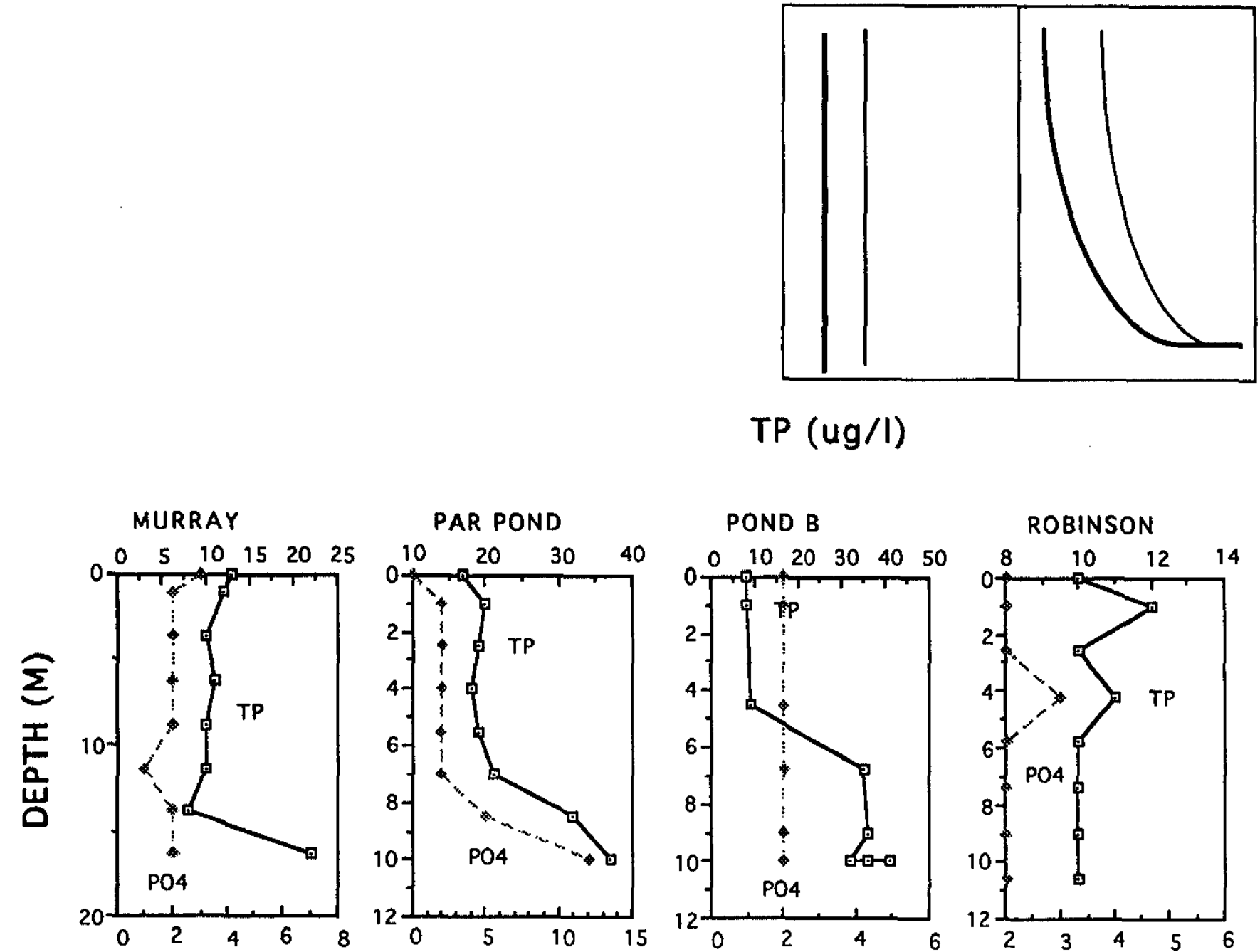

RUSSELL

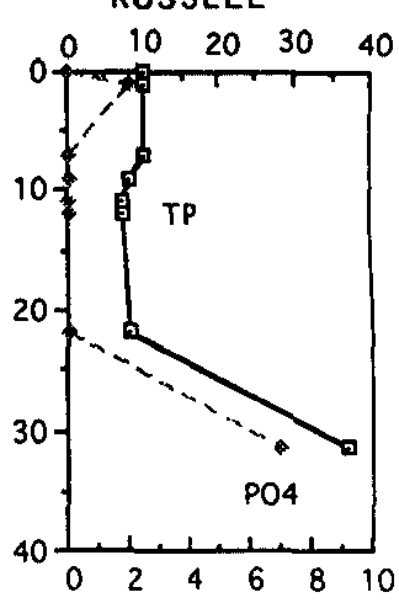

P04 (ug/l) 


\section{Lake Biota: Species Richness and Relative Abundance}

All of the above Regional Lakes assessments have focused exclusively on physical and chemical magnitudes, their variances, and their distributions.

The reasons for this approach are twofold. Synoptic lake surveys, are by nature, not designed for sampling biota, which requires extensive field and laboratory time and effort. Additionally, space and time scales mandate a completely different sampling design tailored to reproductive and life-table features of each group of plants and animals. For example, adequate studies of protozoan or rotifer dynamics require extended sampling frequencies at two to three-day intervals at several discrete depths at several in/offshore locations. Regional surveys over broad geographical areas cannot possibly encompass these stringent sampling needs (Steele 1989). Therefore, the biotic sampling performed during the Regional Lakes Study was designed only to minimally estimate species numbers which are increasingly becoming recognized for their ecosystem-stress predictive value (Schindler 1990) and estimate during a very brief time period the absolute and relative abundance of those species. Their value in this study in significantly increased by having absolute continuity in the sampling, sorting, and enumeration/taxonomic process, uncommon to studies of this type.

Phytoplankton taxa richness (Figure 32) indicated a range typical to reservoirs of the southeastern United States. In particular $L$ Lake numbers were comparative to Lakes Marion, Murray, Pond B, Robinson, and

Russell. Density estimates (Figure 33) indicate very high cell concentrations in Lakes Marion and Murray. Figures 34 and 35 indicate blue-green densities that are not the preferred prey for herbivorous zooplankton and fish. The data here represent only total numbers. High relative concentrations in most lakes are due to cyanobacteria picoplankters whose role in pelagic food webs in now only being discovered (Stockner 1988). High proportions $(>50 \%)$ of bluegreen algae occurred in L Lake, Par Pond, and Pond B in 1988, and all but Lakes Robinson and Russell in 1989. High densities of known nuisance species occurred in L Lake.

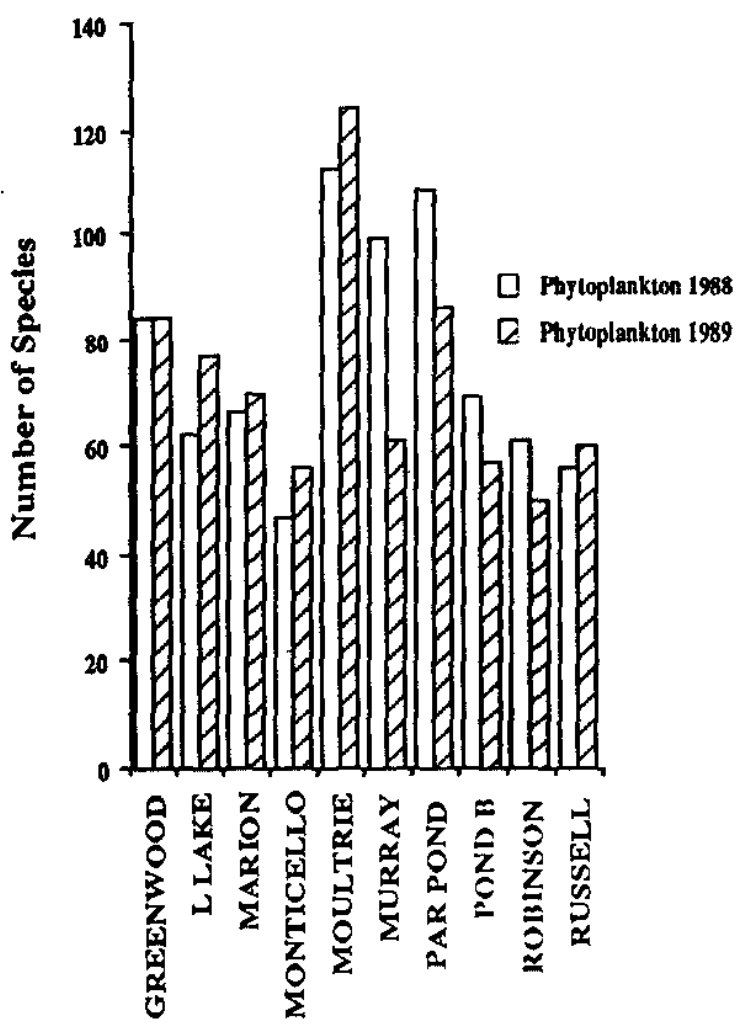

Figure 32. Phytoplankton species richness (number of species) in the ten reservoirs during 1988 and 1989.

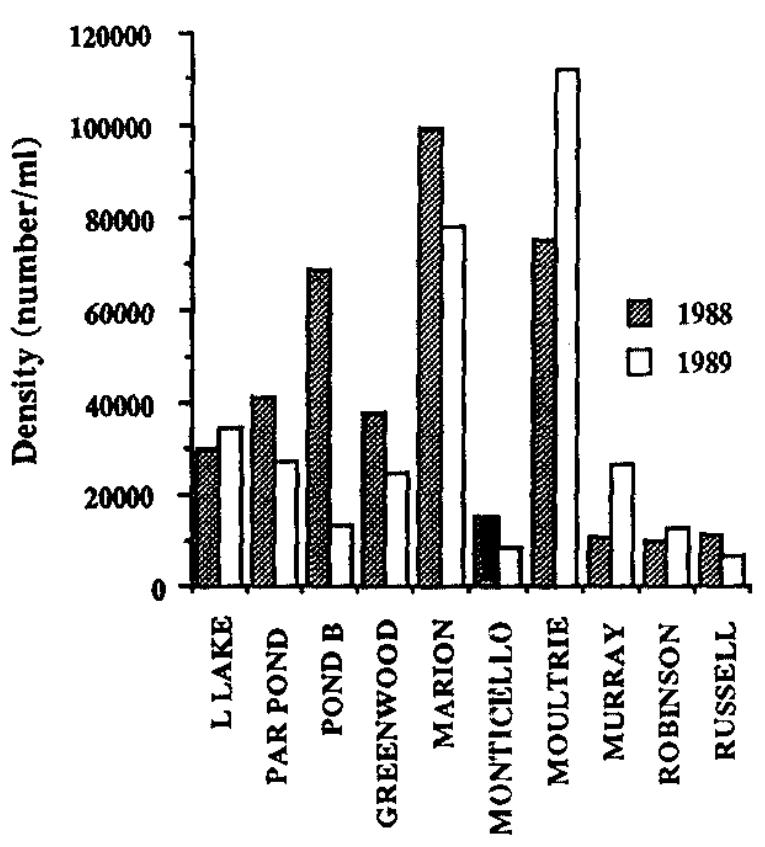

Figure 33. Total cell densities of phytoplankton in the ten reservoirs during 1988 and 1989. 


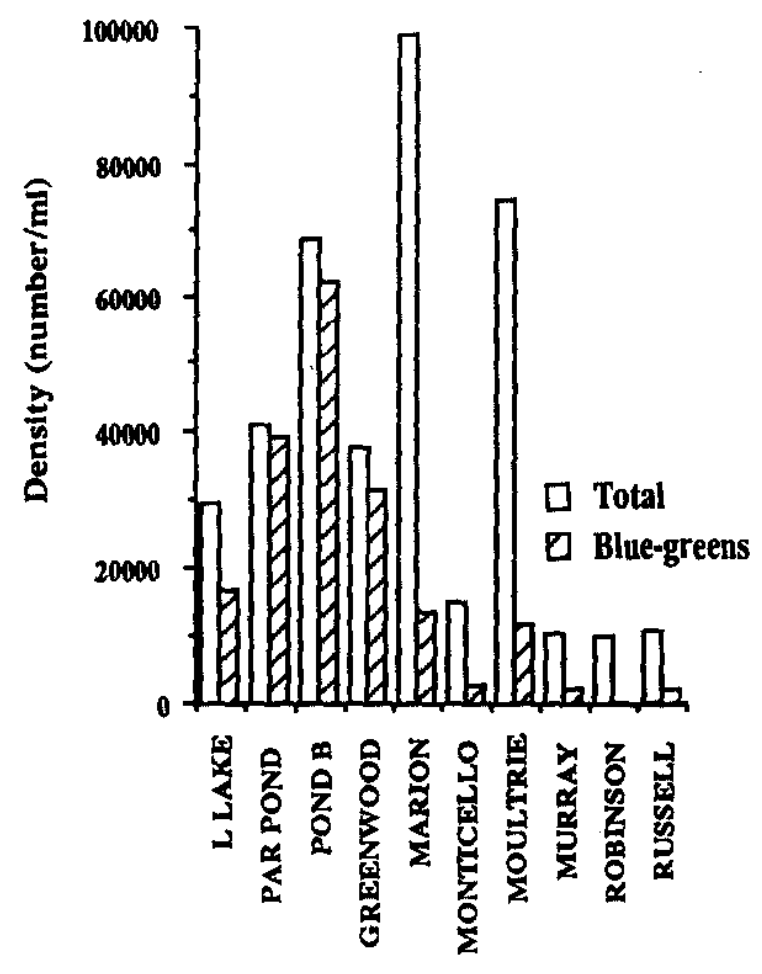

Figure 34. Comparison of total and blue-green densities of algae in the ten reservoirs during 1988.

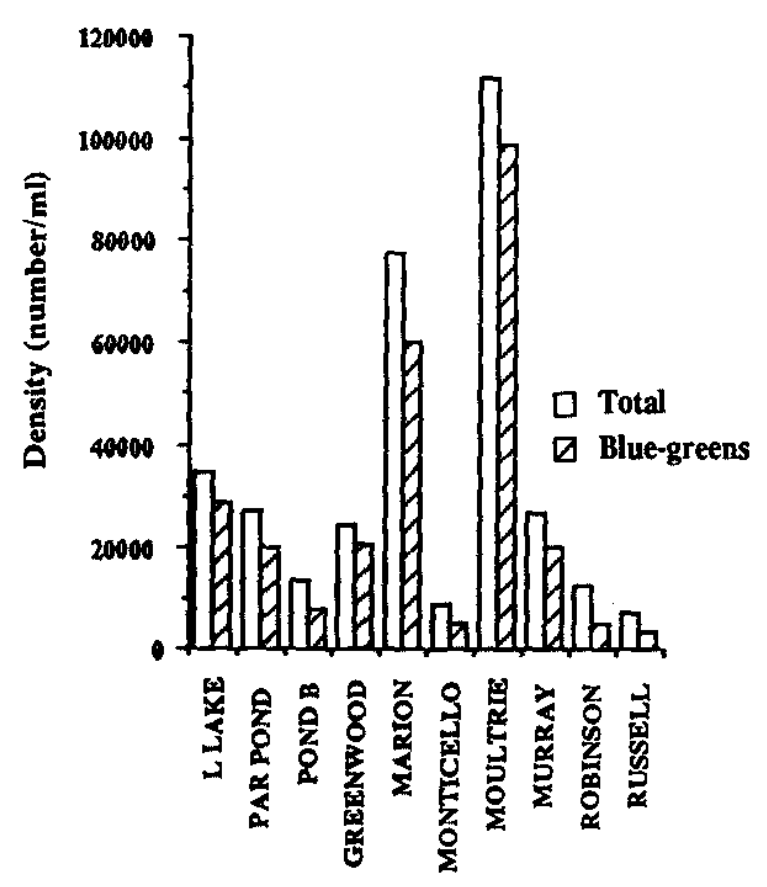

Figure 35. Comparison of total and blue-green densities of algae in the ten reservoirs during 1989.
Microzooplankton, until the work on microbial looping in pelagic communities (Porter et al. 1979; GeertzHansen et al. 1987), has traditionally been a neglected group. In freshwater systems they are represented principally by protozoans and the Rotifera (Hutchinson 1967). There are few studies on the occurrence of microzooplankton in the southeastern United States with historical population data on the Region Lakes reservoirs nonexistent. During the 1988 field year, depth integrated samples were collected for these groups. Taxa richness (Figure 36) was greater for the protozoans in Lakes Marion and Murray and lowest in Lake Robinson. The remaining basins had similar numbers. Rotifer taxa richness values were greatest in Lake Marion and similar in the remaining lakes. No single basin had unusually large or few species.

Protozoan abundances (Figure 37) were greatest in Lake Marion and Greenwood and lowest in Lakes Robinson and Russell. Variations within basins were again less than the observed between lake variations. All lakes had abundances of Uronema and Strombidium greater than 1000 individuals $/ \mathrm{ml}$. Total densities of offshore protozoans were significantly greater than other regional lakes (Hutchinson 1967; Chimney 1988).

Lake Marion also contained the highest densities of rotifers (Figure 37). Only Lake Moultrie and Pond B had comparable concentrations. The three dominant genera of rotifers in all reservoirs were Polyarthra, Keritella, and Trichocerca, all loricate species known for their resistance to cyclopoid and diaptomid predators (Stemberger 1979, 1985). All three species are herbivorous, respectively selecting diatoms and chysomonads (Pourriot 1977) and desmids (Pourriot 1970). 


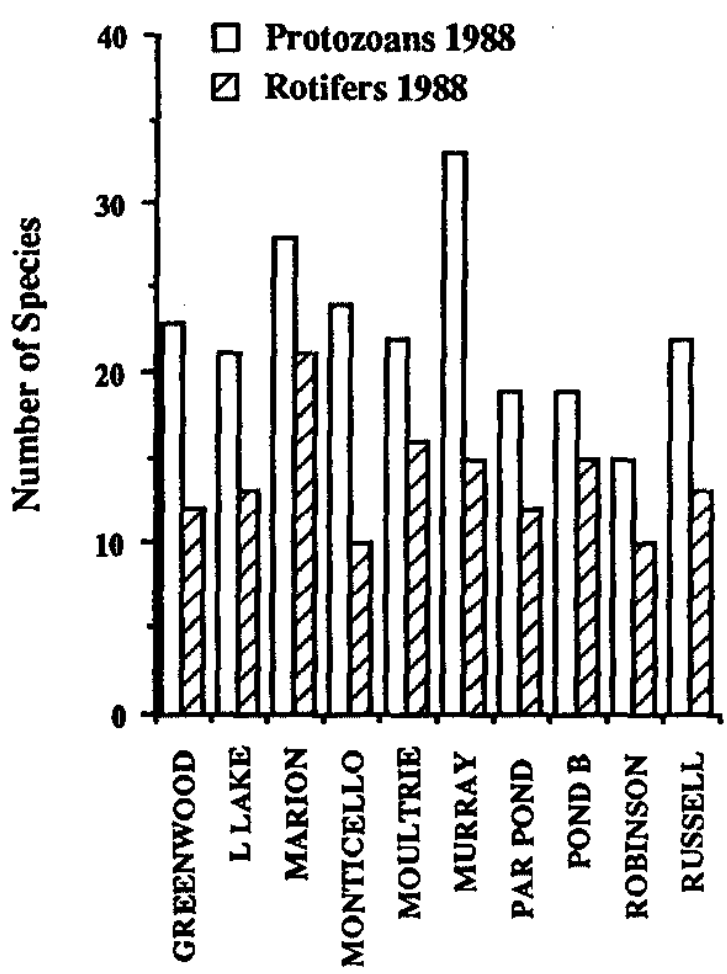

Figure 36. Protozoan and Rotifer species richness (number of species) in the ten reservoirs during 1988.

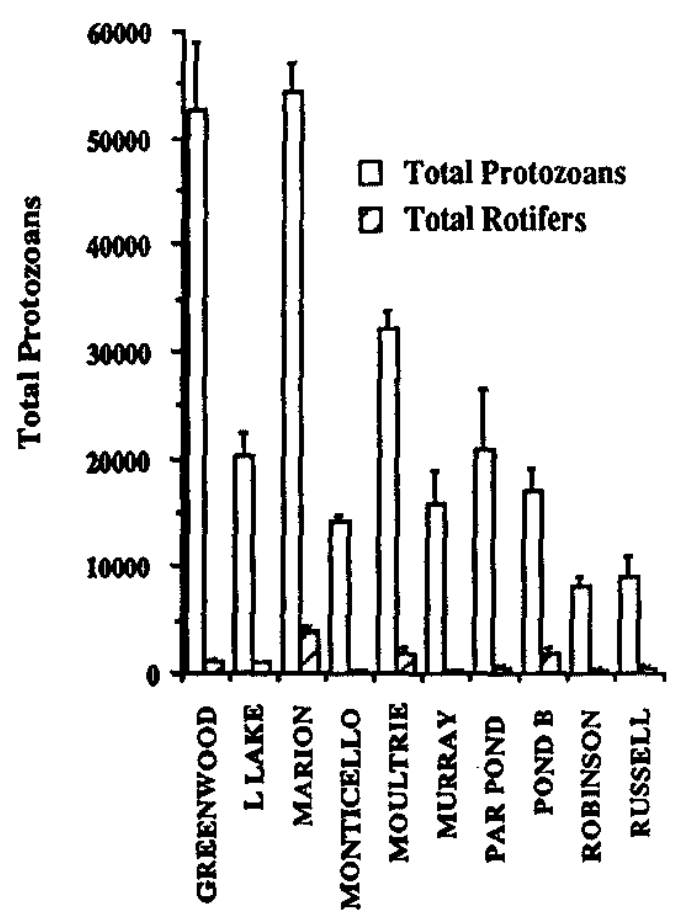

Figure 37. Total Protozoan and Rotifer densities in the ten reservoirs during 1988.
The number of species of crustacean macrozooplankton was variable between the two years' samplings (Figure 38). In 1988 Lakes Greenwood, Monticello, Moultrie, and Russell contained the greatest number of species, and in 1989 L Lake, Par Pond, and Lake Russell contained the greater number. Values ranging from 8 to 24 species are typical of smaller limnetic communities, but significantly lower than very large lakes (Hutchinson 1967). Abundances (Figure 39) during 1988 and 1989 were distinctly greater in Pond B, Lake Robinson, and $\mathrm{Par}$ Pond. These greater densities primarily result from higher phytoplankton densities suitable for food and the lack of effective planktivorous predation from shad populations (see Kerfoot and Sih 1987). Cladocera were plotted separately with the totals because they are the principle herbivores in lakes and their presence is a good barometer of planktivory. Cladoceran abundances were partially correlated to total zooplankton concentrations. Several field studies have documented the inverse correlation between cladoceran abundances and the percentage of blue-green species (Gliwicz 1969). Figures 40 and 41 illustrate the relationship between these two groups. During 1988 the inverse correlation was significant $(r=-0.51, P \leq 0.05)$, while during 1989 the relationship did not exist $(r=-0.012, P>0.10)$. It is noteworthy that this relationship was detectable for even a single year's survey having only a single days sampling at each lake.

Samples for taxa richness were collected at a larger number of stations during 1989 which is reflected in the greater species richness (Figure 42). Par Pond, Pond B, and Lake Robinson had the greatest number of species, while Lakes Greenwood and Russell had the fewest numbers. Macroinvertebrate densities (Figures 43 and 44) varied threefold during 1988 with Par Pond, Pond B, and Lake Robinson having the greater abundances and Lake Monticello, Murray, and Moultrie the lowest densities. Three groups dominated the benthic fauna in 1988, oligochaete worms, the Dipteran midge Chaoborus, and the tribe Chironomini. Lakes Marion, Moultrie, and Russell had the greatest densities of Oligochaeta. Chaoborus were very abundant in Par Pond and Pond $\mathrm{B}$. This genus is a voracious ambush predator on cladocerans that may account for low cladoceran abundances in those basins having significant populations (Federenko 1973; Federenko 1975; Lewis 1977). In 1989 abundances were significantly lower in all the lakes except L Lake and Par Pond which had significant densities of oligochaetes. Problem species were present in a few lakes. Lakes Greenwood and Marion contained moderate numbers in 1989 (Lake Greenwood $-409 / \mathrm{m}^{2}$; Lake Marion- $1091 / \mathrm{m}^{2}$ ) of the clam Corbicula which is known for fouling water and power plant intake structures. 
L Lake was different from all other lakes in having very high densities of Chironomus $\left(19262 / \mathrm{m}^{2}\right)$. All other lakes had concentrations an order of magnitude lower than in L Lake. Chironomid populations fluctuate over two to three-week time frames with several species appearing and then disappearing through the summer months (Lauritsen 1990).

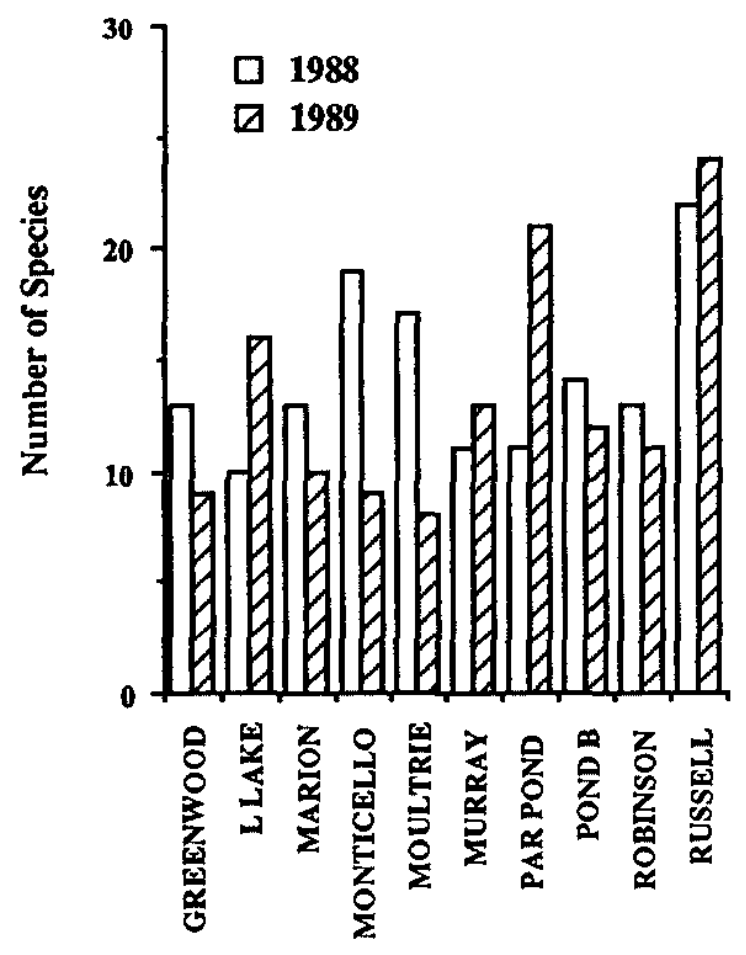

Figure 38. Macrozooplankton species richness (number of species) in the ten reservoirs during 1988 and 1989.

\section{CONCLUSIONS}

Most of this study emphasized water quality variables which characterize aquatic synoptic surveys. They document the important physical and chemical boundary conditions for a lake's biotic communities.

The longitudinal transects study indicated that variation within lakes for any parameter was small compared to between lake variation. This result implies that there were no significant changes in water mass for any of the basins during sampling. Furthermore, it indicates that variations in the biological results were more likely due to biological processes and interactions rather than physical or chemical effects. The transect results also indicate that several sampling stations located along the longitudinal axis of the basin will adequately represent the whole water body. This traditional approach saves time, effort, and money.
Several conclusions are reached from the magnitudes and distributions of the water quality variables. Alkalinity combined with $\mathrm{pH}$ estimates indicate that all of the basins tend to be softwater lakes, particularly Lake Robinson and Pond B. Phosphorus and nitrogen concentrations in L Lake, Lake Marion, Lake Greenwood, and Lake Monticello are indicative of eutrophic systems. Additionally, the vertical water quality profilcs also indicate that South Carolina reservoirs reflect varying degrees of cultural eutrophication.

The indicators of eutrophication used in this study have been widely employed and historically have not been completely successful. Only total phosphorus has been consistent indicator for lakes of all types at all latitudes. TP was a good indicator of algal biomass. The clustering analyses based on all of the variables further supported the above conclusions. These findings suggest three groupings of the ten lakes based on water quality parameters. Pond B and Lake Robinson are clearly very softwater systems well separated from the other eight basins. Par Pond, Lake Moultrie, Lake Murray, and Lake Russell are meso/eutrophic basins with moderate problems of nutrient enrichment. L Lake, Lake Marion, Lake Greenwood, and Lake Monticello have nitrogen and phosphorus concentrations that definitively categorize them as eutrophic systems.

Interpretations from the biotic samplings should be recognized within the context of seasonal succession because each lake was sampled on a single day for each year. The results reported here represent only midsummer conditions which was chosen because this period represents extended thermal stratification with all of its physical, chemical, and biotic consequences. Absolute and relative abundances of phytoplankton, zooplankton and many of the benthic invertebrates have life histories are highly variable over very short time frames from days to weeks.

These results are good indicators of general conditions. Taxa richness for phytoplankton, zooplankton, and the benthos was not significantly different from lake to lake in either 1988 or 1989 . Within this construct phytoplankton and zooplankton populations are not significantly different from one another in any of the lakes. All the basins contained primary producer communities composed of mainly green and blue-green species. Diatoms and green species so characteristic of most temperate oligotrophic lakes and reservoirs was not observed here. Zooplankton populations, though very similar to each other are very different from other regional areas. None of the lakes contained a single population of a large cladoceran species. This results from two processes, size-selective fish predation and the latitudinal effect of the region on zooplankton growth. 
Total Macrozooplankton and Cladocera Abundances 1988

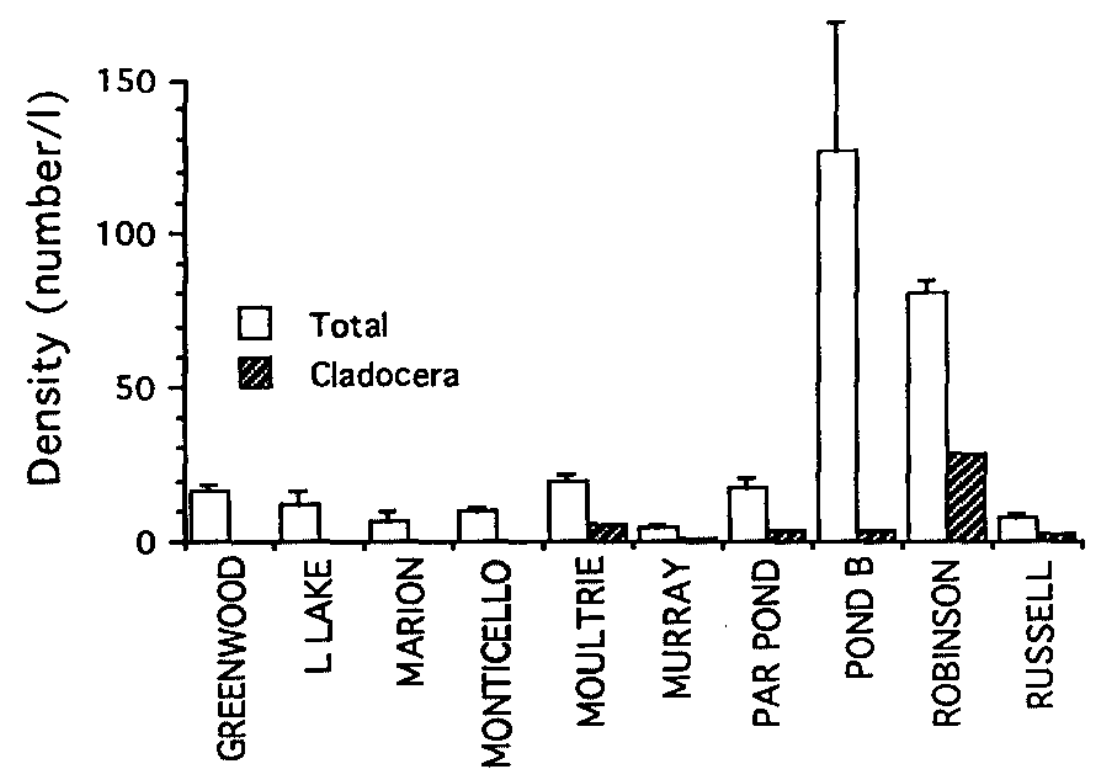

Total Macrozooplankton and Cladocera Abundances 1989

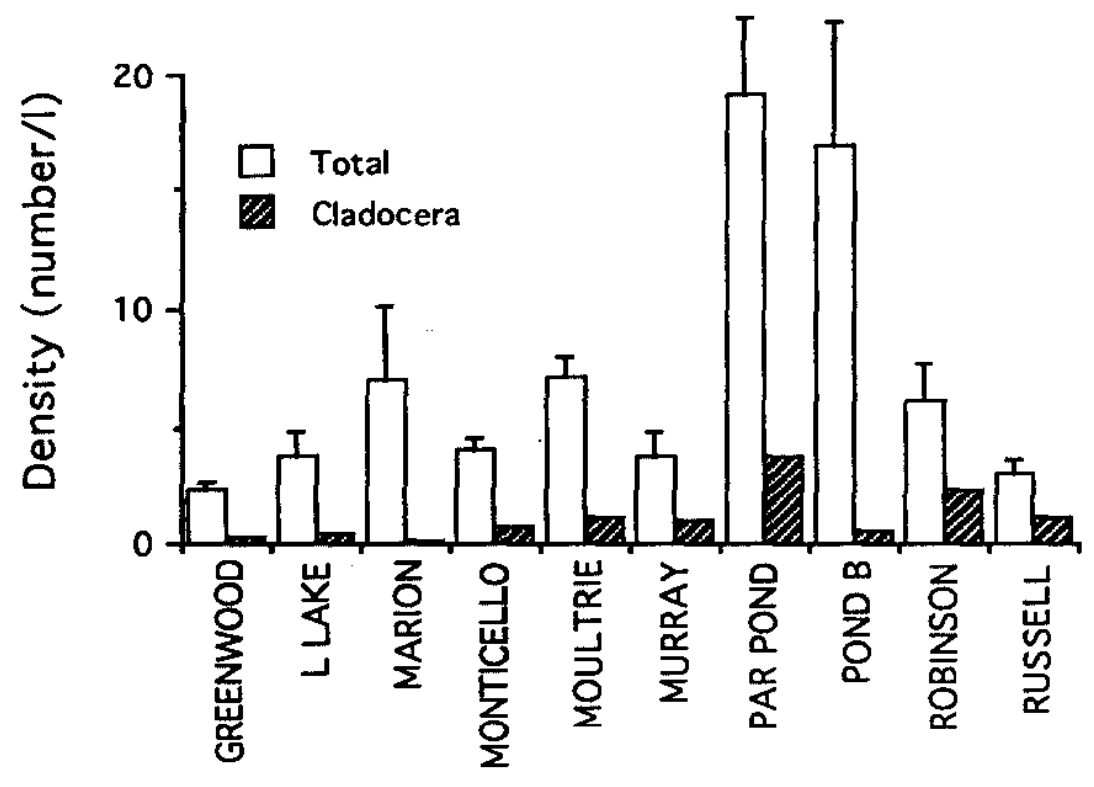

Figure 39. Comparison of total macrozooplankton and Cladocera densities during 1988 and 1989. 
Total Macroinvertebrate Abundances 1988

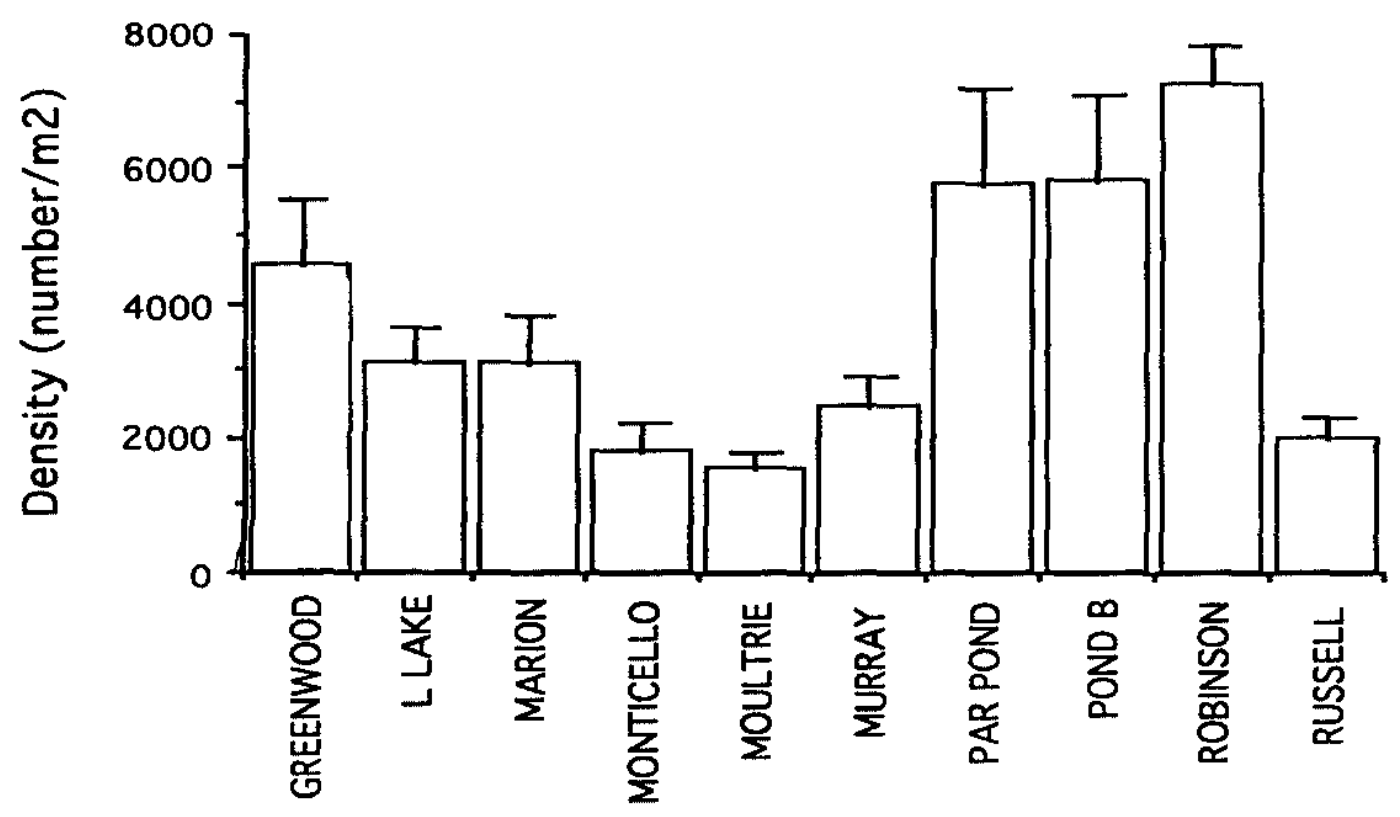

Per Cent Abundances of

Oligochaeta, Chaoborus, \& Chironomini

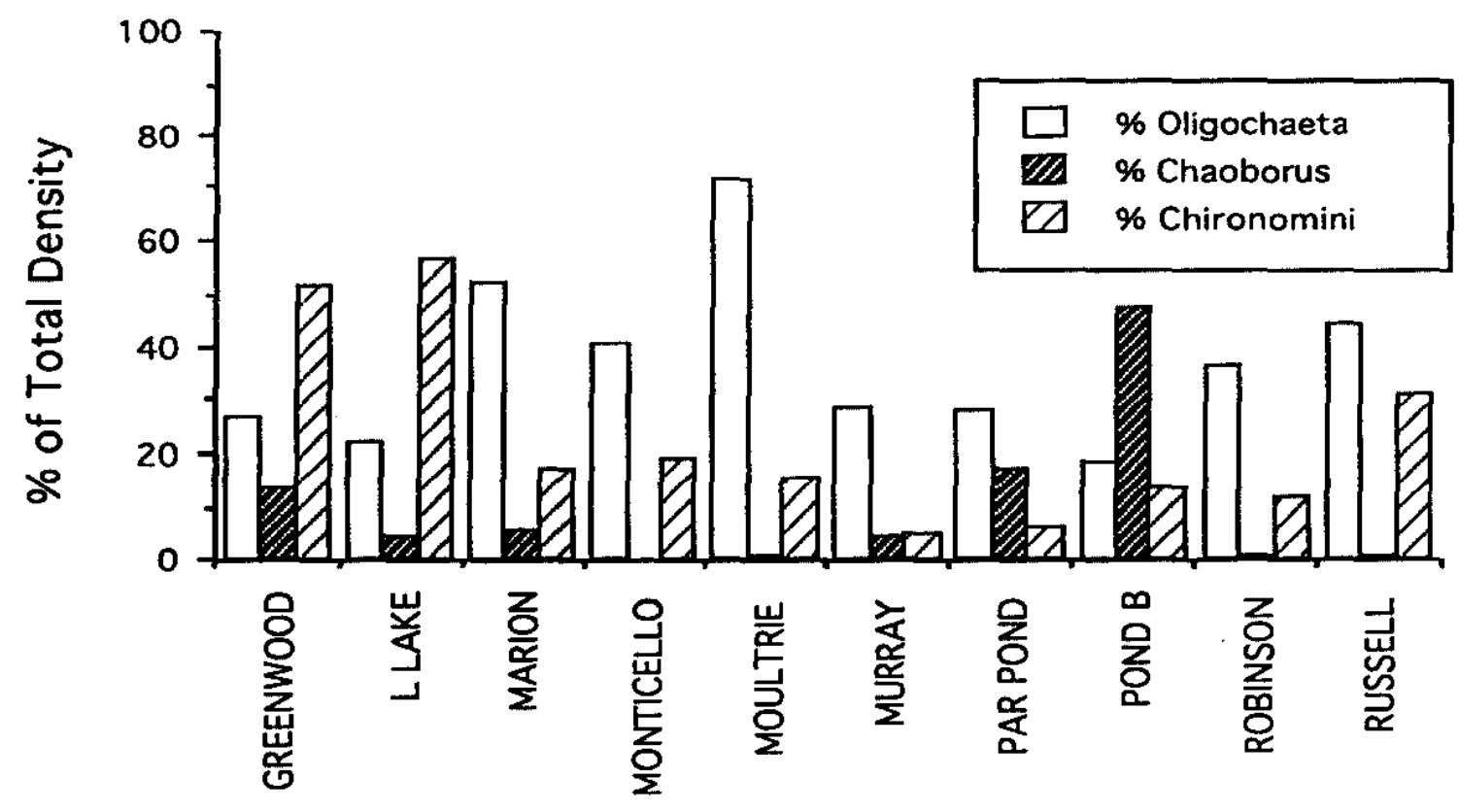

Figure 43. Total macroinvertebrate densities and per cent abundance of Oligochaeta, Chaoborus, and Chironomini during 1988. 

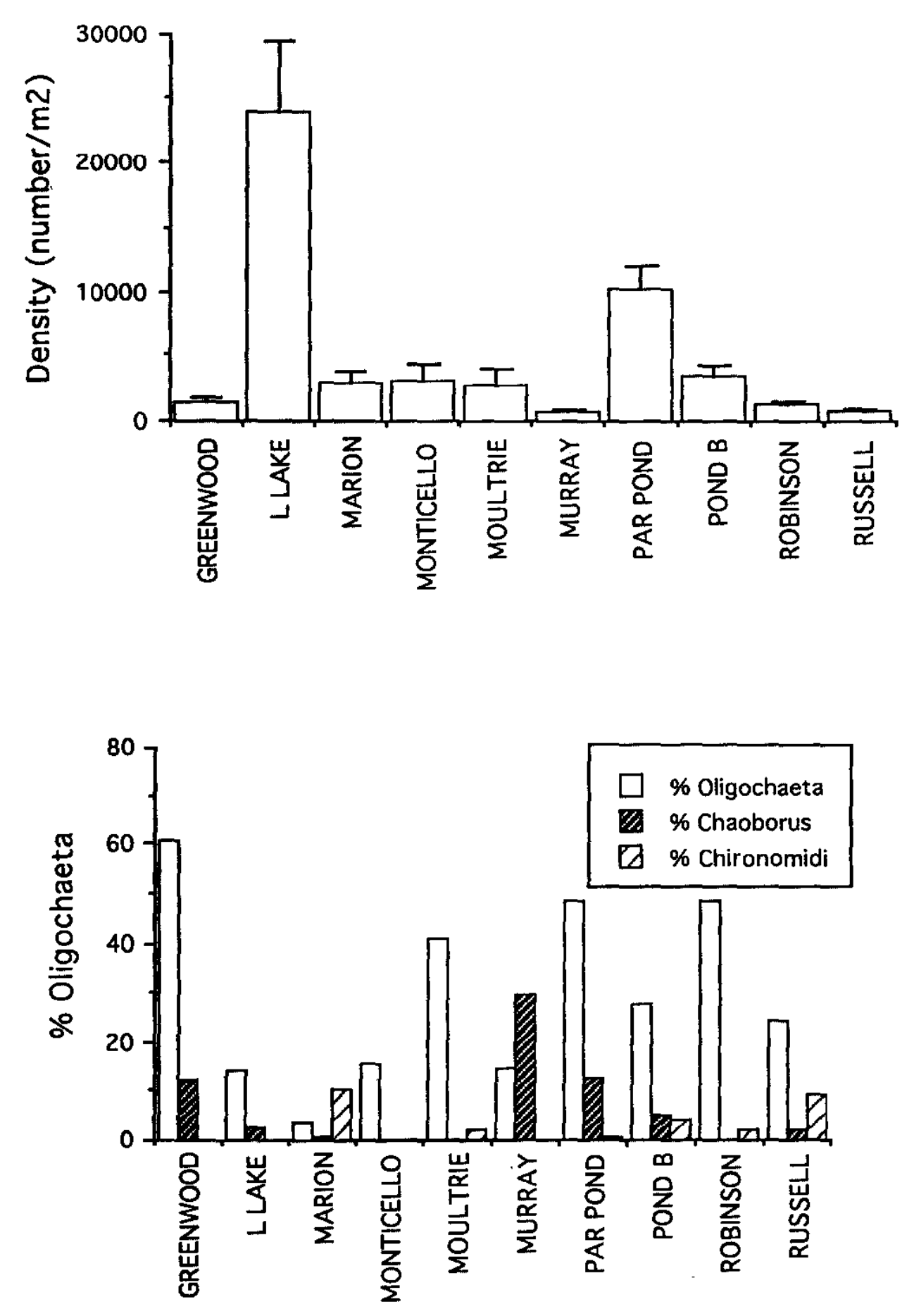

Figure 44. Total macroinvertebrate densities and per cent abundance of Oligochaeta, Chaoborus, and Chironomini during 1989. 
Planktivorous fish can drive a large Daphnia to extinction in a lake during a single summer. Added to predation increased temperatures accelerate growth rates and reduce the time between molts which results in a smaller sized population. The most diverse biotic community was the benthos. Macroinvertebrate faunas were characterized by high species number and differing dominant groups.

One of the main purposes of this study was to compare lakes throughout the state and at SRS to L Lake with regards to the $\mathrm{BBC}$ definitions. Pollution (thermally) tolerant species did not dominate any of these lakes communities. L Lake did contain high densities of Chironomus, but this population has not consistently appeared in the L-Lake benthic fauna (Lauritsen 1990). Species richness indicated similar biotic diversities for all lakes. Absolute abundances of phytoplankton, zooplankton, and benthos in L Lake do not suggest unusually high rates of productivity. All of the lakes tend to be eutrophic having greater productivity rates than true oligotrophic ecosystems. None of the sampled populations in the sampled reservoirs are maintained by repeated stocking and reseedings.

All trophic groups that would be expected in these lakes were present.

\section{REFERENCES}

Baxter, R. M. 1977. Environmental effects of dams and impoundments. Ann. Rev. Ecol. Sys. 8:255283.

Beaver, J. R. and T. L. Crisman. 1990. Seasonality of planktonic ciliated protozoa in 20 subtropical Florida lakes of verying trophic state. Hydrobiologia. 190:127-135.

Beaver, J. R. and T. L. Crisman. 1991. Temporal variability in algal biomass and primary productivity in Florida lakes relative to latitudinal gradients, organic color and trophic state. Hydrobiologia. 224:89-97.

Beeton, A. M. 1965. Eutrophication of the St. Lawrence Great Lakes. Limnol. Oceanogr. 10:240-254.

Carpenter, S. R., and J. K. Kitchell. 1984. Plankton community structure and limnetic primary production. Amer. Naturalist 124:159-172.
Carpenter, S. R., J. F. Kitchell, J. R. Hodgson, P. A. Cochran, J. J. Elser, M. M. Elser, D. M. Lodge, D. Kretchmern, and X. He. 1987. Regulation of lake primary productivity by food web structure. Ecology, 68:1863-1876.

Chimney, M.J., 1988. L-Lake Zooplankton; L-Lake/ Steel Creek Biological Monitoring Program January 1986-December 1987. Report No. ECS-SR-63. Prepared by Environmental \& Chemical Sciences, Inc. for E.I. duPont de Nemours and Company, Savannah River Laboratory, Aiken, SC.

COE. 1985. Water quality studies: Richard B. Russell and Clarks Hill Lakes. Us Army Engineer District, Savannah, GA 31402-0889.

COE. 1986. Water quality studies: Richard B. Russell and Clarks Hill Lakes. Us Army Engineer District, Savannah, GA 31402-0889.

CP\&L, 1980. H.B. Robinson Steam Electric Plant Environmental Monitoring Program 1979 Annual Report. Carolina Power and Light Company, Environmental Technology Section, Raleigh, NC.

Dames \& Moore, 1985. Environmental Monitoring Report January 1983-December 1984 for the Virgil C. Summer Nuclear Station for the South Carolina Department of Health and Environmental Control, Job No. 5182-108-09. Prepared for the South Carolina Electric \& Gas Company, Columbia, South Carolina.

Dugdale, R. C. 1967. Nutrient limitation in the sea: Dynamics, identification and significance. Limnol. Oceanogr. 12:685-695.

Dugdale, R. C. 1976. Nutrient cycles. In D. H. Cushing and J. J. Walsh, (eds.) The ecology of the seas. Saunders and Co. Philadelphia.

EPA, 1975. Water quality assessment: A screening procedure for toxic and conventional pollutants in surface and ground water-Part 1 (Revised 1985). EPA/600/6-85/002a. ERL/Athens, GA 30613.

EPA, 1976. Report on Lake Marion, Berkely, Calhoun. Clarendon, Orangeburg and Sumter Counties. South Carolina. EPA Region IV, Working Paper 434. Corvallis Environmental Reserarch Laboratory, Corvallis, Oregon 97330. 
EPA, 1977. Report on Lake Moultrie, Berkely County. South Carolina. EPA Region IV. Working Paper 435. Corvallis Environmental Research Laboratory, Corvallis, Oregon 97330.

Fedorenko, A. Y. 1973. Predation interactions between zooplankton and two species of Chaoborus (Diptera, Chaoboridae) in a small coastal lake. M. S. Thesis, Univ. British Columbia. 123p.

Federenko, A. Y. 1975. Feeding characteristics and predation impact of Chaoborus (Diptera, Chaoboridae) larvae in a small lake. Limnol. Oceanogr. 20:250-259.

Geertz-Hansen, O., M. Olesen, P. K. Bjomsen, J. B. Larsen, and B. Riemann. 1987. Zooplankton consumption of bacteria in a eutrophic lake and in experimental enclosures. Arch. Hydrobiol. 110:553-563.

Gliwicz, Z. M. 1969. Studies on the feeding of pelagic zooplankton in lakes with varying trophy. Ekologia Polska Series A. 17:663-708.

Hutchinson, G. E. 1957. A treatise on limnology. Vol. I, Wiley and Sons, London.

Hutchinson, G. E. 1967. A treatise on limnology. Vol. II, Wiley and Sons, London.

Inabinet, J. R. Water Quality Characteristics of the Sante Cooper Lake System: 1984. Prepared by the Santee Cooper Environmental Resources Division Water Quality Management Section, P.O. Box 398, Moncks Corner, SC (November, 1985).

Kennedy, R. H., K. W. Thornton, and D. E. Ford. 1985. Characterization of the reservoir ecosystem. In Microbial precesses in reservoirs, D. Gunnison. ed. Dr. W. Junk Publ., Dordrecht.

Kerfoot, W. C., and A. Sih. 1987. Predation: Direct and indirect impacts on aquatic communities. Univ. Press of New England, Hanover, NH.

Kimmel, B. L., and A. W. Groeger. 1986. Limnological and ecological changes associated with reservoir aging. In G. E. Hall and M. J. Van Den Avyle, (eds.), Reservoir Fisheries management: strategies for the ' 80 's. Amer. Fish. Soc. pp. 103-109.
Kimsey, C.D, A.C. Boozer, J.N. Knox, L.E. Turner, K.K. Cain, and G.W. Long. 1982. South Carolina Clean Lakes Classification Survey. Technical Report No. 019-82. South Carolina Department of Health \& Environmental Control

Lauritsen, D. 1990. L-Lake Macroinvertebrates: L-Lake/ Steel Creek Biological Monitoring Program January 1986 - December 1989. Normandeau Associates Inc., P.O. Box 1393, Aiken, SC. Draft report to WSRC, DOE-SR.

Lewis, W. M. 1977. Feeding selectivity of a tropical Chaoborus population. Freshwater Biol. 7:311325.

Mortimer, C. H. 1974. Lake hydrodynamics. Mitt. Int. Ver. Limnol. 20:124-197.

National Academy of Sciences. 1969. Eutrophication: Causes, consequences, correctives. Proceedings of a symposium, Washington, D. C.

Odum, H. T. 1985. Trends expected in stressed ecosystems. Bioscience 35:419-422.

Patterson, G.G. and T.W. Cooney. 1986. Sediment Transport and Accumulation in Lakes Marion and Moultrie, South Carolina. Pages 13361345 in Proc. of the Third International Symposium on River Sedimentation, Oxford, MS, March 31-April 4, 1986.

Porter, K. G., M. L. Pace, and J. F. Battey. 1979. Ciliate protozoans as a link in freshwater planktonic food chains. Nature 227:563-564.

Pourriot, R. 1970. Quelques Trichocerca (Rotiferes) et leurs Regines Alimentaires. Ann. Hydrobiol. 1:155-171.

Pourriot, R. 1977. Food and feeding habits of Rotifera. Arch. Hydrobiol. Beih. 8:243-260.

Reckhow, K. H. 1988. Empirical models for trophic state in southeastern U. S. lakes and reservoirs. Water Res. Bull. 24:723-734.

Rigler, F. H. 1964. The phosphorus fractions and turnover time of inorganic phosphorus in different types of lakes. Limnol. Oceanogr. 9:511-518. 
Rigler, F. H. 1966. Radiobiological analysis of inorganic phosphorus in lakewater. Proc. Int. Assoc. Theor. Appl. Limnol. 16:465-470.

Rigler, F. H. 1968. Further observations inconsistent with the hypothesis that the molybdenum blue method measures orthophosphate in lakewater. Limnol. Oceanogr. 13:7-13.

Rigler, F. H. 1973a. A dynamic view of the phosphorus cycle in lakes, pp. 539-572. In E. J. Griffith, A. Beeton, J. M. Spencer, and D. T. Mitchell (eds.), Environmental phosphorus handbook. Wiley and Sons, Inc., New York.

Rigler, F. H. 1973b. Feeding rates. pp. 228-254, In W. T. Edmondson and G. G. Vinberg (eds.), A Manual on methods for the assessment of secondary productivty in fresh waters. Blackwell Sci. Publ. Oxford.

SCDHEC, 1981. Water Quality Assessment, Union Camp Project. Bureau of Watewater and Stream Quality Control. Columbia, SC 29230.

SCWRC. 1974. Inventory of lakes in South Carolina ten acres or more in surface area, S. C. Water Resources Commission Rt. No. 119, Columbia, SC, 222p.

Schindler, D. W. 1977. Evolution of phosphorus limitation in lakes. Science 195:260-262.

Schindler, D. W. 1989. Experimental perturbations of whole lakes as tests of hypotheses concerning ecosystem structure and function. Oikos 57:2541.

Steele, J. H. 1989. The ocean 'landscape'. Landscape Ecology 3:185-192

Stemberger, R. S. 1979. A guide to rotifers of the Laurentian Great Lakes.

EPA-600/4-79-021.

Stemberger, R. S., and J. J. Gilbert. 1985. Body size, food concentration, and population growth in planktonic rotifers. Ecology 66:1151-1159.

Thornton K. W., R. H. Kennedy, J. H. Carroll, W. W.
Walker, R. C. Gunkey, and S. Ashby. 1981. Reservoir sedimentation and water quality heuristic model. Proc. of a symposium on surface water impoundments, Am Soc. Civil Eng., Minneapolis, MN.

Wetzel, R. G. 1975. Limnology. W. B. Saunders \& Co. Philadelphia, PA.

Wetzel, R. G. and P. H. Rich 1973. Carbon in freshwater systems. In G. M. Woodwell and E. V. Pecan, eds. Carbon and the biosphere. Proc. Brookhaven Symp. in Biol. 24. Brookhaven Tech. Inf. Centr.

Wilde, E.W. 1985.Compliance of the Savannah River Plant P-Reactor Cooling system With Environmental Regulations. Demonstrations in Accordance With Sections 316(a) and (b) of the Federal Water Pollution Control Act of 1972. Report No. DP-1708. E.I. duPont de Nemours and Company, Savannah River Laboratory, Aiken SC. 


\title{
SYNOPTIC SURVEYS OF MAJOR RESERVOIRS \\ IN SOUTH CAROLINA, 1988-1989 (U)
}

\author{
APPENDIX: RESERVOIR SAMPLING STATIONS
}




\section{SEMICONTINUOUS TRANSECTS 30-50 SAMPLES AT 1 METER DEPTH}

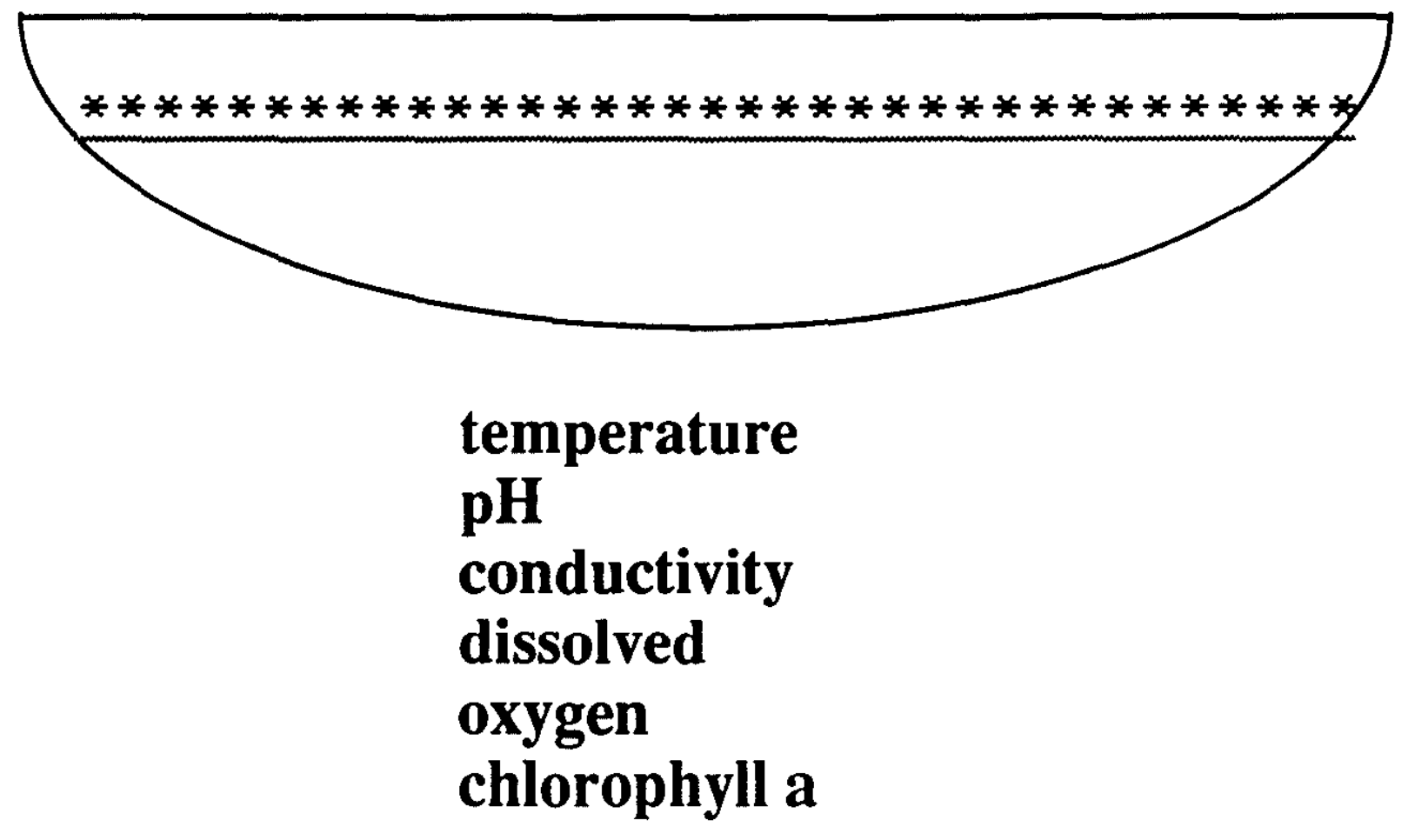

Figure 1.Transect sampling design along the longitudinal axis of each basin. 


\section{SAMPLING APPARATUS for LAKE TRANSECTS}

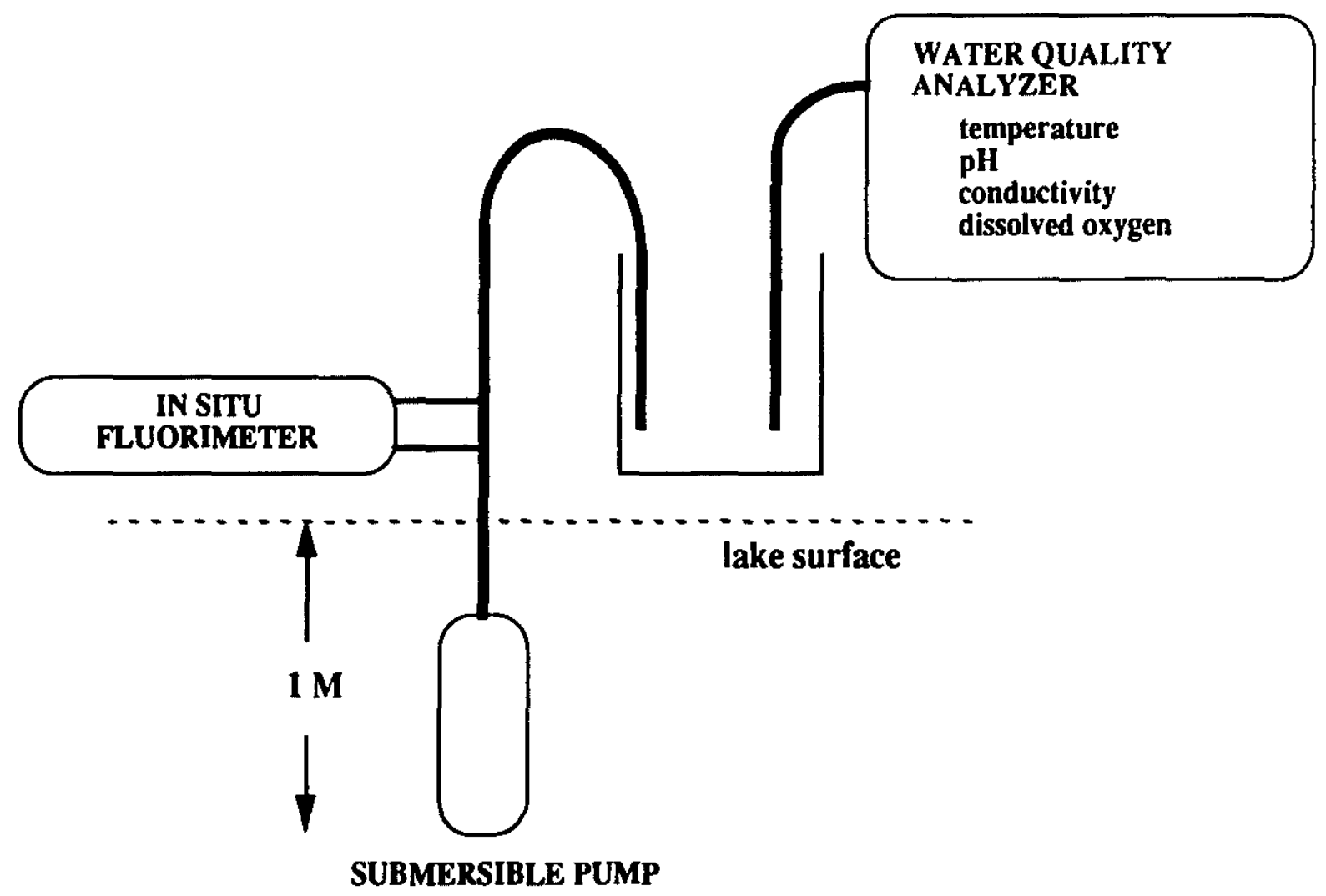

Figure 2. Pump sampling system for transect collections. 
SINGLE DEPTH (1 M)

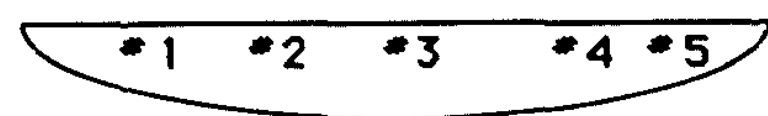

Secchi disk

alkalinity

total P

total inorganic $\mathbf{N}$

turbidity

DOC
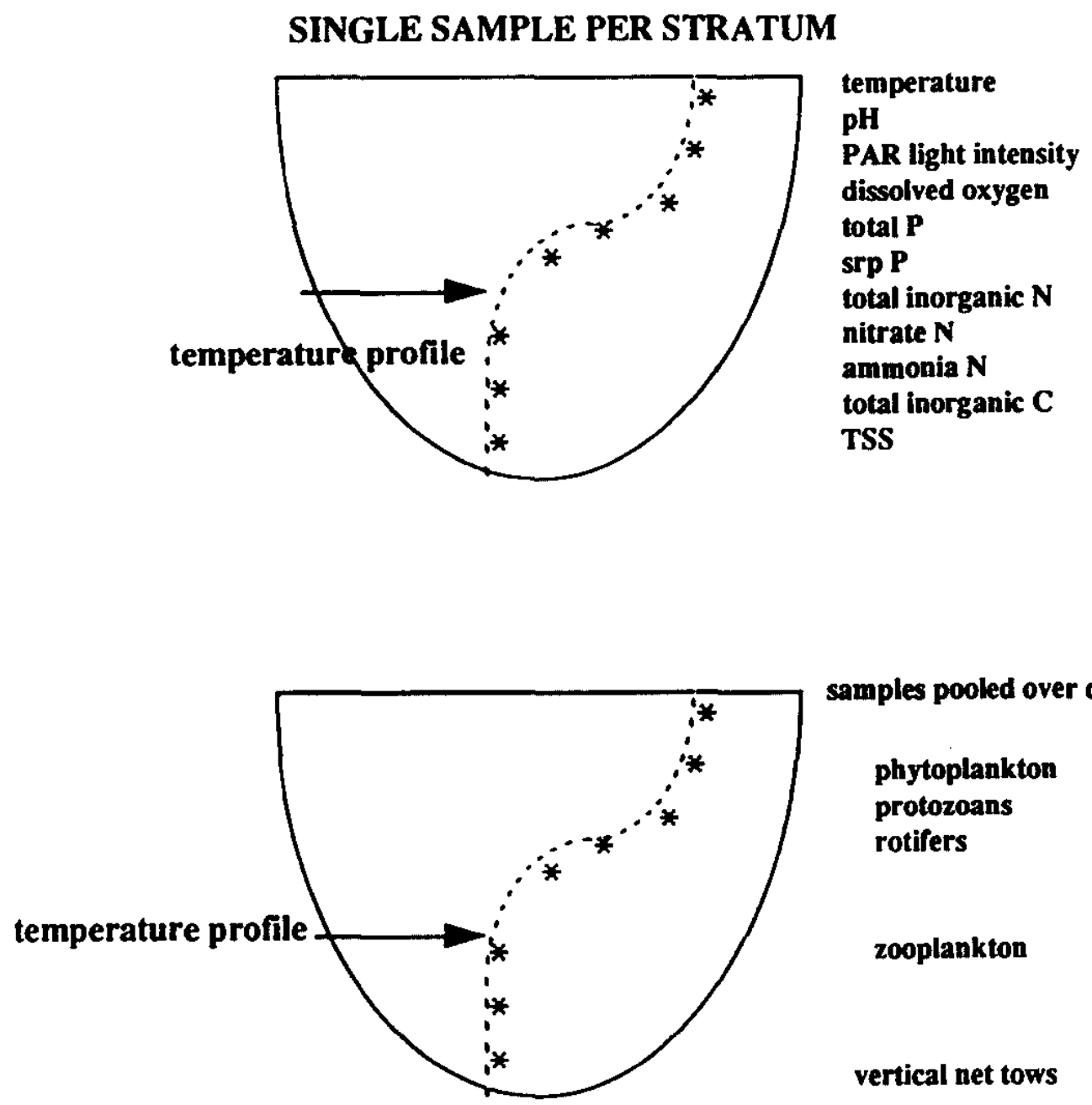

samples pooled over depth

phytoplankton

protozoans

rotifers

zooplankton

vertical net tows

Figure 3. Depth distributions for sampling at each station. 


\section{INSHORE BENTHIC SAMPLING STATIONS}

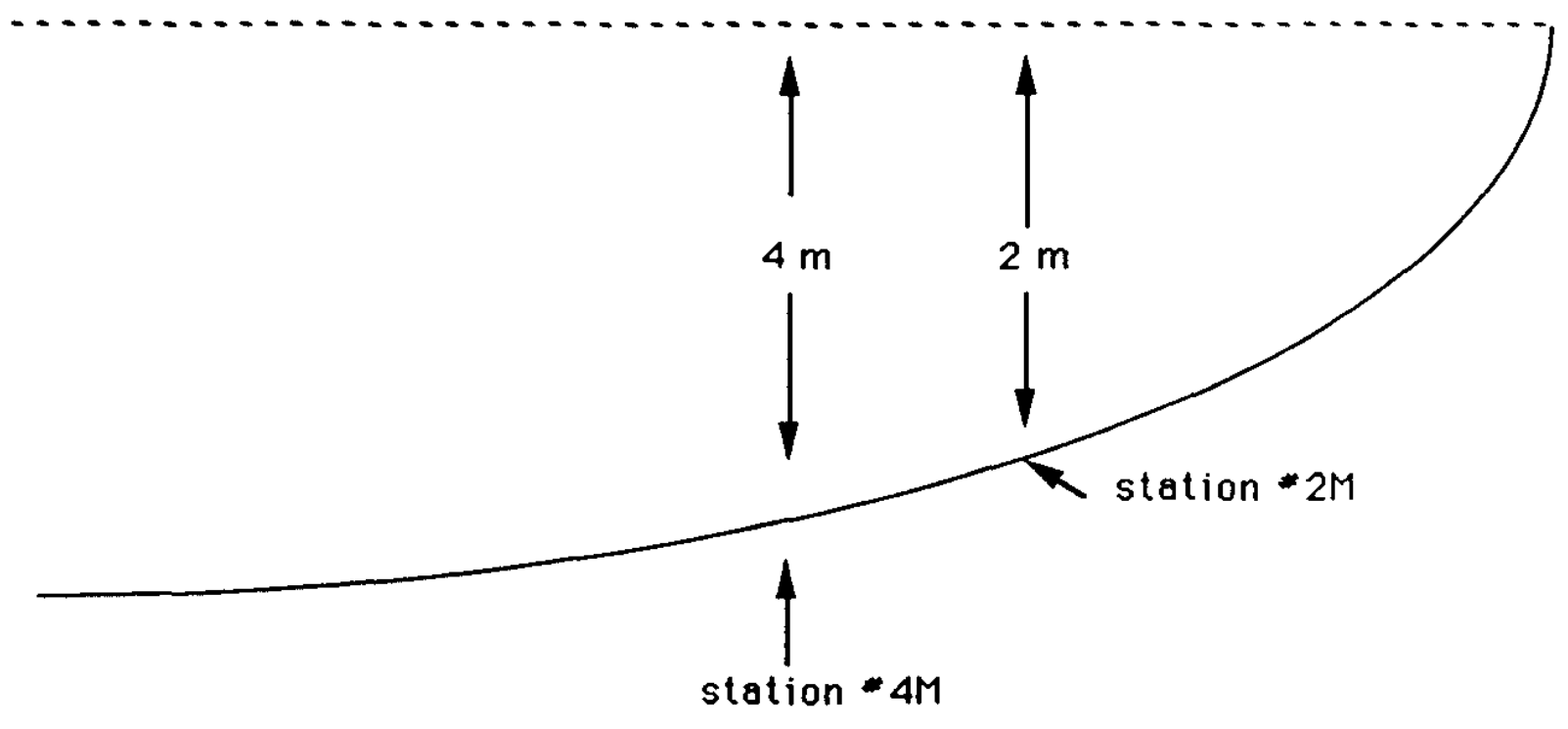

Figure 4. Sampling protocol for PONAR grabs. 


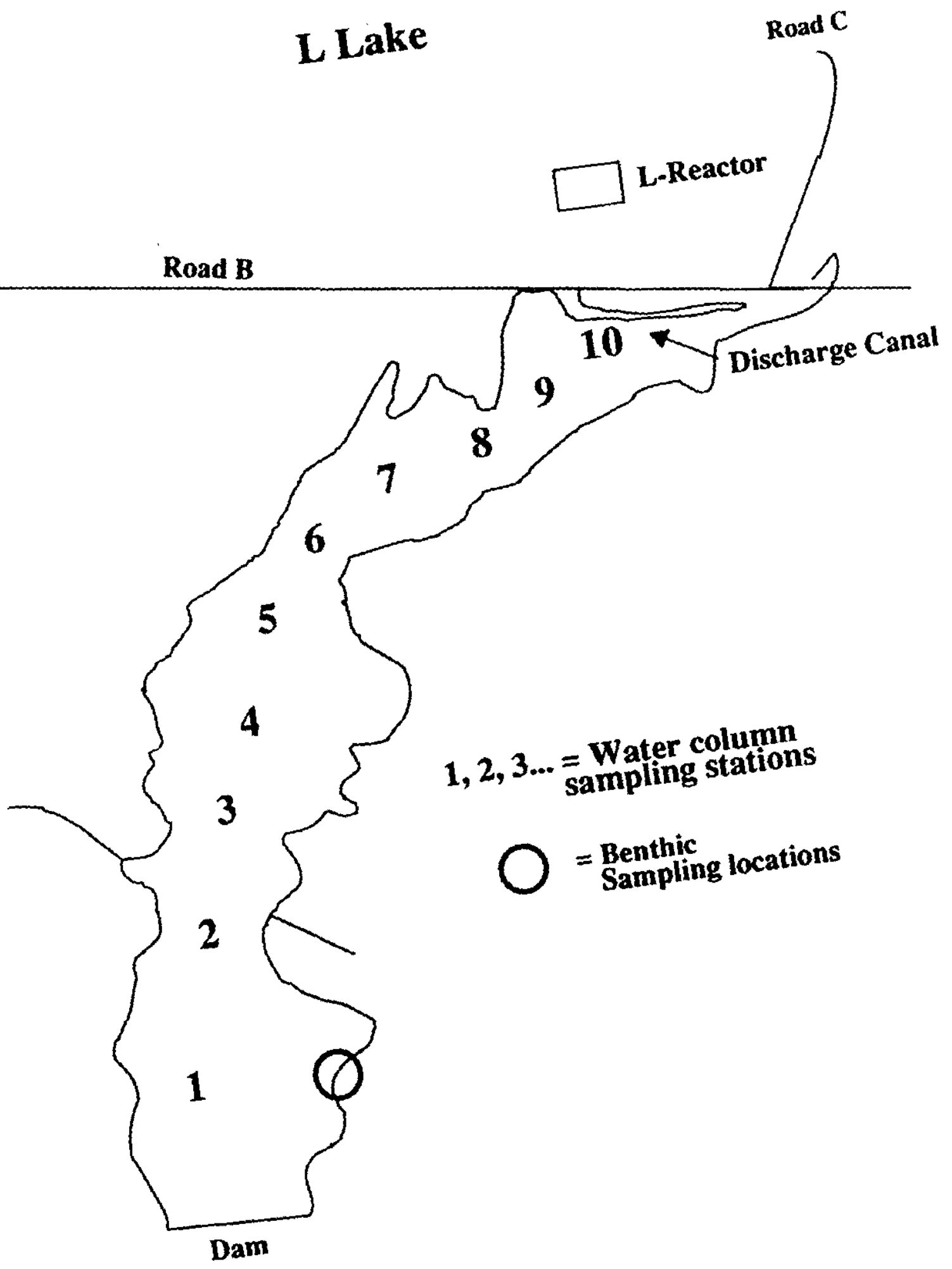

Figure 5. Sampling stations in L Lake. 


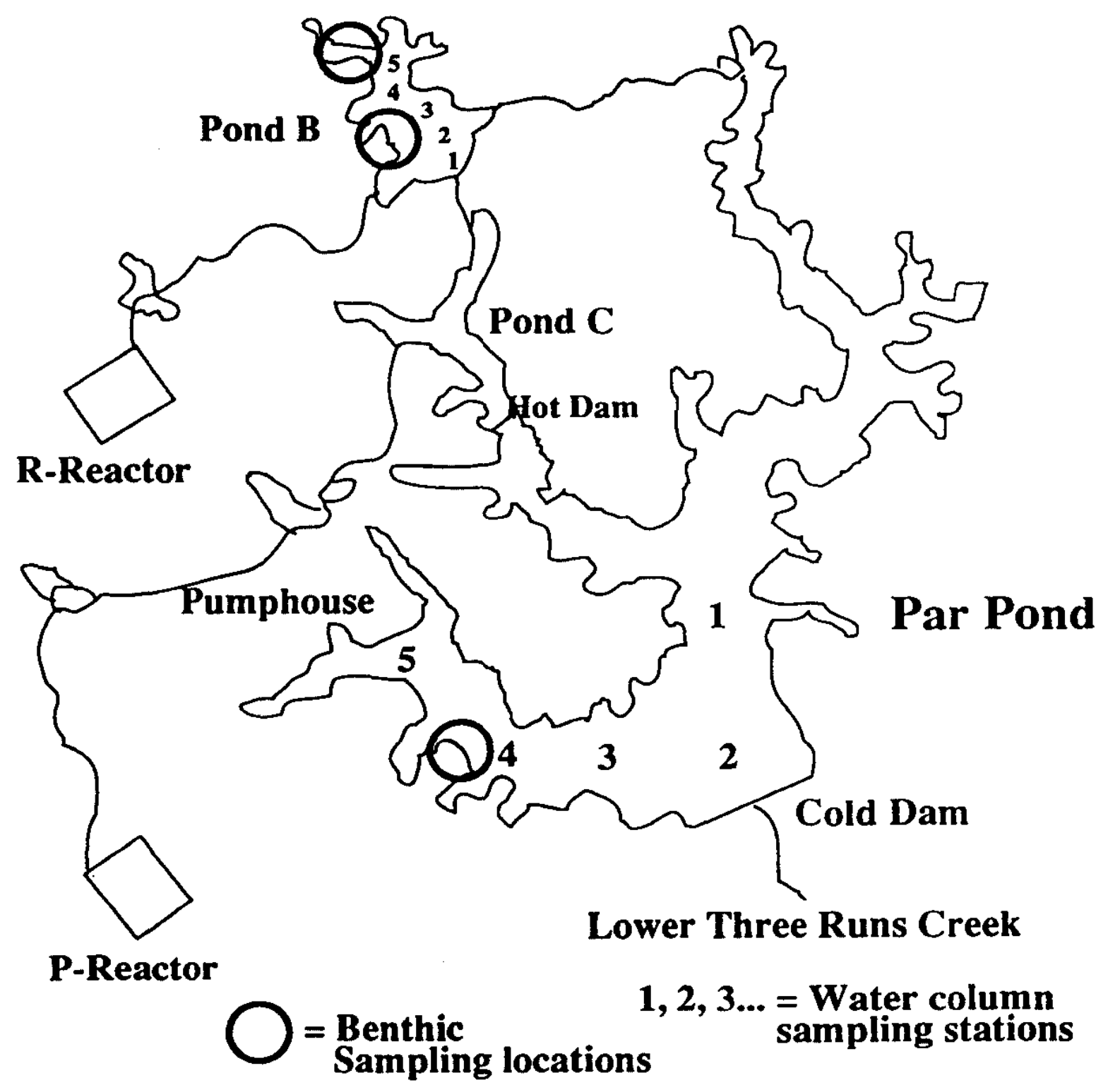

Figure 6. Sampling stations for Par Pond and Pond B. 


\section{Lake Greenwood}

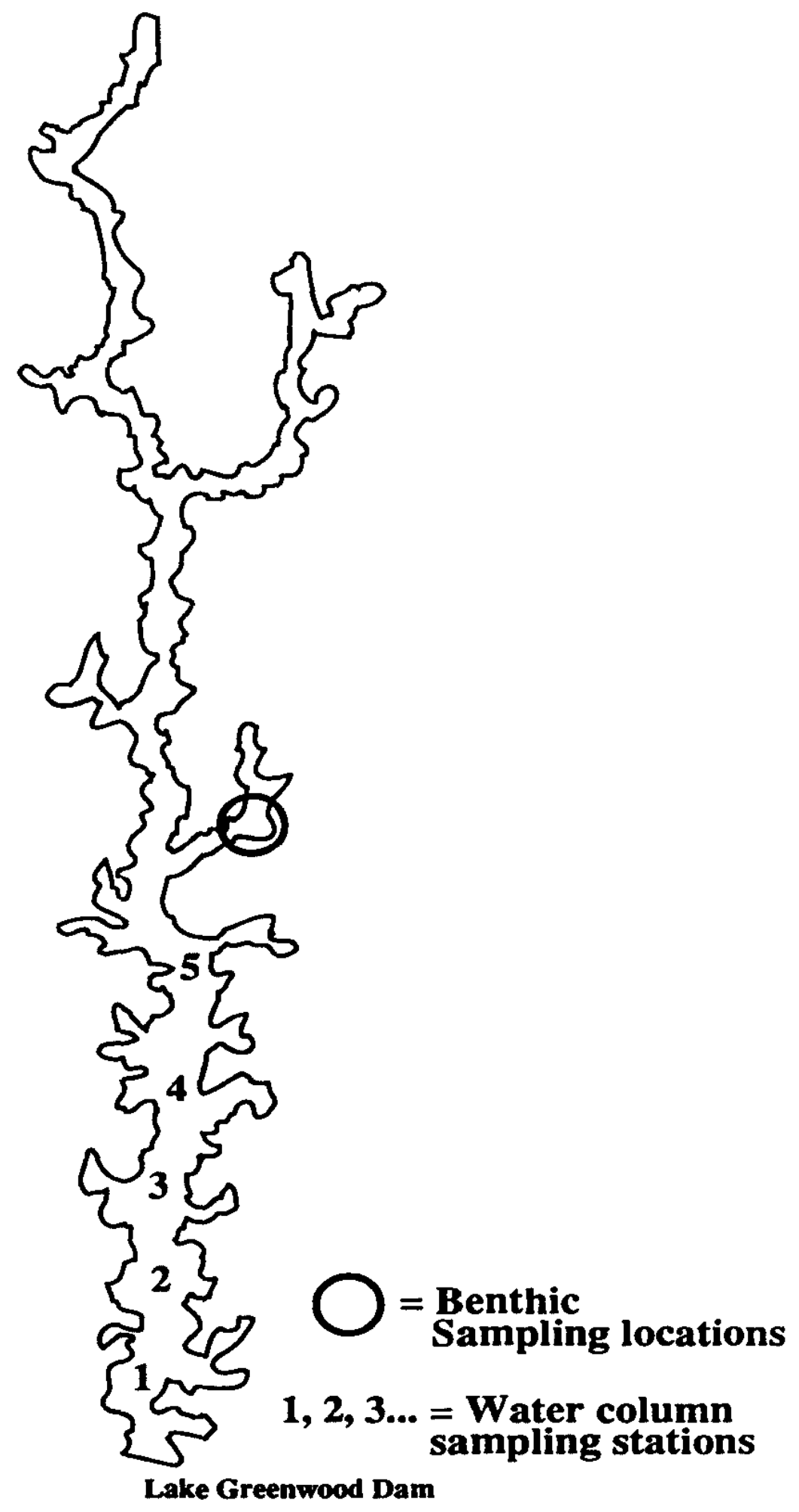

Figure 7. Sampling stations in Lake Greenwood. 


\section{Lake Murray}

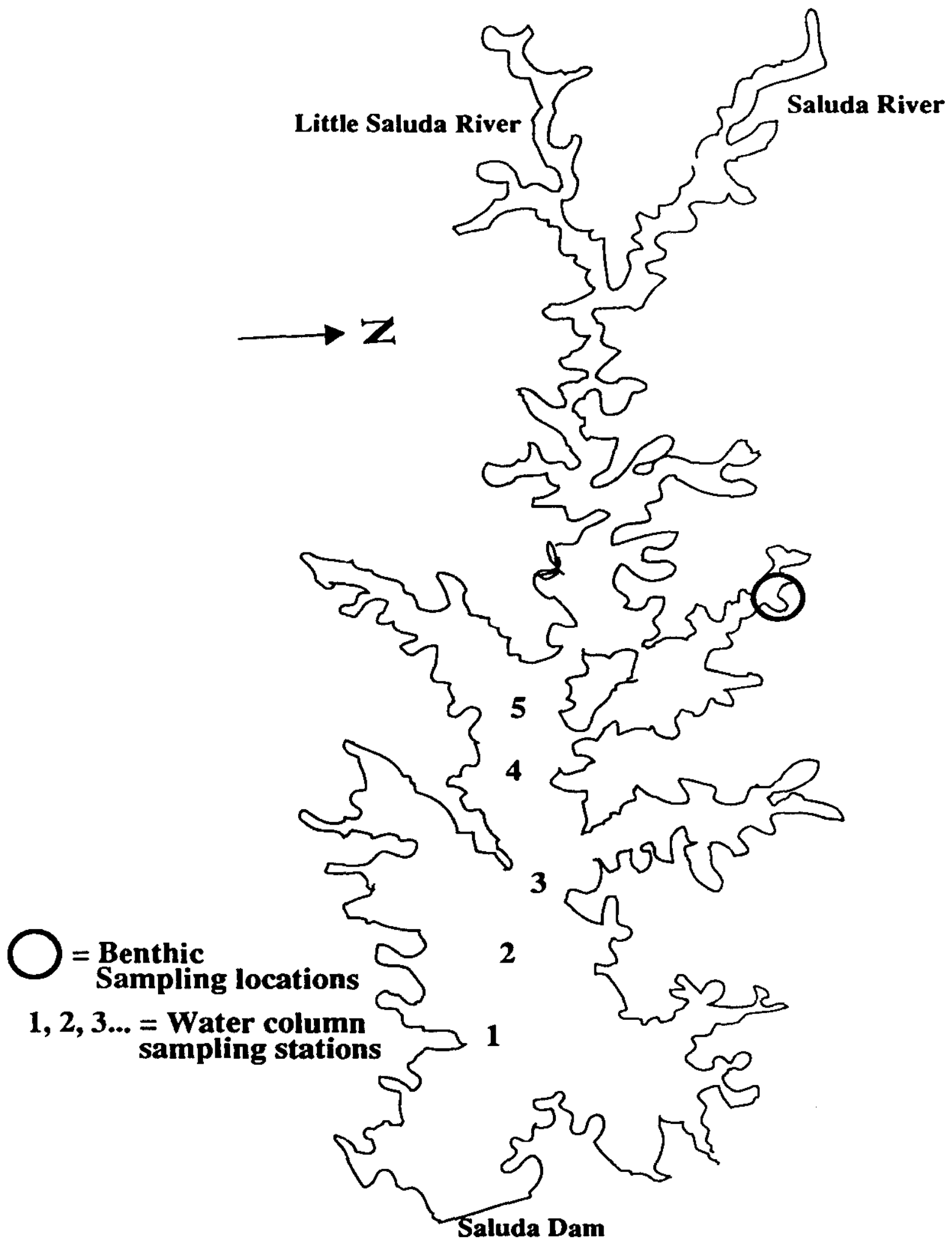

Figure 8. Sampling stations in Lake Murray. 


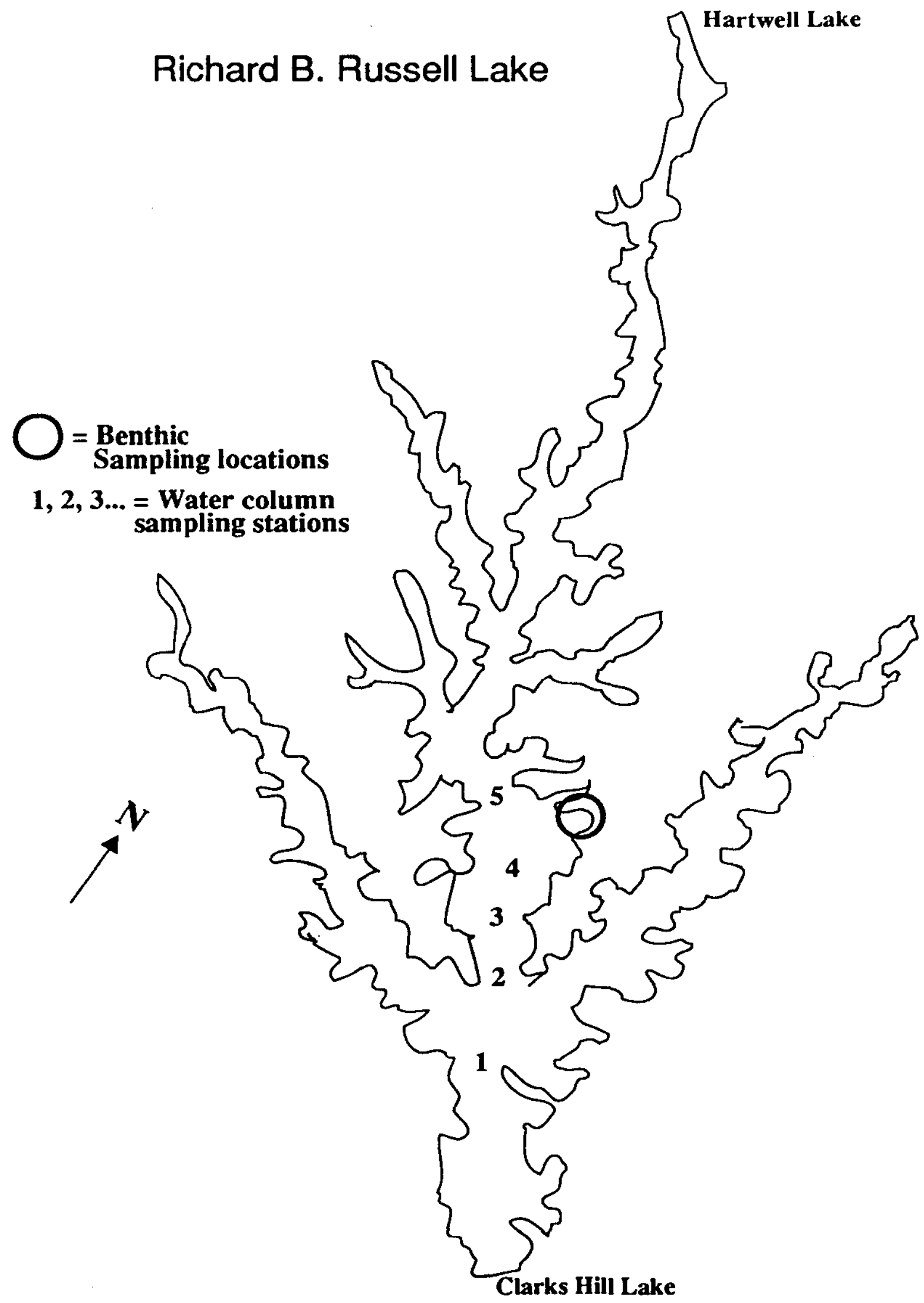

Figure 9. Sampling stations in Lake Russell. 


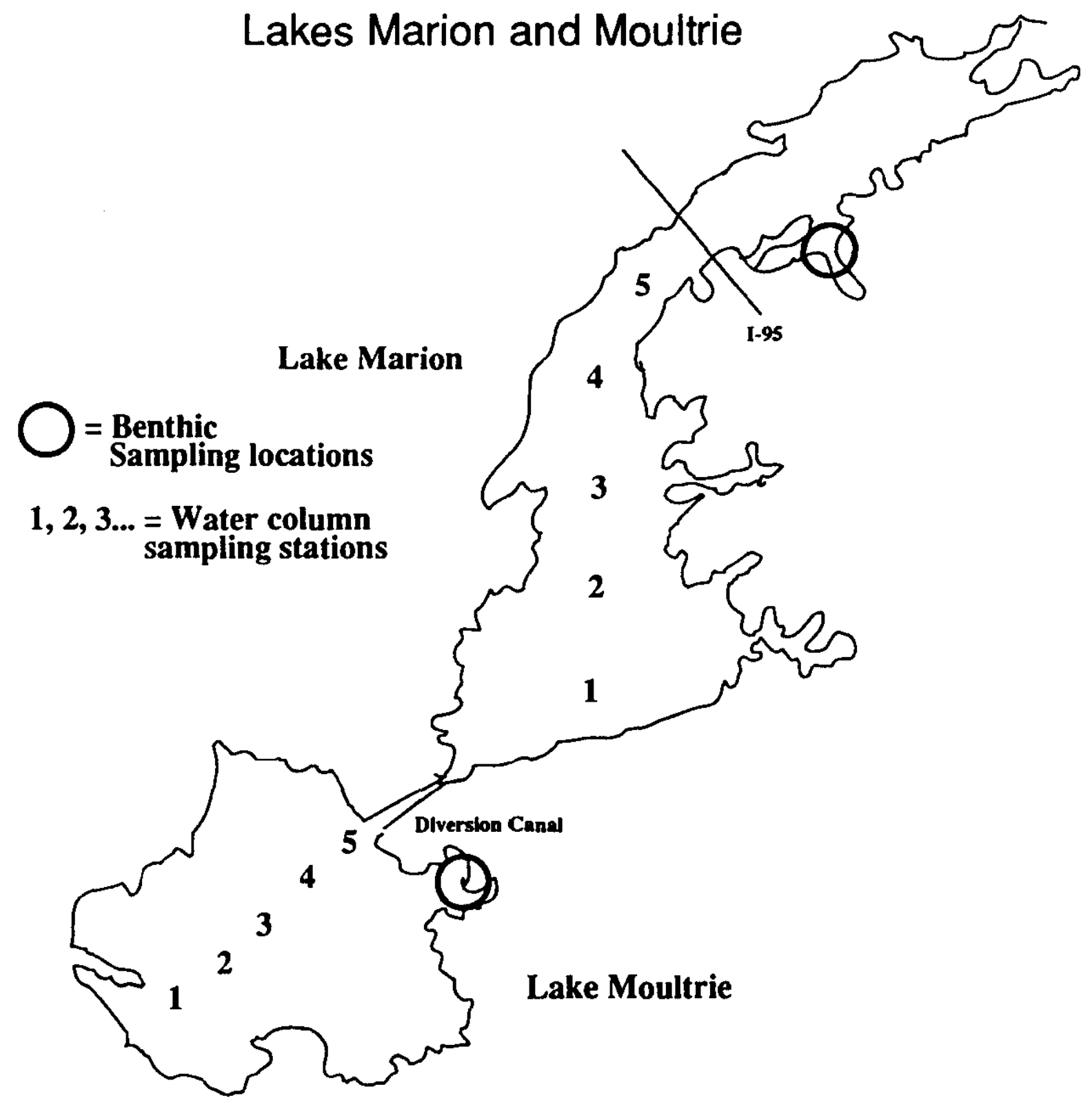

Figure 10. Sampling stations in Lakes Marion and Moultrie. 


\section{Lake Robinson}

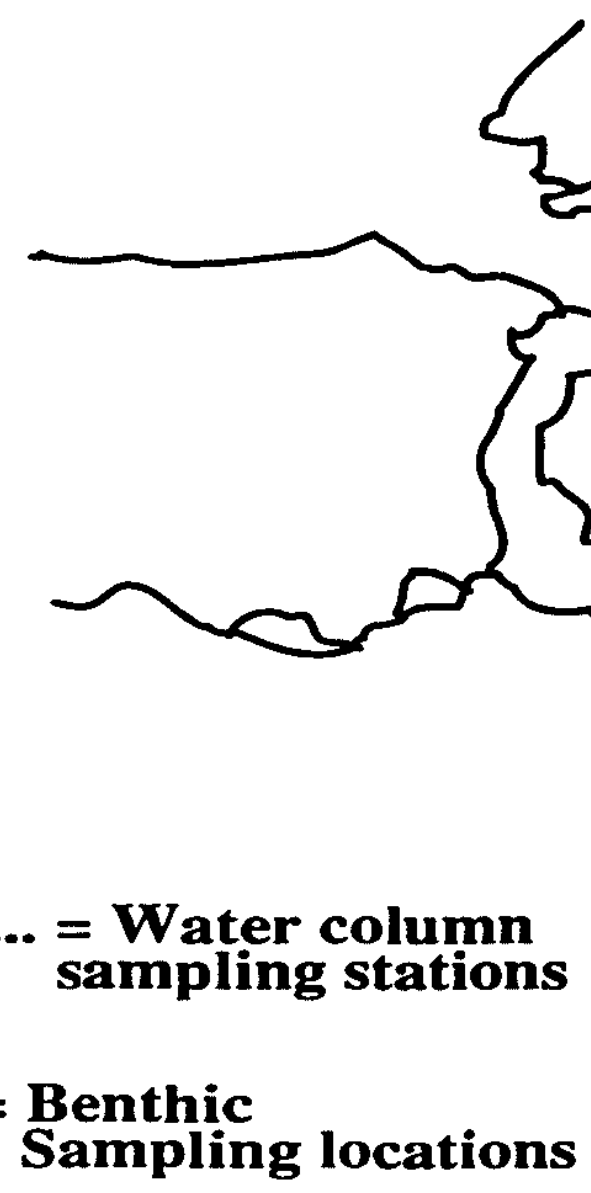

$1,2,3 \ldots .=\underset{\text { Wampler column }}{\text { Watations }}$

$\bigcirc=\begin{aligned} & \text { Benthic } \\ & \text { Sampling locations }\end{aligned}$
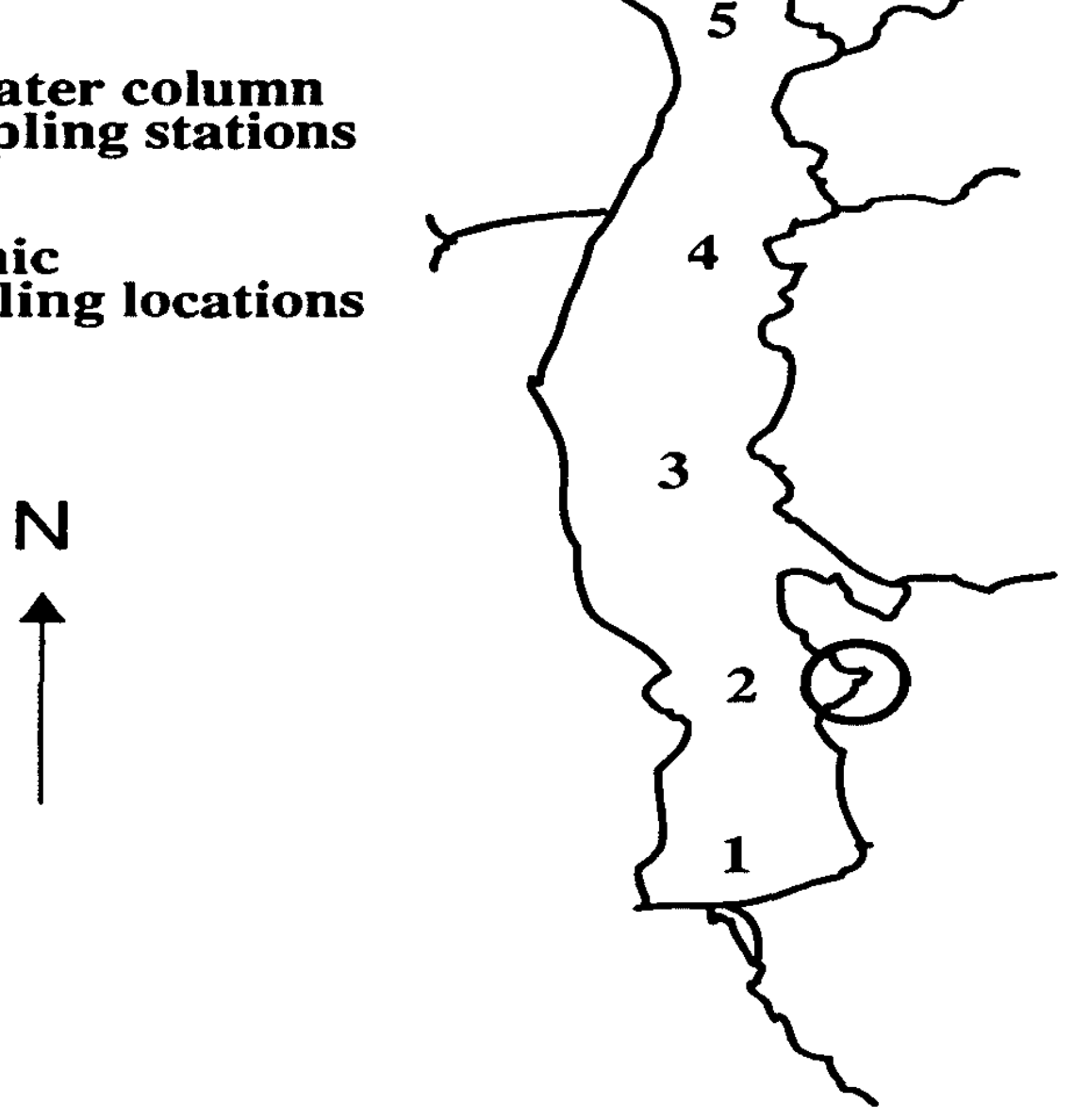

Figure 11. Sampling stations in Lake Robinson. 


\section{Lake Monticello}

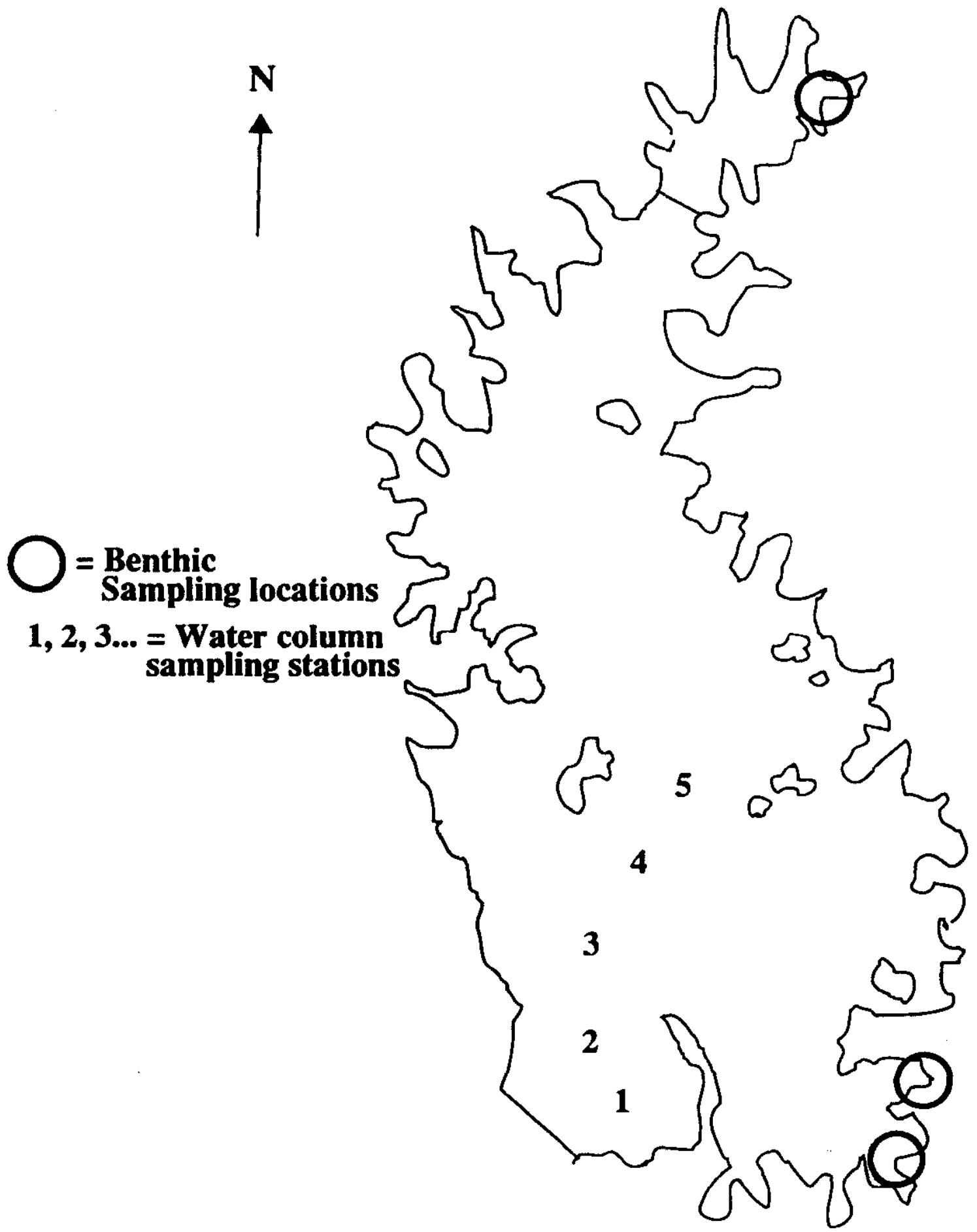

Figure 12. Sampling stations in Lake Monticello. 
June 29, 1992

ASD-TIM-92-795

Mr. Harold M. Dixon, Patent Counsel

U. S. Department of Energy

Savannah River Operations Office

Building 719-5A

Aiken, South Carolina 29802

Dear Mr. Dixon:

\section{BEQUESTFORPATENT REVIEW}

Please review for patent considerations:

\section{DETALS OF REOUEST FOR BELEASE}

Document No.

WSRC-RP-92-368

Author

J. A. Bowers

Title: "SYNOPTIC SURVEYS OF MANOR RESERVOIRS IN SOUTH CAROLINA. 1988-1989 (U)"

A technical deliverable being deposited to OSTI for unlimited distribution to the general public. If you decide to pursue a patent on any development covered, I shall be happy to supply additional information required such as appropriate references and the names of persons responsible for the development. The document has not been reveiwed for patent considerations by WSRC, as that function is not in place at this time. Please be advised that this document will be released within two weeks of the above date. If any clarification is needed, you may call me at 5-3992.

Very truly yours,

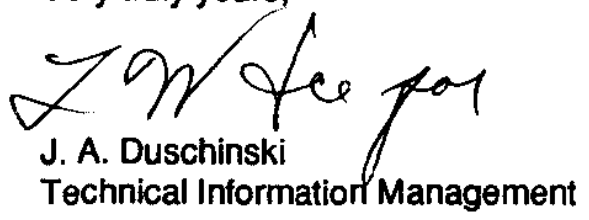

The above document has been reviewed for patent considerations and is approved for release.
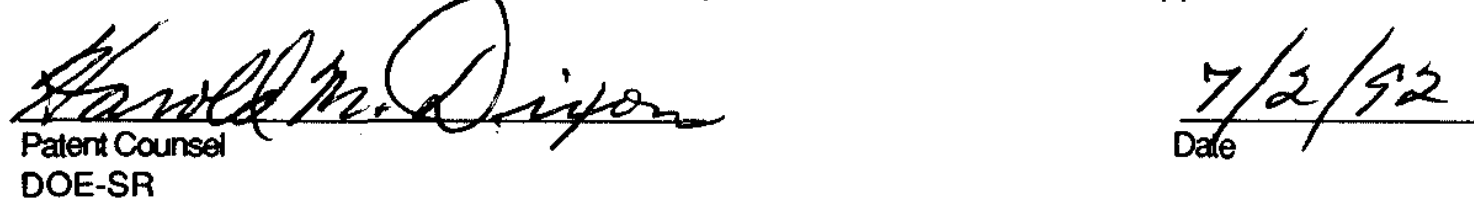

JAD/mag 
Ms. W. F. Perrin, Technical Information Officer

U. S. Department of Energy

Savannah River Operations Office

Aiken, SC 29801

Dear Ms. Perrin:

\section{REQUEST FOR APPROVAL TO RELEASE SCIENTIFIC/TECHNICAL INFORMATION}

The attached document is submitted for classification and technical approvals for the purpose of external release. Please complete Part II of this letter and return the letter to the undersigned by Alg 10,1992. Patent clearance, if necessary, is requested and received via direct communications between this office and the DOE-SR Patent Counsel. The document has been reviewed for classification by a WSRC classification staff member and has been deteremined to be unclassified/UCNI.

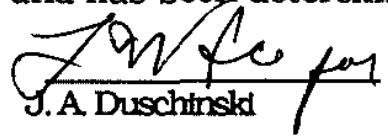

WSRC Technical Information Manager

\section{DETAILS OF REQUEST FOR RELEASE}

Document No. WSRC-RP-92-368

Author's Name J.A. Bowers 13 Address 773-42A

Document Title "SYNOPTIC SURVEYS OF MAJOR RESERVOIRS IN SOUTH CAROLINA. 1988-1989 (U)"

A technical deliverable being deposited to OSTI for unlimited distribution to the general public. Technical questions pertaining to the contents of this document should be addressed to the author(s) or __ D. B. Moore-Shedrow Manager of Environmental_Sciences_Section_-., Savannah River Site.

Questions concerning the processing of this document should be addressed to the WSRC Technical Information Manager, 5-3992 or 5-2646.

II. DOE-SRACTION

$\square$ Approved

Approved Upon Completion of Changes $\square$ Revise and Resubmit to DOE-SR

$\square$ Approved with Remarks

Remarks:

See editorial comments on title page, also on pages 2 and 39 . 
1. DOE Report No. WSRC-RP-92-368

2. DOE Contract No.

DEAC0989SR18035

5. TH1 "SYNOPTIC SURVEYS OF MAJOR RESERVOIRS IN SOUTH CAROLINA, 1988-1989 (U)"

4. OSTI UC or C Category No. UC-702

\section{Type of Document ("x" one)}

a. Scientific and technical report: $\square$ monthly $\square$ quarterly $\square$ annual $\square$ final $\square$ topical $\square$ special/public interest $\otimes$ other

b. Conference paper: Name of conference (no abbreviations)

Location (city/st/ctry)

Date (mo/day/yr)

Contents: $\square$ proceedings $\square$ viewgraphs $\square$ paper $\square$ poster sessions

c. Computer Media:

Document is accompanied by $\square$ magnetic tape (s)

$\square$ diskette (s)

$\square$ other (specify)

d. Other (e.g., journal article, manuscript, manual, etc.) (specify)
J. A. Bowers

7. Coples Transmitted to OSTI ("x" one or more). See instructlons on Reverse.

$\square$ a. Copies for unclassified distribution.

b. Twelve copies for OSTI processing and NTIS sales.

c. Twenty-five additional copies for special/public interest.

$\triangle$ d. Two reproducible copies for OSTI processing. $\square$ e. Copies for special distribution.

1. Copies for classified distribution as defined in $\mathrm{M}-3679$.

$\square$ g. One copy for OSTI classified processing.

8. Document contains information pertaining to any of the following:

$\square$ Yes (" $x$ " one or more) $\square$ No (If no, untimited distribution may be made within the U.S. In addition, copies may be made available to

a. Classified foreign requestors through exchange agreements of NTIS sales.)

(Announce to appropriate recipients as listed in M-3679, "Standard Distribution for Classified Scientific and Technical Reports")

b. Expon Control/TAR/EAR

c. Proprietary Data

d. Smalt Business Innovation Research (SBIR)

e. Unclassified Controlled Nuclear information (UCNI)

f. Patent Hold

g. Translations of copyrighted material

(Boxes b-g will be announced to Government agencies and their contractors)

h. Cooperative Research and Development Agreement (CRADA)

i. Other (explain)

(This designation must be in accordance with written DOE Program Office guidance. Attach copy of guidance.)

Upon demand, OSTI will make distribution of these documents in accordance with existing laws, regulations, and/or written program office quidance.

\section{Patent Information}

a. Does this information product disclose and new equipment, process, or material? $\otimes$ No $\square$ Yes if so, identify page nos.

b. Has an invention disclosure been submitted to DOE covering any aspect of this information product? $\square$ No $\square$ Yes If so, identify the DOE (or other) disclosure number and to whom the disclosure was submitted.

c. Are there any patent-related objections to the release of this information product? $\triangle$ No $\square$ Yes If so, state these objections.

10. Additional information, remarks, and special handling instructlons. (Do not identify Sigme categorles for Nuclear Weapon Data reports, and do not provide additlonal instructions which are inconsistent with item 8 above.) (Continue on separate sheet, If necessary.)

Other Authors:

11. Submitted by (Name and Position) (Please print or type) Jack Dushinski
Phone

FTS 239-3992
Organization

TIM 
1. DESCRIPTION OF DOCUMENT (to be completed by author)

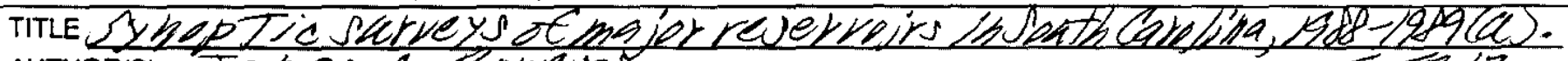
AUTHOR(S) Jahes A. Bumers

TYPE: $\square$ INTERNAL DOCUMENT PHONE NO. $5-5 \geqslant / 3$

D EXTERNAL DOCUMENT

ॠ DP Report (PP)

$\square$ Paper (see bolow)

$\square$ Other

\section{Additional Information for External Papers}

PAPER FOR: Presentation Only

Publication Only

Both

MEETING NAME

CITY

CHAIRMAN \& ADDRESS

JOURNAL NAME

OEADLINES FOR PUBLICATION:

Abstract

I understand that for information in this paper intended for external distribution:
A. Approvals by both Du Pont and DOE-SR managements are required.
B. Distribution verbally, or by publication, must be in accordance with policies set fonth in DOE-SR orders.
C. Content of the extemal distribution must be limited to that actually apospved by DOE-SR.

No. of Copies

DATES

A. Approvals by both DU Pont and DOE-SR managements are required.

C. Content of the extemal distribution must be limited to that actually apgroved by DOE-SR.

AUTHOR'S SIGNATURE

2. APPROVAL BY AUTHOR'S ORGANIZATION (required for all technicatobcuments)

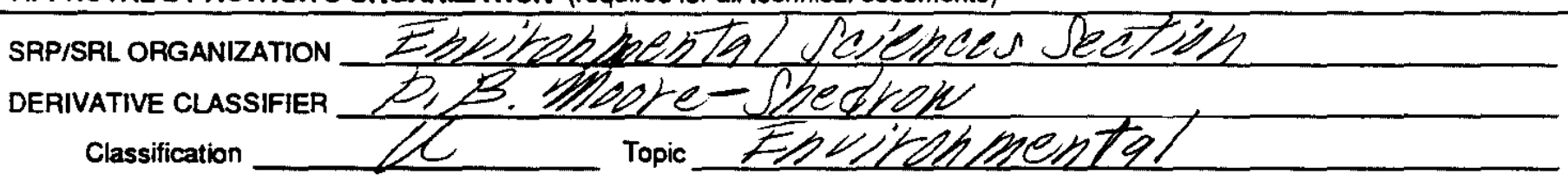

DISTRIBUTION

Limit to List Attached. Reason:

_ Limit to DOE-SR \& Du Pont Contractual Family. Reason :

$><$

Site-Specific Procedure, Data Sheet, TA, etc.

Unlimited To General Public

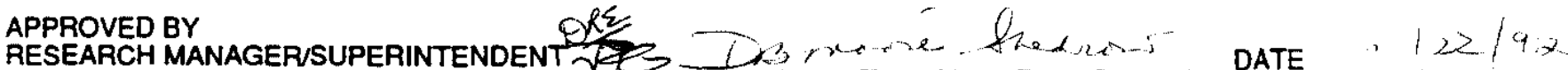

3. CLASSIFICATION \& PATENT INFORMATION (to be completed by Patent \& Classification Reviewer)

CLASSIFICATION (circie one for each)

Overali $\quad \mathrm{C}$ UNCI U

Abstract $\quad \mathrm{S}$ C UNCl U

Title S C UNCl $y$

Cover Letter wSאc C UNCI U APPROVED BYAEY PATIAT

CLASSIFICATION OFFICER
CLASSIFICATION GUIDE TOPICS $C G-D A R-1$

Topie 2.2

PATENT CONSIDERATIONS

Possible Novel Features

Closest Prior Art

DATE $6 / 26 / 92$

4. PUBLICATIONS DIVISION PROCESSIÝG

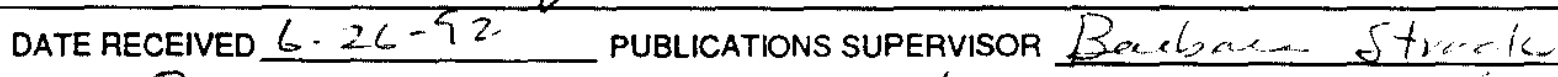

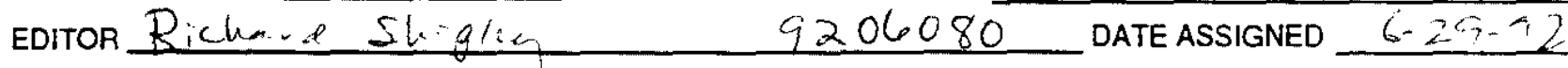
DATE COPIES SUBMITTED FOR RELEASE

DOE-SR RELEASE DATES: Patent Branch Tech. Info. Otfice

DATE COMPLETED DATE SUBMITTED TO OSTI 


\section{RECORD INDEXING}

Required with all document record copies sent to SSD/ISD.

Call 5-2494 for assistance as needed. 402417

Incomplete or incorrect forms will be returned to originator with record for review and correction.

Technical documents may also require OSR 14-357 Approval Sheet PRINT or TYPE IN BLACK INK

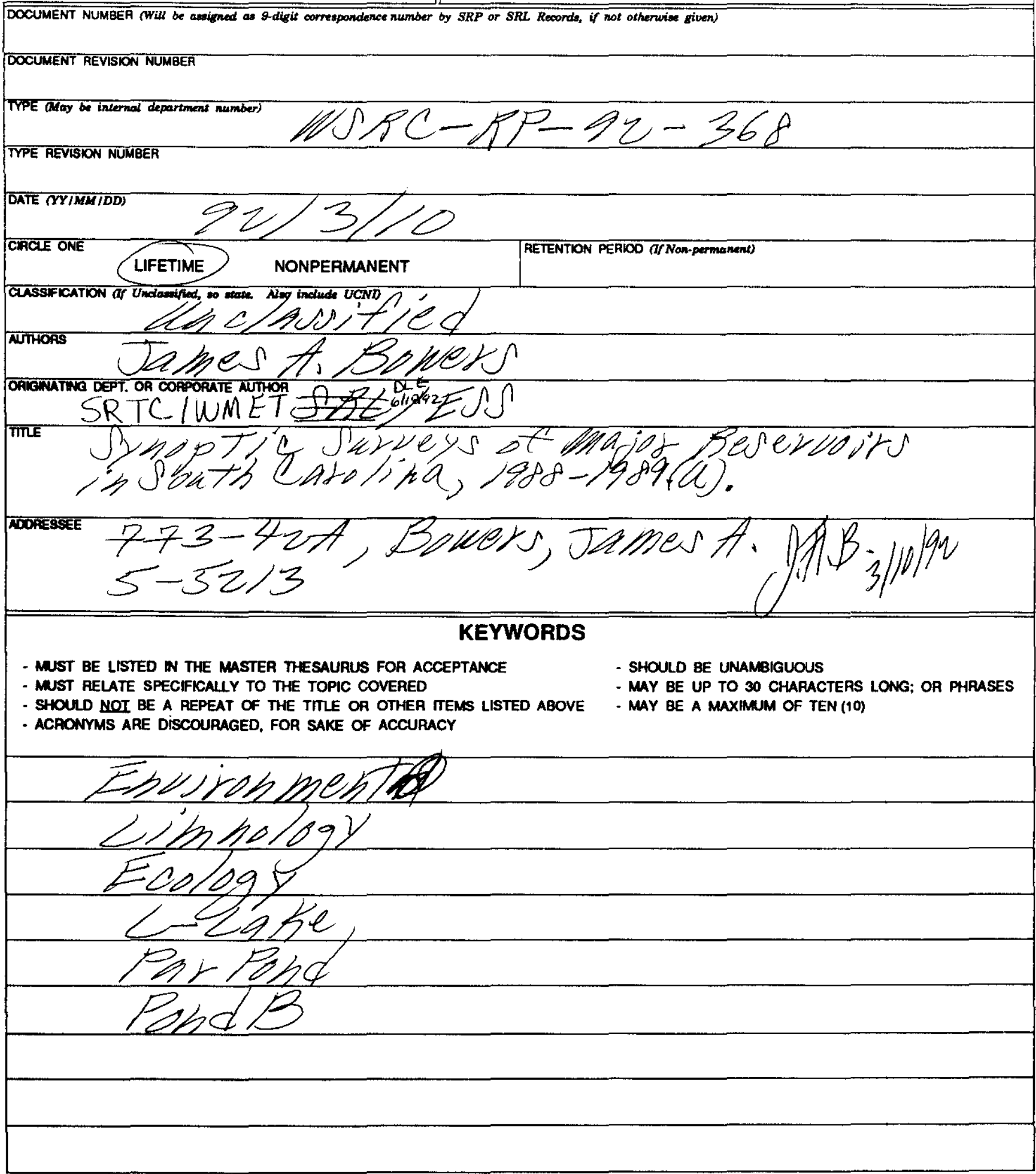

